University of Windsor

Scholarship at UWindsor

$11-7-2015$

\title{
Geochemistry, Nd, Pb and Sr Isotope Systematics, and U-Pb zircon ages of the Neoarchean Bad Vermilion Lake Greenstone Belt and Spatially Associated Granitic rocks, Western Superior Province, Canada
}

Tuoyu Wu

University of Windsor

Follow this and additional works at: https://scholar.uwindsor.ca/etd

\section{Recommended Citation}

Wu, Tuoyu, "Geochemistry, Nd, Pb and Sr Isotope Systematics, and U-Pb zircon ages of the Neoarchean Bad Vermilion Lake Greenstone Belt and Spatially Associated Granitic rocks, Western Superior Province, Canada" (2015). Electronic Theses and Dissertations. 5518.

https://scholar.uwindsor.ca/etd/5518

This online database contains the full-text of PhD dissertations and Masters' theses of University of Windsor students from 1954 forward. These documents are made available for personal study and research purposes only, in accordance with the Canadian Copyright Act and the Creative Commons license-CC BY-NC-ND (Attribution, Non-Commercial, No Derivative Works). Under this license, works must always be attributed to the copyright holder (original author), cannot be used for any commercial purposes, and may not be altered. Any other use would require the permission of the copyright holder. Students may inquire about withdrawing their dissertation and/or thesis from this database. For additional inquiries, please contact the repository administrator via email (scholarship@uwindsor.ca) or by telephone at 519-253-3000ext. 3208. 
Geochemistry, Nd, Pb and Sr Isotope Systematics, and U-Pb zircon ages of the Neoarchean Bad Vermilion Lake Greenstone Belt and Spatially Associated Granitic rocks, Western Superior Province, Canada

By

Tuoyu $\mathrm{Wu}$

\begin{abstract}
A Thesis
Submitted to the Faculty of Graduate Studies through the Department of Earth and Environmental Sciences in Partial Fulfillment of the Requirements for the Degree of Master of Science at the University of Windsor
\end{abstract}

Windsor, Ontario, Canada 
Geochemistry, Nd, Pb and Sr Isotope Systematics, and U-Pb zircon ages of the Neoarchean Bad Vermilion Lake Greenstone Belt and Spatially Associated Granitic rocks, Western Superior Province, Canada

By

Tuoyu Wu

APPROVED BY:

\begin{abstract}
Dr. K. Tepe
Department of Electrical and Computer Engineering
\end{abstract}

Dr. J.E. Gagnon

Department of Earth and Environmental Sciences

Dr. A. Polat (Advisor)

Department of Earth and Environmental Sciences

August 28, 2015 


\section{Declaration of Co-Authorship/ Publication}

\section{Authorship Declaration}

This thesis is the product of integrated research on the Neoarchean Bad Vermilion Lake greenstone belt in the Superior Province of Canada. Field work was conducted by Dr. Ali Polat. I carried out the laboratory analyses, data interpretation, and manuscripts preparation through cooperation with Dr. Polat and other co-authors. The contribution of other co-authors was primarily through review on the previous versions of the manuscript. Therefore, I certify that I am the major author of this thesis. Meanwhile, I declare that, to the best of my knowledge, my thesis does not infringe upon anyone's copyright nor violate any proprietary rights. All the ideas, techniques, quotations, material from the work of other people included in my thesis, published or otherwise, are fully acknowledged in accordance with the standard referencing practices.

\section{Declaration of Publication}

The thesis is based on an original paper that has been submitted for publication in Precambrian Research, which is an internationally renowned Earth Science journal. The percentage given by the author's name represent the relative scientific contribution of each co-author. Tuoyu Wu (55\%), Ali Polat (20\%), Robert Frei (10\%), Brian J. Fryer (5\%), Kunguang Yang (5\%), Timothy M. Kusky (5\%). 
All co-authors provided insightful critique on early versions of this manuscript. This study was possible through contributions of an NSERC grant to Ali Polat. Ali Polat conducted the field work and collected the samples, and provided guidance with the preparation of the manuscript. Robert Frei carried out the $\mathrm{Nd}, \mathrm{Pb}$ and $\mathrm{Sr}$ isotope analysis. Brian J. Fryer provided help with the ICP-MS trace element analyses. Kunguang Yang helped with U-Pb zircon dating at China University of Geosciences (Wuhan). Timothy Kusky provided insights with geodynamic interpretation of the Bad Vermilion Lake greenstone belt. Without their generous help, this study could not be accomplished; therefore, I am here to show my deepest gratitude to them. 


\begin{abstract}
The Neoarchean (ca. 2720 Ma) Bad Vermilion Lake (BVL) greenstone belt is composed of metamorphosed bimodal tholeiitic to calcalkaline basalts to rhyolites, volcaniclastic rocks, gabbros, and subordinate sedimentary rocks. All these rocks are intruded by granitic rocks.
\end{abstract}

The HFSE systematics of the volcanic and volcaniclastic rocks and gabbros are consistent with subduction zone geochemical signatures. The BVL greenstone belt is geochemically similar to Neoarchean subductionrelated ophiolites. Two rhyolite samples from the belt have been dated as $2724 \pm 23 \mathrm{Ma}$ and $2722 \pm 11 \mathrm{Ma}$, representing approximate age of the arc volcanism. The ca. 2664 Ma Ottertail Lake granite marks the end of tectonic accretion in the study area.

Both the volcanic rocks and gabbros show large ranges of $\mathrm{Nd}, \mathrm{Pb}$ and $\mathrm{Sr}$ isotopic compositions, reflecting post-magmatic alteration. $\mathrm{Pb}-\mathrm{Pb}$ regression ages of gabbros $(2725 \pm 83 \mathrm{Ma})$ agree with the $\mathrm{U}-\mathrm{Pb}$ ages of the rhyolites, suggesting that the $\mathrm{U}-\mathrm{Pb}$ system was the most robust isotopic systems.

Keywords: Archean greenstone belt, Superior Province, Western Wabigoon subprovince, Bad Vermilion Lake, Trace element, Radiogenic isotopes 


\section{Acknowledgements}

My sincerest thanks and gratitude must foremost be extended to Dr. Ali Polat for his patient mentorship, enthusiastic encouragement, and, most of all, his thorough, insightful, and constructive criticism-all of which have been generously provided over the course of the past two years. The other two professors, Dr. Joel Gagnon and Dr. Kemal Tepe, in my academic committee have inspired me to think critically in every aspect of life and have shown me the value of succinct, persuasive writing; I will likely spend the rest of my life trying to master these skills.

In addition, I have received lots of endorsement during the completion of my master project. For instance, Dr. Iain Samson offered me the opportunity to do the microscopic analyses in his lab; Dr. Lu Wang from China University of Geosciences (Wuhan) patiently taught me sample preparation and analytical techniques related to U-Pb zircon dating; Melissa Price and J.C. Barrette granted me guidance on trace element analyses using ICP-MS; Sharon Horne, Maria Stanko, and Margaret Mayer provided administrative services and logistic support during my study in the department; graduate peers such as Eyal Friedman and Shuda Zhou often shared some incisive ideas during the discussion of my research progress.

Last but not least, I am very grateful for my parents' vital support and encouragement during the pursuit of this degree. Without their care, 
my M.Sc. experience would not have been joyful and memorable. 


\section{Table of Contents}

Declaration of Co-Authorship/ Previous Publication .....................................................ii

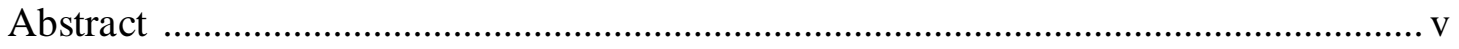

Acknowledgements ....................................................................................................... vi

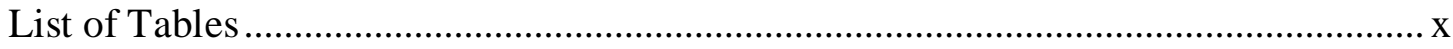

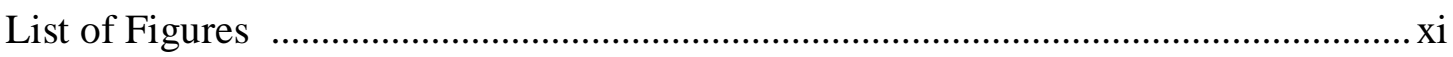

Chapter 1. Introduction

1.1. Backgrounds on Archean greenstone belts ...................................................... 1

1.2. Greenstone belts in the Superior Province ....................................................... 4

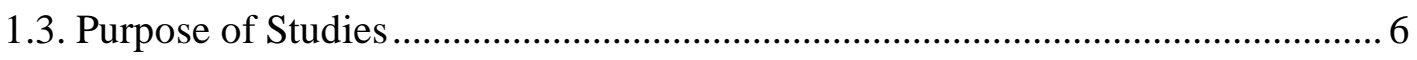

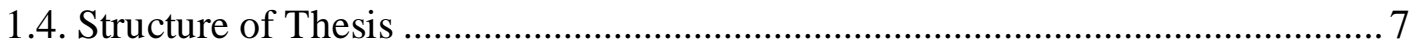

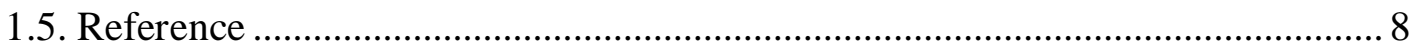

Chapter 2. Geochemistry, $\mathrm{Nd}, \mathrm{Pb}$ and $\mathrm{Sr}$ Isotope Systematics, and U-Pb zircon ages of the Neoarchean Bad Vermillion Lake Greenstone Belt and Spatially Associated Granitic rocks, Western Superior Province, Canada

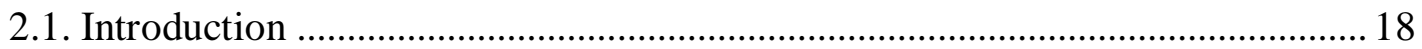

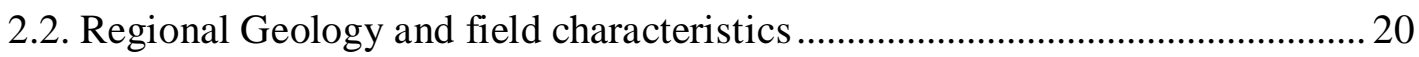

2.2.1. The Bad Vermilion Lake (BVL) greenstone belt........................................ 22

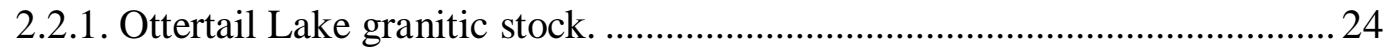

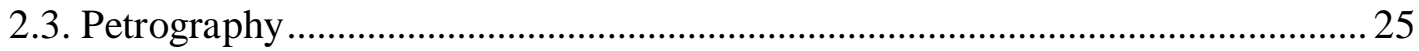

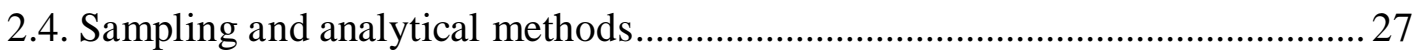

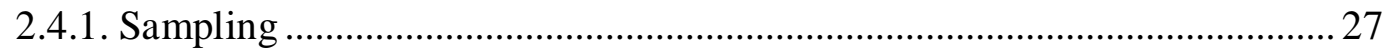

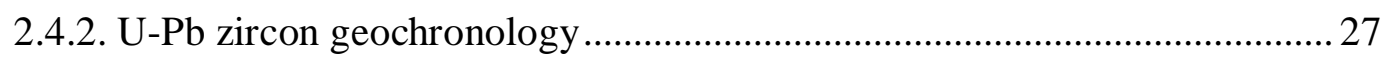

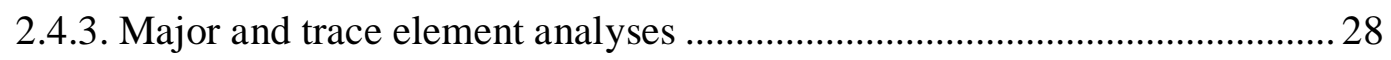

2.4.4. Sm-Nd, U-Th-Pb and $\mathrm{Sr}$ isotope analyses ................................................... 30

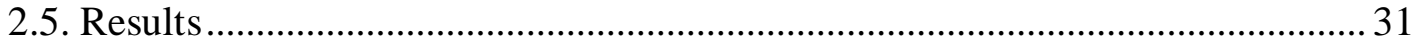

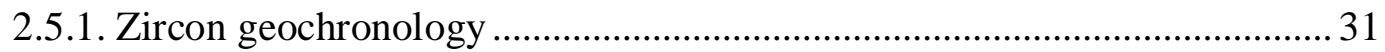

2.5.1.1. Rhyolite samples (BVL2013-030, BVL2013-031, and BVL2013-034)

2.5.1.2. Ottertail Lake granite sample (BVL2013-058) .................................... 33

2.5.2. Major and trace element analyses ................................................................. 33

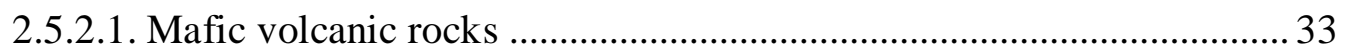

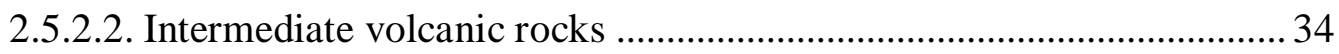


2.5.2.3. Intermediate to felsic volcaniclastic rocks ......................................... 35

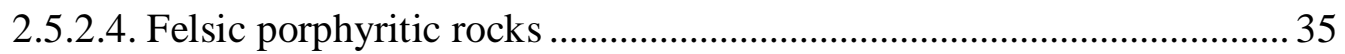

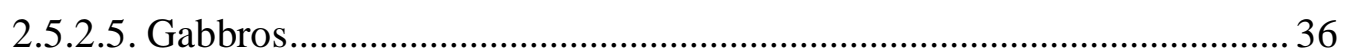

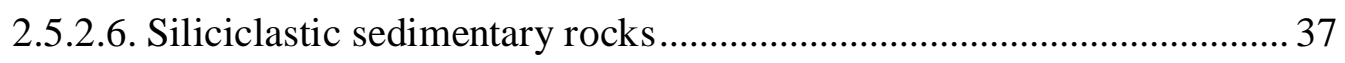

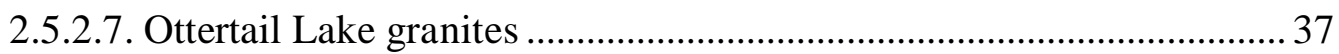

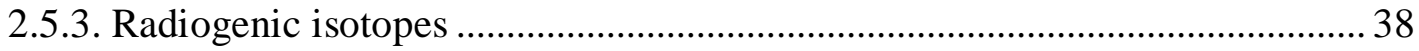

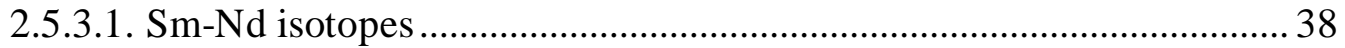

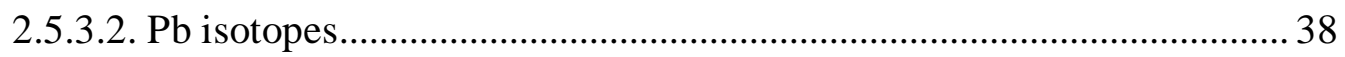

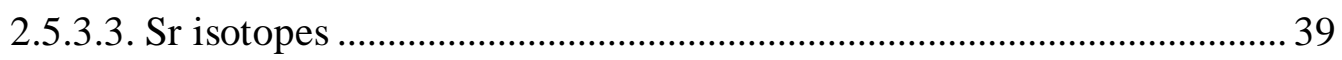

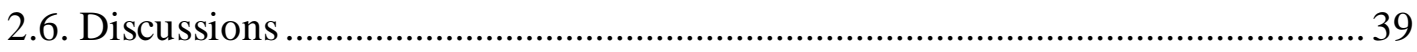

2.6.1. Effects of metamorphism on element mobility …......................................... 39

2.6.2. New age constraints and their implications .............................................. 41

2.6.3. Source characteristics and tectonic setting of the BVL greenstone belt .... 42

2.6.4. Source characteristics of the Ottertail Lake granite .................................... 44

2.6.5. Geodynamic and petrogenetic implications ............................................ 44

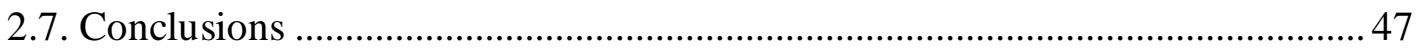

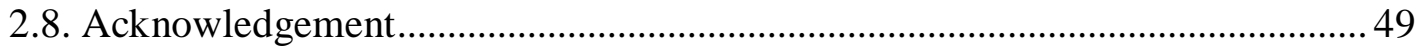

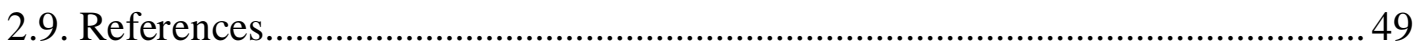

Chapter 3 Conclusions, Implications and Suggestions for future studies

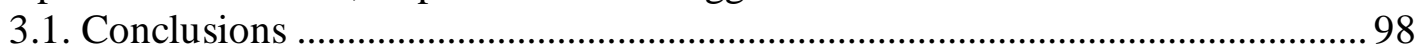

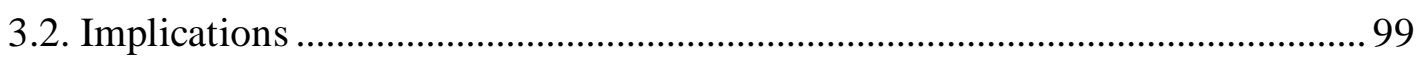

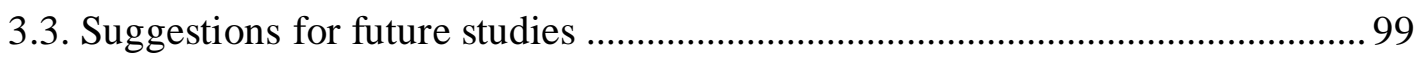

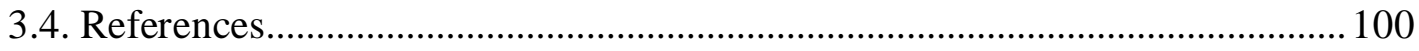

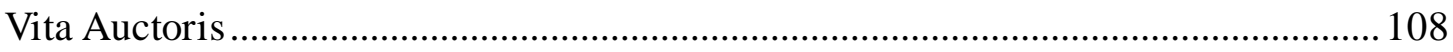




\section{List of Tables}

Table

2.1. Major (wt.\%) and trace (ppm) element concentrations and important element ratios for the Bad Vermilion Lake greenstone belt volcanic, volcaniclastic, and sedimentary rocks

2.2. Major (wt. \%) and trace (ppm) element concentrations and important element ratios for the Ottertail Lake granite.

2.3. Results of zircon $\mathrm{U}-\mathrm{Pb}$ isotope analyses

2.4. Sm-Nd isotope compositions of the volcanic rocks and gabbros in the Neoarchean Bad Vermillion Lake greenstone belt

2.5. $\mathrm{Pb}$ isotope compositions of the volcanic rocks and gabbros in the Neoarchean Bad Vermillion Lake greenstone belt

2.6. $\mathrm{Rb}$-Sr isotope compositions of the volcanic rocks and gabbros in the Neoarchean Bad Vermillion Lake greenstone belt 97

A.1. Standard samples for trace element analyses .................................................... 102

A.2. Measured element concentrations in analyzed zircons 103 


\section{List of Figures}

1.1. Global distribution of Archean crusts and underlain Precambrian basement

1.2. Simplified regional geological map of western Wabigoon subprovince, displaying major supracrustal belts (including plutons and greenstone belts) and structures

2.1. (a) Simplified tectonic map of the Superior Province (modified from Card and Ciesielski, 1986). (b) Regional geological map of the Rainy Lake area, Wabigoon subprovince, showing the location of the BVL greenstone belt and spatially related Ottertail Lake Stock and Bad Vermillion Lake anorthosite complex (modified from Blackburn et al., 1991)

2.2. Field photographs illustrating the lithological characteristics and field relationships of the Bad Vermillion Lake greenstone belt. (a) Foliated and folded mafic volcanic rock (basalt). (b) Foliated and folded mafic volcanic rock (basalt).

(c) Felsic volcanic rock (rhyolite). (d) Layered gabbro. (e) Massive gabbro. (f) Polymictic conglomerate, consisting of greenstone, gabbro and gneiss boulders

2.3. Field photographs illustrating the lithological characteristics and field relationships of the Seine Group (Timiskaming-type) sandstone and Ottertail Lake granite. (a) Polymictic conglomerate, consisting of greenstone, pyroclastic, gabbro, and gneiss boulders. (b) Foliated and Folded sandstone (greywacke). (c) Intrusive contact between the BVL greenstone belt and Ottertail Lake granite. (d) Intrusive contact between the BVL greenstone belt and the Ottertail Lake granite. (e) Ottertail Lake granite. (f) Ottertail Lake granite

2.6. Photomicrographs illustrating the petrographic characteristics of the BVL greenstone belt. (a) Mafic volcanic rock (basalt) mainly consisting of plagioclase and chlorite, and minor quartz. (b) Mafic volcanic rock (basalt) mainly consisting of plagioclase, chlorite, and opaque mineral. (c) Altered mafic volcanic rock consisting mainly of calcite and quartz. (d) Felsic volcanic rock (rhyolite) including quartz phenocrysts. (e) Felsic volcanic rock (rhyolite) including quartz phenocrysts.

(f) Gabbro characterized by altered plagioclase, chlorite, and amphibole

2.7. U-Pb Concordia diagrams for the analyzed zircons illustrating the ages of the samples BVL2013-030, BVL2013-031, BVL2013-034 in the BVL greenstone belt, and the Ottertail Lake granite sample BVL2013-058element concentrations in analyzed zircons

2.8. (a) $\mathrm{Zr} / \mathrm{TiO}_{2}$ versus $\mathrm{SiO}_{2}$ (after Winchester and Floyd, 1977) and (b) $\mathrm{FeO}_{\mathrm{T}}$-total alkalis $\left(\mathrm{Na}_{2} \mathrm{O}+\mathrm{K}_{2} \mathrm{O}\right)-\mathrm{MgO}$ diagram (after Irvine and Baragar, 1971) chemical classification diagram for volcanic rocks from the BVL greenstone belt. In the diagram, 'TrAn' denotes Trachyte-Andesite; 'Ab' denotes Alkaline-Basalt; 'Tonga' represents the relative distribution of volcanic products from Tonga trench, a typical intra-oceanic arc setting

2.9. (a-f) Variation diagrams of $\mathrm{Zr}$ versus $\mathrm{TiO}_{2}$ (wt.\%), $\mathrm{Al}_{2} \mathrm{O}_{3}$ (wt.\%), $\mathrm{MgO}$ (wt.\%), $\mathrm{P}_{2} \mathrm{O}_{5}$ (wt.\%), $\mathrm{Fe}_{2} \mathrm{O}_{3}$ (wt.\%), and $\mathrm{CaO}$ (wt.\%), for mafic to felsic volcanic and volcaniclastic rocks in the $\mathrm{BVL}$ greenstone belt 
2.10. (a-f) Variation diagrams of $\mathrm{Zr}$ versus $\mathrm{Nb}$ (ppm), $\mathrm{Ni}(\mathrm{ppm}), \mathrm{La}(\mathrm{ppm}), \mathrm{Sc}(\mathrm{ppm})$, $\mathrm{Cr}$ (ppm), and Y (ppm) for mafic to felsic volcanic and volcaniclastic rocks in the BVL greenstone belt

2.11. N-MORB-normalized REE diagrams for (a) mafic volcanic rocks (mostly basalt), (b) intermediate volcanic rocks, (c) intermediate to felsic volcanic rocks, (d) porphyritic felsic volcanic rocks (rhyolites), (e) felsic volcaniclastic rocks, (f) gabbros, (g) siliciclastic sedimentary rocks, and (h) the Ottertail Lake granite. Normalization values are from Sun and McDonough (1989)

2.12. Chondrite-normalized trace element diagrams for (a) mafic volcanic rocks (mostly basalt), (b) intermediate volcanic rocks, (c) intermediate to felsic volcanic rocks, (d) porphyritic felsic volcanic rocks (rhyolites), (e) felsic volcaniclastic rocks, (f) gabbros, (g) siliciclastic sedimentary rocks, and (h) the Ottertail Lake granite. Normalization values are from Sun and McDonough (1989)

2.13. (a) $\mathrm{Nb}$ versus $\mathrm{Y}$ and (b) $\mathrm{Rb}$ versus $\mathrm{Y}+\mathrm{Nb}$ tectonic discriminant diagrams for the Ottertail Lake granite (after Pearce et al., 1984). VAG: Volcanic Arc Granite; WPG: Within Plate Granite; ORG: Ocean Ridge Granite; syn-COLG: syn-Collision Granite

2.14. (a) ${ }^{147} \mathrm{Sm} /{ }^{144} \mathrm{Nd}$ versus ${ }^{143} \mathrm{Nd} /{ }^{144} \mathrm{Nd}$, (b) ${ }^{206} \mathrm{~Pb} /{ }^{204} \mathrm{~Pb}$ versus ${ }^{207} \mathrm{~Pb} /{ }^{204} \mathrm{~Pb}$, (c) ${ }^{206} \mathrm{~Pb} /{ }^{204} \mathrm{~Pb}$ versus ${ }^{207} \mathrm{~Pb} /{ }^{204} \mathrm{~Pb}$, and (d) ${ }^{87} \mathrm{Rb} /{ }^{86} \mathrm{Sr}$ versus ${ }^{87} \mathrm{Sr} /{ }^{86} \mathrm{Sr}$ plots for the BVL greenstone belt rocks

2.15. (a-f) ${ }^{143} \mathrm{Nd} /{ }^{144} \mathrm{Nd}$ versus $\mathrm{SiO}_{2}$ (wt. \%), $\mathrm{Nb}$ (ppm), Y (ppm), $\mathrm{MgO}$ (wt. \%), Ni (ppm) and La (ppm) plots for the BVL greenstone belt rocks .................................... 80

2.16. (a-f) ${ }^{206} \mathrm{~Pb} /{ }^{204} \mathrm{~Pb}$ versus $\mathrm{SiO}_{2}$ (wt.\%), $\mathrm{TiO}_{2}$ (wt.\%), $\mathrm{K}_{2} \mathrm{O}$ (wt.\%), $\mathrm{MgO}$ (wt.\%), $\mathrm{La}(\mathrm{ppm})$, and $\mathrm{Ni}(\mathrm{ppm})$ plots for the $\mathrm{BVL}$ greenstone belt rocks

2.17. ${ }^{87} \mathrm{Sr} /{ }^{86} \mathrm{Sr}$ versus $\mathrm{SiO}_{2}$ (wt.\%), $\mathrm{TiO}_{2}$ (wt.\%), $\mathrm{La}$ (wt.\%), $\mathrm{MgO}$ (wt.\%), $\mathrm{K}_{2} \mathrm{O}$ (wt.\%), and $\mathrm{Zr}$ (ppm) plots for the BVL greenstone belt rocks 


\section{CHAPTER 1.}

\section{Introduction}

\subsection{Backgrounds on Archean greenstone belts}

Greenstone belts are empirically described as deformed and metamorphosed volcano-sedimentary successions (Anhaeusser, 2014). The greenstone belts are often enveloped by high-alumina tonalite-trondhjemite-granodiorite (TTG) gneiss and latetectonic granites to form the granitoid-greenstone terrane (Condie, 1981; 1994). The accretion and amalgamation of many small granitoid-greenstone terranes gradually shape most Archean cratons (Windley, 1995; Kusky and Vearncombe, 1997; Kusky and Polat, 1998; Percival et al., 2012). Accordingly, greenstone belts provide important information on the geological processes in the early Earth.

Greenstone belts usually crop out as elongate slivers of supracrustal successions in most Archean granite-greenstone terranes (Condie, 2007). Most of the exposed greenstone belts range from 5 to $250 \mathrm{~km}$ in width, 100 to $300 \mathrm{~km}$ in length, and 10-20 $\mathrm{km}$ in thickness (Condie, 1981). The volcano-sedimentary successions of Archean greenstone belts usually include $80 \%$ ultramafic to felsic volcanic and volcaniclastic rocks as well as $20 \%$ chemical and siliciclastic sedimentary rocks (Condie, 1994). In addition, Archean greenstone belts are always related to layered ultramafic-mafic complexes and anorthosite complexes (Anhaeusser, 2014). Metamorphic grades of Archean greenstone belts may increase from prehnite-pumpellyite facies, through greenschist facies, to amphibolite facies (Wilkins, 1997). Due to multiple tectonic deformation and extensive regional metamorphism, nearly all the Archean greenstone belts display various metasomatic alteration effects (Anhaeusser, 2014). Because of the alteration, ultramafic and mafic lithologies are converted to low-grade mineral 
assemblages of serpentine, chlorite, epidote and hornblende (Hunter and Stowe, 1997). Although the dating of greenstone belts show a time spanning from $4300 \mathrm{Ma}$ to 517 Ma (summarized by Furnes et al., 2015), but the most widespread belts were formed in Neoarchean between $2700 \mathrm{Ma}$ and $2600 \mathrm{Ma}$ (Condie, 1981). This time slot also corresponds to the major period of gigantic ultramafic to mafic volcanisms, TTG emplacement, as well as the formation of the earliest volcanogenic massive sulphide (VMS) and mesothermal gold deposits in the early earth history (Windley, 1995; Taylor and McLennan, 1995; Kerrich and Wyman, 1996; Polat and Kerrich, 2001; Van Kranendonk, 2007).

Ophiolite represents fragments of oceanic lithosphere that have been emplaced in orogenic belts due to collision or subduction-accretion events (Dewey and Bird, 1971; Coleman, 1977; Nicolas, 1989). The typical Penrose-type ophiolites include, from bottom to top, the following lithologic units: 1) tectonized peridotites; 2) cumulate peridotites and pyroxenites; 3) layered gabbros; 4) sheeted basaltic dikes; 5) pillow basalts; 6) Deep sea sediments (Autonomous, 1972). The Archean greenstone belts do contain two or more parts of Penrose-type ophiolites (e.g., Kusky 1990, 1991; King and Helmstaedt, 1997; de Wit, 2004), which suggest that plate tectonic processes, might be in different styles, were operative in Archean (Kusky and Polat, 1999). Recent research broadened ophiolites' definition as suites of temporally and spatially associated ultramafic to felsic rocks associated with particular tectonic environments (Dilek and Furnes, 2011). Based on the geochemical signature of basaltic components, the ophiolites can be classified as subduction-related type and subduction-unrelated type (Dilek and Furnes, 2011). The subduction-related ophiolites include suprasubduction-zone and volcanic-arc types; while the subduction-unrelated ophiolites include continental-margin, mid-ocean-ridge and plume types (Dilek and 
Furnes, 2011, 2014; Furnes, 2015). Some Archean greenstone belts showing intraoceanic geochemical signatures can represent Precambrian ophiolites (Furnes et al., 2007; Delik and Polat, 2008; Furnes et al., 2009, 2012), the tectonic classification can also apply to the Archean greenstone belts. In that case, the systematic study of the Archean greenstone belts has indispensable implications for the understanding of geodynamics of the early earth.

Granitic intrusions are well-preserved in Archean greenstone belts on all continents (de Wit, 1998). The earliest stage of granitic intrusions is marked by voluminous sodium-rich TTG suites; whereas the latest stage of intrusions are dominated by potassium-rich granites (de Wit, 1998; Anhaeusser, 2014). The TTG suites originate by partial melting of basaltic source, in combination with fractional crystallization of parental melt (e.g., Benn and Moyen, 2008; Moyen et al., 2007). The potassium-rich granites were derived through interaction between TTG melts and evolved mantle peridotites in an extensional environment after major orogenies (Sylvester, 1994; Evans and Hanson, 1997; Moyen, 2009). The Neoarchean sees a dramatic decrease in the abundance of TTG intrusion, with a progressive replacement of potassic granite (Moyen and Martin, 2012). This transformation may be either attributed to the change of the plate tectonic style (Martin, 1993; Stern, 2008), or caused by the temporary shutdown of plate tectonics at the end of Archean (Condie et al., 2009; O’ Neil et al., 2007).

The Archean geodynamic processes remains controversial despite the recognition of plate tectonic operation during this time slot (Eriksson and Catuneanu, 2004; Turner, 2014; Furnes et al., 2014, 2015). The main divergence lies to the relative importance of plate tectonics versus thermal convection models in the Archean geodynamic processes (Kerrich and Polat, 2006). The plate tectonic paradigms are 
mainly based on field, geochemical and geochronological data from Archean craton worldwide (e.g., Polat et al., 2002; Nutman et al., 2013; Wang, 2013; Backeberg et al., 2014). In contrast, the thermal convection models are generally built upon numerical simulations (Hamilton, 1998; Bédard, 2006; Thebaud and Rey, 2013). Meanwhile, some scientists proposed that both horizontal plate tectonic processes and vertical thermal convection do exist in the Archean (Van Kranendonk et al., 2014; Lin, 2005; Smithies et al., 2007). As a major component of Archean cratons, greenstone belts and associated granitic rocks preserve important geochemical and structural information, which can be utilized to test geodynamic hypothesis of the early earth system.

\subsection{Greenstone belts in the Superior Province}

The Superior Province covers the largest area among the 21 major Archean crusts in the world (Fig. 1.1). In addition, it preserves many linear volcano-plutonic or metasedimentary subprovinces (Card and Ciesielski, 1986). Moreover, it shows the deepest lithospheric keel in North America (Silver and Chan, 1988). All of these characteristics above make Superior Province an ideal platform to study Precambrian geology. Archean greenstone belts in the Superior Province can be generally divided into two types: (1) subduction related bimodal tholeiitic to calc-alkaline basalt to rhyolite association (e.g. Polat et al., 1998; Polat and Kerrich, 1999; Daigneault et al., 2000); (2) plume-derived komatiite-tholeiite association (e.g., Xie et al., 1993; Tomlinson et al., 1999; Dostal and Muller, 2013). Additionally, minor amounts of arcrelated rocks such as boninite, Low-Ti tholeiite, picrite, high-magnesian andesite, adakite, and $\mathrm{Nb}$-enriched basalt can also be found in these greenstone belts (summarized by Kerrich and Polat, 2006; Polat, 2009). Nevertheless, volcanic assemblages with different chemical affinities can coexist together due to plume-arc 
interactions (Wyman and Kerrich, 2009). For example, the coexistence of (1) 2750$2700 \mathrm{Ma}$ bimodal tholeiitic to calc-alkaline associations and (2) 2730-2705 Ma tholeiitic basalts and komatiites reflect plume controlled flat subduction in the AbitibiWawa greenstone belt (Wyman et al., 2002).

Among all the greenstone belts in the Superior Province, the Bad Vermillion Lake (BVL) greenstone belt in the western Wabigoon subprovince is my targeting object. The BVL belt locates in the Rainy Lake area, near the fault boundary between Quetico metasedimentary province and the granitoid-greenstone terrane of western Wabigoon subprovince (Fig. 1.2). Previous structural studies show that the BVL greenstone belt has experienced at least three deformation events $\left(D_{1}-D_{3}\right)$, which have resulted in the prevalent inversion of stratigraphic sequences (Poulsen et al., 1980). The study area has affected by low grade regional metamorphism (Winkler, 1974). Petrographic investigation and geochemical analyses have revealed the composition of mafic to felsic volcanic rocks, mafic dikes, and some felsic intrusions in the BVL greenstone belt (Ashwal, 1983). The latest geochronological studies examined the formation age of major lithologic units (Davis et al., 1989). Based on the subsequent order of volcanic eruption, sedimentation, deformation and granitic intrusions, Davis et al. (1989) pointed out that plate collision play an important role in the formation of the BVL greenstone belt.

Despite many geologists has made advances in understanding the geological evolution in the BVL greenstone belt and associated granitic intrusion (e.g., Ottertail Lake granite), several problems still remain unsolved: (1) geochemical and dating data may not be reliable due to limited precision of contemporaneous experimental facilities; (2) Mineralogical and geochemical composition of siliciclastic rocks from the BVL greenstone belts have not been explored; (3) Effects of metamorphism on 
element mobility within the rock units have not been estimated; (4) Petrogenetic links between different rock units in the BVL greenstone belt remain ambiguous; (5) Specific tectonic settings that favored the generation of the BVL greenstone belt and the Ottertail Lake granite have not been ascertained; (6) Tectonic evolution of the western Wabigoon subprovince and its neighbours is still vague. In order to solve these problems, I have done detailed geochemical and geochronological studies on each rock units from the BVL greenstone belts as well as the Ottertail Lake granite to test possible petrogenetic and geodynamic model for this region.

\subsection{Purpose of Studies}

The principal purposes of conduct this research is to determine the source characteristics and tectonic evolution of the BVL greenstone belt and associated granitic intrusions. This study has profound significance is assessing mantle composition and the style of plate tectonics in Neoarchean. New whole-rock major and trace elements, $\mathrm{Nd}, \mathrm{Pb}$, and $\mathrm{Sr}$ Isotopes, and $\mathrm{U}-\mathrm{Pb}$ zircon age data of the major rock units in the BVL greenstone belt and Ottertail Lake granite have been integrated to explore the following scientific questions:

(1) What were the influences of metamorphic alteration on elemental mobility of the BVL greenstone belt?

(2) When did the BVL greenstone belt and Ottertail Lake granite form, and how did the formation ages constrain on the regional tectonic evolution?

(3) What were the source characteristics of the BVL greenstone belt and the Ottertail Lake granite?

(4) What geodynamic processes shaped the BVL greenstone belt and the Ottertail Lake granite? 
(5) What are the petrogenetic and tectonic implications can the BVL greenstone belt and associated granitic rocks make?

\subsection{Structure of Thesis}

This thesis is composed of three main chapters. Chapter 1 is the introduction for the thesis. Chapter 2 is a manuscript that has been submitted to a peer reviewed journal. Chapter 3 presents a summary of this study. Among all the chapters, chapter 2 is the most important chapter and undoubtedly the core of the master project research.

A version of Chapter 2 has been submitted as a research article in Precambrian Research. This chapter presents field relationships, petrographic observation, high precision geochemical data, $\mathrm{Nd}, \mathrm{Sr}$ and $\mathrm{Pb}$ isotope systematics, as well as $\mathrm{U}-\mathrm{Pb}$ zircon data of the major rock units in the BVL greenstone belt and Ottertail Lake granite. Through detailed field work, the major rock units of the BVL greenstone belt and Ottertail Lake granite have been defined and sampled. Based on petrographic investigation, prevalent metamorphic alteration severely modified primary mineralogy and textures in the BVL greenstone belt; while the Ottertail Lake granite remain less altered. High precision major and trace element geochemistry of 4 samples from the BVL greenstone belt and were analyzed to understand the geochemical signature of these rocks. The $\mathrm{Nd}, \mathrm{Sr}$ and $\mathrm{Pb}$ isotopic studies reveal that the severe alteration has devastated the whole-rock $\mathrm{Rb}-\mathrm{Sr}$ and $\mathrm{Sm}-\mathrm{Nd}$ isotopic systems, but caused insignificant effects on the U-Pb system. In addition, the isotopic data unravel the source characteristics of the BVL greenstone belt and Ottertail Lake granite. U-Pb zircon dating has constrained the formation ages of both BVL greenstone belt and Ottertail Lake granite, thus providing implications on tectonic evolution of west Wabigoon subprovince. 


\subsection{References}

Anhaeusser, C.R., 2014. Archaean greenstone belts and associated granitic rocks-A review. Journal of African Earth Sciences 100, 684-732.

Autonomous, 1972. Penrose filed conference on ophiolites. Geotimes 17, 24-25.

Bédard, J.H., 2006. A catalytic delamination-driven model for coupled genesis of Archean crust and sub-continental lithospheric mantle. Geochimica et Cosmochimica Acta 70, 1188-1214.

Backeberg, N.R., Rowe, C.D., van Hinsberg, V.J., Bellefroid, E.J., 2014. Structural and metamorphic evidence for Mesoarchaean subduction in the Finlayson Lake greenstone belt, Superior Province, Ontario. Precambrian Research 249, 100-114.

Benn, K., Moyen, J.-F., 2008. Geodynamic origin and tectonomagmatic evolution of the Late Archean Abitibi-Opatica terrane, Superior Province: magmatic modification of a plateau-type crust and plume-subduction interaction. In: Condie, K.C., Pease, V. (Eds.), When Did Plate Tectonics Begin on Earth? Geological Society of America, Boulder, pp. 173-198.

Card, K.D., Ciesielski, A., 1986. DNAG\#1: Subdivision of the Superior Province of the Canadian Shield. Geoscience Canada 13, 5-13.

Condie, K.C., 1981. Archaean greenstone belts. In: Windley, B.F. (Ed.), Elsevier scientific publishing company, Amsterdam, Netherlands, pp. 1-44.

Condie, K.C., 1994. Greenstones through time. In: Condie, K.C. (Ed.), Archaean Crustal Evolution. Elsevier, Amsterdam, pp. 85-120.

Condie, K.C., 2007. The distribution of Paleoarchean crust. In: Van Kranendonk, M.J., Smithies, R.H., Bennett, V.C. (Eds.), Earth's Oldest Rocks-Developments in Precambrian Geology 15, Elsevier, Amsterdam, pp. 9-18. 
Coleman, R.G., 1971. Plate tectonic emplacement of upper mantle peridotites along continental edges. Journal of Geophysical Research 76, 1212-1222.

Davis, D.W., Poulsen, K., Kamo, S., 1989. New insights into Archean crustal development from geochronology in the Rainy Lake area, Superior Province, Canada. The Journal of Geology 97(4), 379-398.

Daigneault, R., Mueller, W.U., Chown, E.H., 2002. Oblique Archean subduction: accretion and exhumation of an oceanic arc during dextral transpression, Southern Volcanic Zone, Abitibi Subprovince, Canada. Precambrian Research $115,261-290$.

de Wit, M.J., 1998. On Archean granites, greenstones, cratons and tectonics: does the evidence demand a verdict? Precambrian Research 91, 181-226.

de Wit, M.J., 2004. Archean Greenstone Belts do contain fragments of ophiolites. In: Kusky, T.M. (Ed.), Precambrian Ophiolites and Related Rocks. In: Developments in Precambrian Geology, vol. 13. Elsevier, Amsterdam, pp. 599-613.

Dewey, J.F., Bird, J.M., 1971. The origin and emplacement of the ophiolites suite: Application ophiolites in Newfoundland. Journal of Geophysical Research 76, 3179-3206.

Dilek, Y., Furnes, H., 2011. Ophiolite genesis and global tectonics: geochemical and tectonic fingerprinting of ancient oceanic lithosphere. Geological Society of America Bulletin 123, 387-411.

Dilek, Y., Furnes, H., 2014. Ophiolites and their origins. Elements 10, 93-100.

Dilek, Y., Polat, A., 2008. Suprasubduction zone ophiolites and Archean tectonics. Geology 36 (5), 431-432.

Dostal, J., Mueller, W.U., 2013. Deciphering an Archean mantle plume: Abitibi greenstone belt, Canada. Gondwana Research 23, 493-505. 
Eriksson, P.G., Catuneanu, O. Nelson, D.R., Mueller, W.U., Alterman, W., 2004. Towards a synthesis. In: Eriksson, P.G., Altermann, W., Nelson, D.R., Mueller, W.U., Catuneanu, O., (Eds.). The Precambrian Earth: Tempos and Events. Developments in Precambrian Geology 12, 739-769.

Evans, O.C., Hanson, G.N., 1997. Late-to post-kinematic Archean granitoids of the S.W. Superior Province: derivation through direct mantle melting. In de Wit, M.J., Ashwal, L.D. (Eds.), Greenstone Belts. Oxford University Press, Oxford, pp. 280-295,

Furnes, H., de Wit, M., Staudigel, H., Rosing, M., Muehlenbachs, K., 2007. A vestige of Earth's oldest ophiolite. Science 315, 1704-1707.

Furnes, H., de Wit, M., Dilek, Y., 2014. Four billion years of ophiolite reveal secular trends in oceanic crust formation. Geoscience Frontiers 5, 571-603.

Furnes, H., Dilek, Y., de Wit, M., 2015. Precambrian greenstone sequences represent different ophiolite types. Gondwana Research 27, 649-685.

Furnes, H., Robins, B., de Wit, M.J., 2012.Geochemistry and petrology of lavas in the upper Onverwacht Suite, Barberton Mountain Land, South Africa. South African Journal of Geology 115 (2), 171-210.

Furnes, H., Rosing, M., Dilek, Y., de Wit, M., 2009. Isua supracrustal belt (Greenland) - a vestige of a 3.8 Ga suprasubduction zone ophiolite, and implications for Archean geology. Lithos 113, 115-132.

Goodwin, A.M., 1991. Precambrian Geology-The Dynamic Evolution of the Continental Crust. Academic Press, London, pp. 4-6.

Hamilton, W.B., 1998. Archean tectonics and magmatism. International Geology Review 40, 1-39.

Hunter, D.R., Stowe, C.W., 1997. A historical review of the origin, composition, and 
setting of Archean greenstone belts (pre-1980). In: De Wit, M.J., Ashwal, L.D. (Eds.), Greenstone Belts, vol. 1. Clarendon Press, Oxford, pp. 5-29.

King, J.E., Helmstaedt, H., 1997. The Slave Province, North-West Territories, Canada. In: de Wit, M., Ashwal, L.D. (Eds.), Greenstone Belts. In: Oxford Monographs on Geology and Geophysics, vol. 35, pp. 459-479.

Kerrich, R., Polat, A., 2006. Archean greenstone-tonalite duality: thermochemical mantle convection models or plate tectonics in the early Earth global dynamics? Tectonophysics 415, 141-165.

Kerrich, R., Wyman, D.A., 1996. The trace element systematics of igneous rocks in mineral exploration, an overview. In: D. A. Wyman (Ed.), Trace Element Geochemistry of Volcanic Rocks: Application for Massive Sulphide Exploration. Geological Association-Mineralogical Association of Canada, Short Course Notes 12, 1-50.

Kusky, T.M., 1990. Evidence for Archean ocean opening and closing in the southern Slave Province. Tectonics 9, 1533-1563.

Kusky, T.M., 1991. Structural development of an Archean orogen, western Point Lake, Northwest Territories. Tectonics 10, 820-841.

Kusky, T.M., Vearncombe, J.R., 1997. Structure of Archean greenstone belts. In: Tectonic evolution of greenstone belts. In: de Wit, M., Ashwal, L. (Eds.), Oxford Monographs on Geology and Geophysics, pp. 91-24.

Kusky, T.M., Polat, A., 1999. Archean greenstone belt evolution: implications for continental growth. Tectonophysics 305, 43-73.

Lin, S., 2005. Synchronous vertical and horizontal tectonism in the Neoarchean: Kinematic evidence from a synclinal keel in the northwestern Superior craton, Canada. Precambrian Research 139, 181-194. 
Martin, H., 1988. Archaean and modern granitoids as indicators of changes in geodynamic processes. Revista Brasileira de Geociencias 17 (360), 365.

Moyen, J.-F., Stevens, G., Kisters, A.F.M., Belcher, R.W., 2007. TTG plutons of the Barberton granitoid-greenstone terrain, South Africa. In: Van Kranendonk, M.J., Smithies, R.H., Bennett, V. (Eds.), Earth's Oldest Rocks. Elsevier, pp. 606-668. Moyen, J.-F., 2009. High $\mathrm{Sr} / \mathrm{Y}$ and $\mathrm{La} / \mathrm{Yb}$ ratios: the meaning of the "adakitic signature”. Lithos 112, 556-574.

Moyen, J. F., Martin, H., 2012. Forty years of TTG research. Lithos, 148: 312-336.

Nicolas, A., 1989. Structure of Ophiolites and Dynamics of Oceanic Lithosphere: Dordrecht, the Netherlands, Kluwer Academic Publishers, 367 p.

Nutman, A.P., Bennett, V.C., Friend, C.R.L., Yi, K., Lee, S.R., 2015. Mesoarchaean collision of Kapisilik terrane 3070 Ma juvenile arc rocks and >3600 Ma Isukasia terrane continental crust (Greenland). Precambrian Research 258, 146-160.

O'Neill, C., Lenardic, A., Moresi, L., Torsvik, T.H., Lee, C.A., 2007. Episodic Precambrian subduction. Earth and Planetary Science Letters 262, 552-562.

Percival, J.A., Skulski, T., Sanborn-Barrie, M., Stott, G.M., Leclair, A.D., Corkery, M.T., Boily, M., 2012. Geology and tectonic evolution of the Superior Province, Canada. In: Tectonic Styles in Canada: The Lithoprobe Perspective. In: Percival, J.A., Cook, F.A., Clowes, R.M. (Eds), Geological Association of Canada Special Paper 49, pp. 321-378.

Polat, A., 2009. The geochemistry of Neoarchean (ca. $2700 \mathrm{Ma}$ ) tholeiitic basalts, transitional to alkaline basalts, and gabbros, Wawa subprovince, Canada: Implications for petrogenetic and geodynamic processes. Precambrian Research $168,83-105$

Polat, A., Kerrich, R., 1999. Formation of an Archean tectonic mélange in the 
Schreiber-Hemlo greenstone belt, Superior province, Canada: implications for Archean subduction-accretion process. Tectonics 18, 733-755

Polat, A., Kerrich, R., 2001. Geodynamic processes, continental growth, and mantle evolution recorded in late Archean greenstone belts of the southern Superior Province, Canada. Precambrian Research 112, 5-25.

Polat, A., Kerrich, R., Wyman, D.A., 1998. The late Archean Schreiber-Hemlo and White River-Dayohessarah greenstone belts, Superior Province: collages of Oceanic plateaus, oceanic arcs, and subduction-accretion complexes. Tectonophysics 294, 295-326.

Polat, A., Kerrich, R., Rosing, M., 2002. Boninite-like volcanic rocks in the 3.7-3.8 Ga Isua greenstone belt, West Greenland: geochemical evidence of intra-oceanic subduction processes in the early Earth. Chemical Geology 184, 231-254.

Poulsen, K.H., Borradaile, G.J., Kehlenbeck, M.M., 1980. An inverted Archean succession at Rainy Lake, Ontario. Canadian Journal of Earth Sciences 17, 13581369.

Silver, P.G., Chan, W.W., 1988. Implications for continental structure and evolution from seismic anisotropy. Nature 335, 34-39

Stern, R.J., 2008. Modern-style plate tectonics began in Neoproterozoic Time: an alternative interpretation of earth's tectonic history. In: Condie, K., Pease, V. (Eds.), When did Plate Tectonics Begin? : Geological Society America Special Paper, pp. 265-280.

Smithies, R.H., Van Kranendonk, M.J., Champion, D.C., 2007. The Mesoarchean emergence of modern-style subduction. Gondwana Research 11, 50-68.

Taylor, S.R., McLennan, S.M., 1985. The continental crust: its composition and evolution. Blackwell, Oxford, pp. 1-312. 
Thébaud, N., Rey, P.F., 2013. Archean gravity-driven tectonics on hot and flooded continents: Controls on long-lived mineralized hydrothermal systems away from continental margins. Precambrian Research 229, 93-104.

Tomlinson, K.Y., Hughes, D.J., Thurston, P.C., Hall, R.P., 1999. Plume magmatism and crustal growth at 2.9 to $3.0 \mathrm{Ga}$ in the Steep Rock and Lumby Lake area, Western Superior Province. Lithos 46, 103-136.

Turner, S., Rushmer, T., Reagan, M., Moyen, J.-F., 2014. Heading down early on? Start of subduction on Earth. Geology 42(2), 139-142.

Van Kranendonk, M.J., 2007. Tectonics of early earth. In: Van Kranendonk, M.J., Smithies, R.H., Bennett, V.C. (Eds.), Earth's oldest rocks. Developments in Precambrian Geology 15, 1105-1116.

Wang, J.P., Kusky, T.M., Polat, A., Wang, L., Deng, H., Wang, S., 2013. A late Archean tectonic mélange in the Central Orogenic Belt, North China Craton. Tectonophysics 608, 929-946.

Wilkins, C., 1997. Regional and Contact Metamorphism. In: de Wit, M., Ashwal, L.D., (Eds.), Greenstone Belts. Oxford Monographs on Geology and Geophysics 35, 126-163.

Windley, B.F., 1995. The Evolving Continents. Wiley, pp. 256.

Winkler, H.G.F., 1974. Petrogenesis of metamorphic rocks. Springer-Verlag, New York, p. 334.

Wyman, D., Kerrich, R., 2009. Plume and arc magmatism in the Abitibi subprovinces: Implications for the origin of Archean continental lithospheric mantle. Precambrian Research 168, 4-22.

Wyman, D., Kerrich, R., Polat, A., 2002. Assembly of Archean cratonic mantle lithosphere and crust: plume-arc interaction in the Abitibi-Wawa subduction- 
accretion complex. Precambrian Research 115, 37-62.

Xie, Q., Kerrich, R., Fan, J., 1993. HFSE/REE fractionations recorded in three komatiite-basalt sequences, Archean Abitibi greenstone belt: implications for multiple plume sources and depths. Geochimica et Cosmochimica Acta 57, $4111-4118$ 


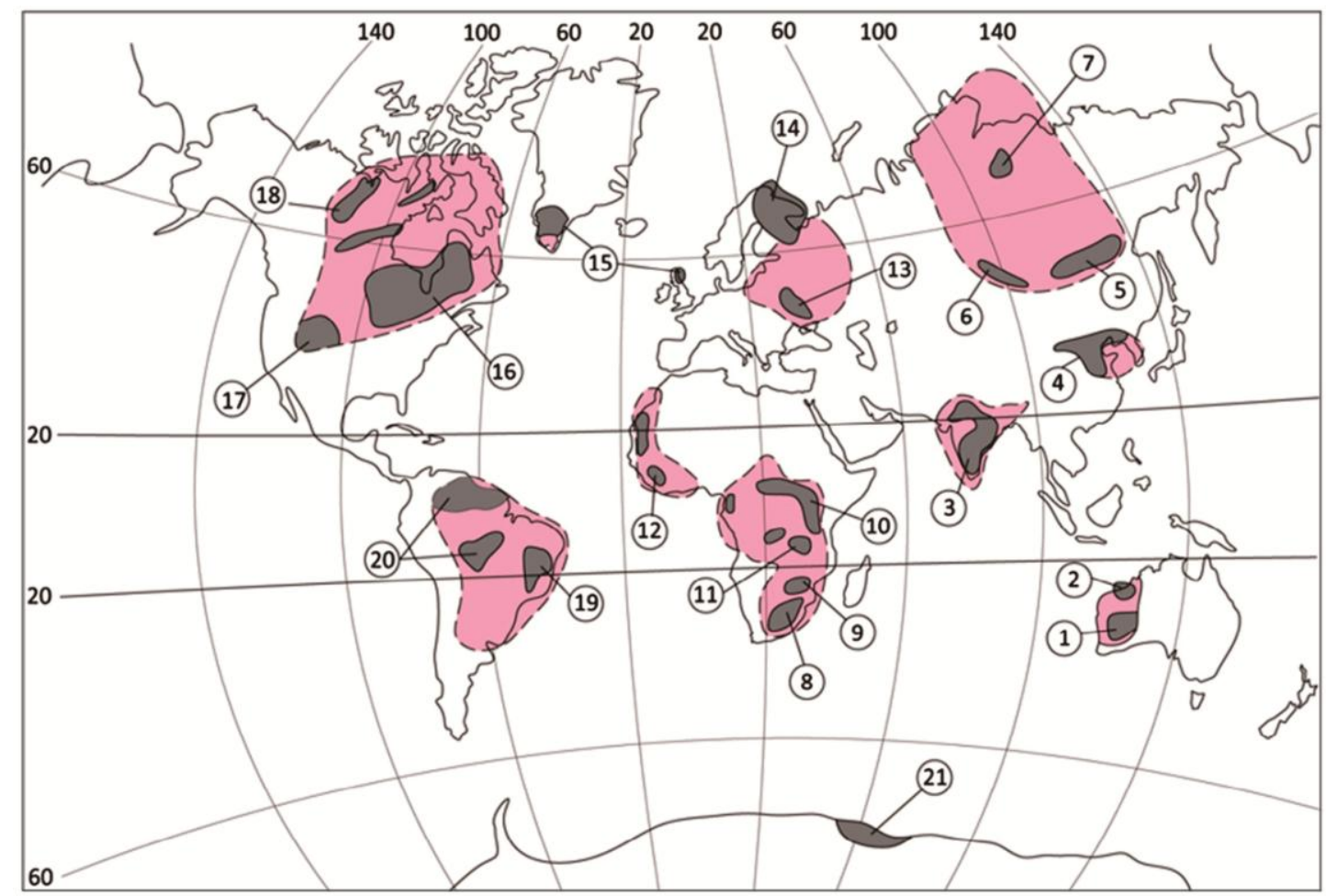

Figure 1.1. Global distribution of Archean crusts (dark grey) and underlain Precambrian basement. The major Archean provinces are listed below: 1=Yilgarn, $2=$ Pilbara, 3=Indian, 4=North China, 5=Aldan-Stanovik, 6=Yenisei, 7=Anabar, 8= Kaapvaal, 9=Zimbabwe, 10=Central African (Tanzanian and northeastern Zaire), 11= Kasai, 12=West African (Liberia, Sierra Leone, Mauritania), 13=Ukranian, 14= Baltic-Svecofennian (Inari-Kola, Karelian), 15=North Atlantic (Greenland, Scotland), 16=Superior, 17=Wyoming, 18=Slave, 19=São Francisco, 20=Amazonian (Guiana, Guaporé), 21=East Antarctica (modified after Condie, 1981; Goodwin, 1991; Anhaeusser, 2014) 


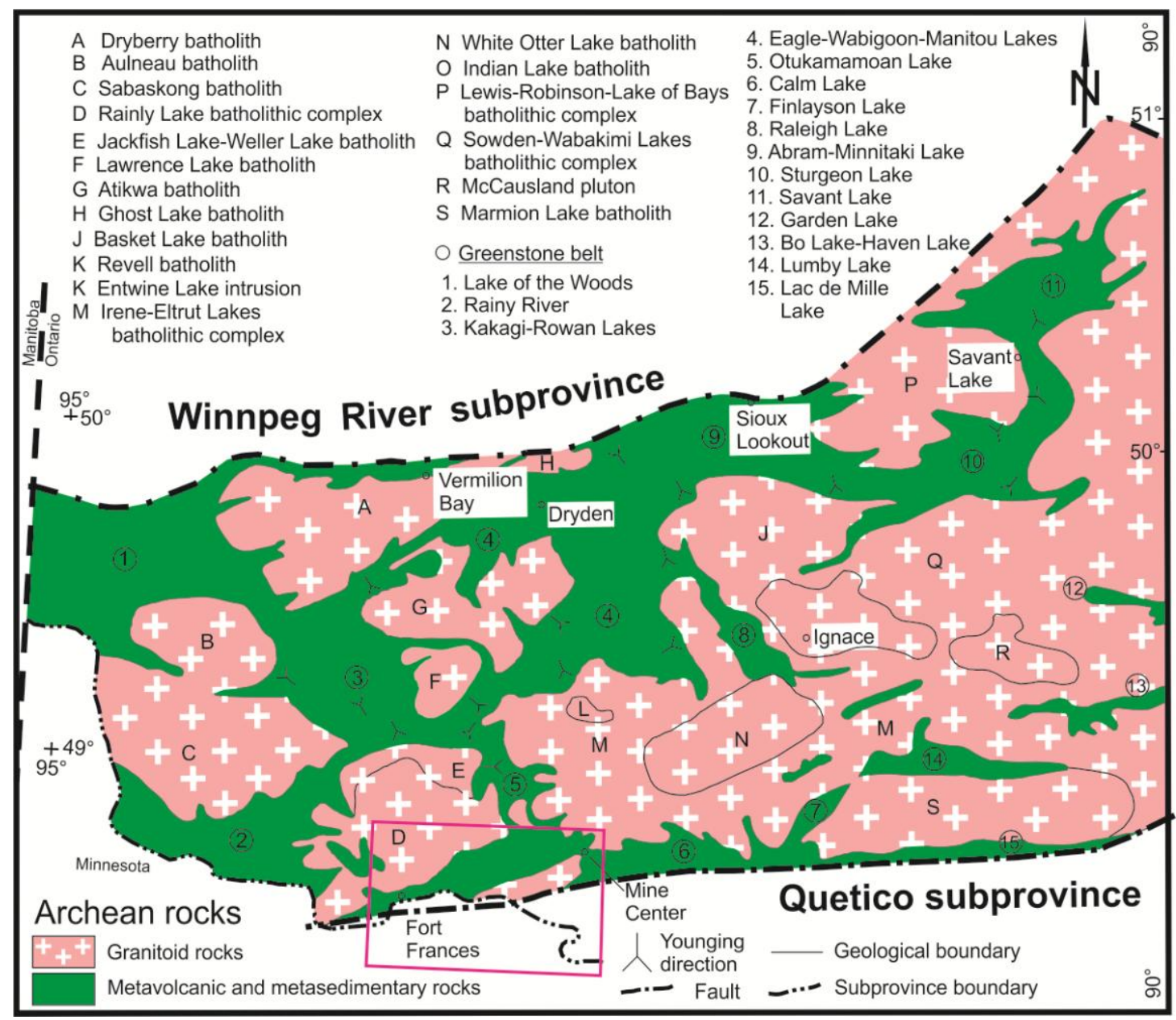

Figure 1.2. Simplified regional geological map of western Wabigoon subprovince, displaying major supracrustal belts (including plutons and greenstone belts) and structure features. 


\section{CHAPTER 2}

\section{Geochemistry, $\mathrm{Nd}, \mathrm{Pb}$ and $\mathrm{Sr}$ Isotope Systematics, and $\mathrm{U}-\mathrm{Pb}$ zircon ages of the Neoarchean Bad Vermilion Lake Greenstone Belt and Spatially Associated Granitic rocks, Western Superior Province, Canada}

\subsection{Introduction}

Archean greenstone belts are characterized by multiply deformed and variably metamorphosed supracrustal sequences (Condie, 1981, 1994; Hunter and Stowe, 1997; Polat et al., 2015). These belts are typically intruded by intermediate to felsic rocks displaying mainly a tonalite-trondhjemite-granodiorite (TTG) affinity; greenstone belts and TTG suites together form the composite granitoid-greenstone terranes in Archean cratons (de Wit, 1997; Sylvester et al., 1997; Anhaeusser, 2014). Lithologically, greenstone belts consists of temporally and spatially related, ultramafic to felsic volcanic rocks, ultramafic to mafic intrusions, and subordinate sedimentary rocks (de Wit, 1998, 2004; Kusky and Polat, 1999; Furnes et al., 2013, 2015). The majority of granitoid-greenstone terranes in the world occur as Mesoarchean to Neoarchean basement (Szilas et al., 2012, 2013; Anhaeusser, 2014; Furnes et al., 2015). The Superior Province is the largest Archean craton in the world and consists of many well-preserved elongated granitoid-greenstone terranes (e.g., Thurston et al., 1991; Corfu and Davis, 1992; Henry et al. 1998, 2000; Tomlinson et al., 2002, 2003; Stott, 1997; Percival et al., 2006a, 2012). Given its well-preserved diverse rock types, the Superior Province provides an excellent opportunity for studying the petrogenetic and geodynamic origins of Archean crust (e.g., Kerrich et al., 1999; Sproule et al., 2002; Whalen et al., 2002; Lodge et al., 2013, 2014, 2015).

Greenstone belts in the Archean Superior Province are dominated by two 
principal volcanic sequences, which are represented by bimodal tholeiitic to calcalkaline basalt to rhyolite association and komatiite-tholeiite association, respectively (Polat and Kerrich, 2002; Sproule et al., 2002; Dostal and Mueller, 2013). The bimodal association is characterized by LREE-enriched patterns and pronounced negative anomalies of $\mathrm{Nb}, \mathrm{Ta}, \mathrm{P}$, and $\mathrm{Ti}$, suggesting a typical intra-oceanic arc magmatism; the komatiite-tholeiite association is featured by high- $\mathrm{Mg}, \mathrm{Cr}$, and $\mathrm{Ni}$ contents, flat rare earth element, as well as complex Th-U-Nb-LREE systematics, indicating a magmatic origin pertinent to mantle plumes (Condie, 1994; Polat et al., 1999; Polat and Kerrich, 2001a; Kerrich and Polat, 2006; Polat, 2009). Greenstone belts in the western Superior Province, contains both types of volcanic associations (Ayer and Davis, 1997; Dostal et al., 2004; Ujike et al., 2007; Tomlinson et al., 1999; Hollings and Kerrich, 2004, 2006).

Tectonic setting of the greenstone belts in the Wabigoon subprovince are still hotly debated (e.g., Hollings and Wyman, 1999; Tomlinson et al., 1999; Wyman et al., 2000; Backeberg et al., 2014). In order to understand the petrogenesis and geodynamic evolution of the Wabigoon subprovince and especially for its western part, we focus on the BVL greenstone belt and its spatially related Ottertail Lake granitic stock on the northern shore of the Rainy Lake (Fig. 2.1b). Given that all rocks in the BVL greenstone belt have been metamorphosed under greenschist facies conditions, the prefix "meta" will be taken as implicit throughout the paper. In this study, we report new major and trace element data for forty-seven samples from the BVL greenstone belt, including volcanic rocks and gabbros, and the spatially associated Seine siliciclastic sedimentary rocks and the Ottertail Lake granitic stock. Seventeen samples from the volcanic rocks and gabbros were analyzed for $\mathrm{Nd}, \mathrm{Pb}$ and Sr isotope systematics. In addition, three rhyolite samples and one granite sample 
were analyzed by zircon $\mathrm{U}-\mathrm{Pb}$ dating to constrain the ages of the greenstone belt and the Ottertail Lake stock. Integrated field and petrographic observations, and geochemical, isotopic and geochronological data are used to constrain the petrogenesis and geodynamic evolution for the BVL greenstone belt, and to assess the effects of post-magmatic processes on element mobility.

\subsection{Regional Geology and field characteristics}

The Superior Province, nucleus of the North American continent, developed by the amalgamation of many distinct protocontinental and oceanic terranes ranging in age from 3.7 to $2.65 \mathrm{Ga}$, during five discrete orogenic events between 2720 and 2680 Ma (Percival et al., 2006a and reference therein). The assembly of these accretionary terranes with the rest of Superior craton was initiated by the collision between the 3.0 Ga North Caribou terrane and the 3.7-2.75 Ga North Hudson Bay terrane at 2720 Ma, and ended by welding of the Minnesota River Valley and Pontiac terranes to the Abitibi-Wawa terrane at $2680 \mathrm{Ma}$, showing an overall orderly north to south progression (Percival et al., 1994, 2006a, b, 2012; Stott, 1997). Seismic reflection and refraction images display common north-dipping structures and variable thickness of 10-15 km among these disparate tectonic fragments (Musacchio et al., 2004; White et al., 2003), supporting the importance of diachronous northward accretionarycollisional process in the formation of the Superior Province. However, plumederived komatiitic and tholeiitic flows are exposed many locations (Xie et al., 1993; Hollings et al., 1999; Polat et al., 1999; Kerrich et al., 1999; Tomlinson et al., 1999; Sproule et al., 2002; Dostal and Mueller, 2013) in the Superior Province, indicating the important role of mantle plume magmatism in the evolution of the Superior Province. A comparison of eastern and central sections of the western Superior 
Province indicates relatively well-preserved east-west trending subprovinces of alternating plutonic, volcanic-plutonic (granitoid-greenstone), high-grade gneissic, and sedimentary rocks. The majority of these linear subprovinces extend along bounding faults for over 1000 km (Fig. 2.1a; Williams, 1990; Stott, 1997; Percival et al., 2006a, b).

The Wabigoon subprovince is a typical granitoid-greenstone composite terrane in the western Superior Province (Fig. 2.1a; Percival et al., 2006a, 2012). It is characterized by ca. $900 \mathrm{~km}$ long, and ca. $150 \mathrm{~km}$ wide east-west trending greenstone belts and platformal carbonate sequences that are intruded by granitoid batholiths, gabbroic sills and stocks of various compositions (Blackburn et al., 1991; Thurston et al., 1991; Stott, 1997; Kusky and Hudleston, 1999). The lithologies of the greenstone belts in the Wabigoon subprovince are dominated by mafic to felsic volcanic rocks and lesser amounts of komatiites and sedimentary rocks, ranging in ages from ca. 3.0 to $2.7 \mathrm{Ga}$ (Blackburn et al., 1991). On the basis of different lithological, structural, and tectonic evolutionary characteristics, the subprovince is divided into three distinct terranes: (1) the eastern Wabigoon terrane, which is composed predominantly of Mesoarchean to Neoarchean (ca. 3056-2720 Ma) supracrustal successions (Stott and Davis, 1999) intruded by ca. 2770-2680 Ma syn- to post-tectonic plutons, in conjunction with Neoarchean (ca. 2740-2720 Ma) mafic to felsic volcanic rocks (Davis, 1999; Kwok et al., 2000); (2) the central Wabigoon terrane, which is characterized by a number of Mesoarchean greenstone belt remnants intruded by several generations of TTG batholiths (Blackburn et al., 1991), such as the ca. 3075 Ma tonalite at Caribou Lake near its northern margin (Davis et al., 1988) and a ca. 3003 Ma tonalite in the Lumby Lake area, the southern part of the region (Davis and Jackson, 1988); and (3) the western Wabigoon terrane, which is mostly dominated by 
large tonalitic to granodioritic batholiths (ca. 2735-2720 Ma; Davis and Edwards, 1982, 1986), surrounded by numerous Neoarchean (ca. 2775-2685 Ma) greenstone belts (Blackburn et al., 1991). The western Wabigoon terrane is also distinct from the other two regions in that it shows juvenile Nd isotopic compositions (Ayer and Dostal, 2000; Ujike et al., 2007), and the absence of inherited zircons older than $2710 \mathrm{Ma}$ (Tomlinson et al., 2003). It is noted that the exact location and nature of the boundaries among the three regions remain ambiguous, and correlations of greenstone belts in different regions are not well-defined.

\subsubsection{The Bad Vermillion Lake (BVL) greenstone belt}

The BVL greenstone belt is bounded to the north by the dextral Quetico fault and the Rainy Lake batholithic complex; while its southern boundary is marked by the dextral Seine River fault, which separates the greenstone belt from the Quetico sedimentary subprovince (Fig. 1b; Wood, 1980; Ashwal et al., 1983; Davis et al., 1989). The Quetico and Seine River faults shape the belt into a triangular wedge block, sharing lithological and structural characteristics of both the Wabigoon and Quetico subprovince along the boundaries (Wood, 1980; Davis et al., 1989). The BVL greenstone belt can be lithogically subdivided into four assemblages: (1) the Keewatin mafic to felsic volcanic rocks (mainly rhyolite and basalt; Fig. 2.2d); (2) the Seine Group pyroclastic rocks (e.g., lapilli tuff and volcanic breccia; Fig. 2.2a), sandstones and conglomerates (Fig. 2.2b); (3) Keewatin gabbros (Fig. 2.2c); and (4) the Coutchiching wackes with minor amounts of mica schist and turbidite (Hart and Davis, 1969; Blackburn et al., 1991). In addition, there are small volumes of felsic sub-volcanic rocks in the belt. Geological mapping indicates that these rock units were inverted and later compressed into an asymmetric synformal anticline (Davis et 
al., 1989; Poulsen et al., 1980; Fig. 2.1b). The core of the fold is occupied by the Neoarchean BVL anorthosite complex, which is characterized by calcic-anorthosite $\left(\mathrm{An}_{80-95}\right)$ with equant plagioclase megacrysts, and two dissimilar gabbroic bodies on its southeastern and northwestern sides. These gabbros include: (1) abundant Fe-Ti oxides, apatite bearing gabbros on the northwestern side (Harris, 1974; Wood et al., 1980); and (2) homogenous and massive gabbros on the southeastern side (Ontario Dept. Mines, 1961). The northeastern and southwestern limbs of the fold are dominated by felsic and mafic volcanic rocks, respectively (Ashwal et al., 1983).

The BVL greenstone belt underwent three phases of deformation (Poulsen et al., 1980). The lower portions of the BVL greenstone belt were structurally overturned and predate the development of dominant $\left(\mathrm{F}_{2}\right)$ folds, resulting in that the older Keewatin volcanic rocks superimpose on the younger Coutchiching sediments (Poulsen et al., 1980). All sedimentary and volcanic successions in the Rainy Lake area were subjected to low to medium grade regional metamorphism in the Neoarchean (Winkler, 1974), the intensity of which increases from the southernmost biotite zone to the central staurolite-cordierite zone, and finally reaches the sillimanite-muscovite zone in the north (Poulsen et al., 1980). Anorthosites and associated gabbros have been extensively metamorphosed under upper greenschist facies conditions (Ashwal et al., 1983).

Rubidium-Sr and Sm-Nd dating of the anorthosites provided errorchron ages of 2690 $\pm 100 \mathrm{Ma}$ and 2740 $\pm 70 \mathrm{Ma}$, respectively (Ashwal et al., 1983). The Rb-Sr isotope data from the Keewatin volcanic rocks yielded an errorchron age of $2770 \mathrm{Ma}$, while the errorchron age for the Coutchiching sedimentary rocks is around $2690 \mathrm{Ma}$, coinciding with an early stage of metamorphism during the Algoman orogeny (Hart and Davis, 1969). Errorchron ages of the Keewatin volcanic rocks and the 
Coutchiching sedimentary rocks are consistent with the zircon intercept age of 2750 Ma (Hart and Davis, 1969). The rhyolite from the northern Keewatin felsic volcanic sequence yielded a crystallization age of about 2728 Ma (Davis et al., 1989; Fig. 2.1b). Another quartz-phyric volcanic rock from the Keewatin sequence several kilometers to the east of the BVL yielded a similar U-Pb zircon age (2727.0 $\pm 1.2 \mathrm{Ma}$; Davis et al., 1989). The detrital zircons from the Coutchiching sedimentary rocks display ${ }^{207} \mathrm{~Pb} /{ }^{206} \mathrm{~Pb}$ ages ranging from $3059 \pm 3 \mathrm{Ma}$ to $2704 \pm 3 \mathrm{Ma}$, while a trondhjemite intrusion in the Seine Group defines a maximum depositional age of $2696 \mathrm{Ma}$ (Davis et al., 1989).

\subsubsection{Ottertail Lake granitic stock}

The granitoid complexes in the Wabigoon subprovince can be divided into three major types: (1) Neoarchean (e.g., 2732-2708 Ma in the western Wabigoon terrane) batholiths which are compositionally varying from TTGs through granite to quartz monzonite; (2) Mesoarchean Basement Complex (e.g., ca. 3075 \pm 3 Ma tonalitic gneisses; Davis, et al., 1988) mainly from the central Wabigoon terrane; and (3) Neoarchean (2709-2685 Ma) post-tectonic monzonitic to granitic stocks, which chiefly scatter in the west Wabigoon terrane and intrude the supracrustal belts and subjacent internal batholiths (Blackburn et al., 1991). According to Ashwal et al. (1983), the elongated and altered felsic intrusions in the BVL region, which also reveals compositional affinities with local felsic volcanic rocks, were produced during the Laurentian plutonism (ca. 2728-2725 Ma; Davis et al., 1989). However, the unaltered, potassic, and juvenile Ottertail Lake granitic stock (Fig. 2.1b) that intrudes nearly all the lithologic units of the BVL greenstone belts (Fig. 2.2e) was thereby interpreted as a late tectonic Algoman granitoid intrusion by Poulsen et al. (1980). 
The Laurentian intrusion provides an $\mathrm{Rb}-\mathrm{Sr}$ errorchron age of $2520 \pm 21 \mathrm{Ma}$, which is significantly younger than the $\mathrm{U}-\mathrm{Pb}$ age $(2750 \mathrm{Ma})$ of the Laurentian inherited zircons (Hart and Davis, 1969). Comparatively, the crystallization age of the undeformed Ottertail Lake Stock was interpreted to be 2686+1/-2 Ma (Davis et al. , 1989). It is speculated that the plutons with voluminous tonalitic compositions such as the Laurentian granitoid originated from partial melting of overthickened amphibolite-dominated lower crustal rocks and assimilation of older tonalite gneisses (Whalen et al., 2004). In contrast, the younger Algoman granitic rocks with monzonitic compositions (Fig. 2f), which are analogous to potassium-rich Granodiorite-Granite-Monzogranite (GGMs), were interpreted to have been produced by melting of metasomatized mantle sources (Sutcliffe et al., 1993; Shirey and Hanson, 1986) and emplaced at the terminal stage of cratonization (Anhaeusser and Robb, 1981).

\subsection{Petrography}

Based on field observations, rocks in the BVL greenstone belt are grouped as mafic (basalt), intermediate (andesite), felsic (rhyolite) volcanic rocks, gabbros, intermediate to felsic volcaniclastic, and siliclastic sedimentary rocks (Figs. 2.2 and 2.3). The volcaniclastic rocks, including tuff, lithic tuff, and quartz-feldspar breccia, are mainly of intermediate to felsic in composition. The intrusive rocks are predominantly gabbros. Primary mineralogy and textures of most igneous rocks have been mostly obliterated by metamorphism and deformation (Figs. 2.4 and 2.5). However, the effects metamorphic alteration and post-tectonic deformation in the spatially associated Ottertail Lake granite are much lower than those in the greenstone belt (Figs. 2.2-2.5). 
Mafic volcanic rocks usually contain subhedral to anhedral grains and display well-developed foliation. They are composed mainly of chlorite (30-40\%), plagioclase $(30-40 \%)$, epidote $(10-20 \%)$, quartz $(5-10 \%)$, calcite $(5-10 \%)$, and opaque minerals $(<5 \%)$ (Fig. $2.4 \mathrm{a}-\mathrm{c})$.

Intermediate volcanic rocks are composed chiefly of fine-grained subhedral to anhedral plagioclase (40-50\%), epidote (10-15\%), chlorite (15-20\%), quartz (10-15\%), calcite (5-10\%), and opaque minerals (5-10\%). Plagioclase is replaced by calcite and epidote.

The majority of felsic volcanic rock outcrops display a porphyritic texture. Phenocrysts $(0.5-5 \mathrm{~mm})$ are predominantly blue quartz and alkaline feldspar, whereas matrix $(0.02-0.1 \mathrm{~mm})$ chiefly consists of microlite, quartz and some mica (Figs. $2.4 \mathrm{~d}$, e). The alkaline feldspars usually display strong albitization and sericitization. The quartz grains are elongated often show irregular boundaries and undulatory extinction.

Pyroclastic rocks in the BVL greenstone belt are composed mainly of tuffs, lithic tuffs, lapilli tuffs and lapilli stones. Some of these rocks also occur within the Seine Group. Our samples are mainly from tuffs and lithic tuffs. These pyroclastic rocks consist of subhedral to anhedral feldspar (30-40\%), quartz (40-50\%), chlorite (10$20 \%)$, calcite $(0-5 \%)$ and opaque minerals $(0-5 \%)$. Feldspars in high-strain areas reveal plastic deformation and recrystallization. All major minerals display weak alignment and, are often transected by quartz veins. Alteration in the vesicular tuff is characterized by silicification, albitization and sericitization.

Gabbros are composed of large grains (up to $2 \mathrm{~cm}$ ) of plagioclase (30-40\%), chlorite (20-30\%), amphibole (5-10\%), epidote (10-15\%), calcite (5-10\%), quartz (510\%), and opaque minerals (0-5\%) (Fig. 4f). Most plagioclase grains have been altered to epidote, calcite and quartz. 
The siliciclastic rocks from the Seine sedimentary rocks are composed of quartz, feldspar, mica, chlorite, calcite, sulphide and rock fragments (Fig. 2.5a, b). Grains are mainly angular and set in fine-grained matrix (Fig. 2.5a, b).

The Ottertail Lake granite consists of biotite (10-20\%), plagioclase (10-20\%), potassium feldspar (30-40\%), quartz $(30-40 \%)$, and accessory minerals $(<5 \%)$ such as amphiboles, muscovite, calcite and Fe-opaque phases (Fig. 2.5c, d). It is usually characterized by subhedral equigranular texture with a grain size between 1 and $5 \mathrm{~mm}$. Most grains are undeformed except for quartz, which often exhibits strained boundaries and undulatory extinction. Plagioclase grains are locally altered to epidote and amphibole (Fig. 2.5c, d).

\subsection{Sampling and analytical methods}

\subsubsection{Sampling}

Samples were collected from mafic, through intermediate, to felsic volcanic rocks, intermediate to felsic volcaniclastic rocks and gabbros from the Keewatin Group, sedimentary rocks from the Seine Group, and the Ottertail Lake granite. GPS coordinates for sample locations are given in Tables 2.1 and 2.2. Sampling was designed to include outcrops with different degrees of alteration minerals proportions and overall deformation to constrain the effects of post-magmatic alteration on element mobility. The weight of the sample ranges from 2 to $4 \mathrm{~kg}$.

\subsubsection{U-Pb zircon geochronology}

Zircon U-Pb dating was conducted on three rhyolite (BVL2013-030, BVL2013031, and BVL2013-034) and one granite (BVL2013-058). Zircon grains were separated at the laboratory of Hebei Institute of Regional Geological Survey and 
Mining in Langfang, China, using conventional magnetic separation and heavy liquid techniques. Separated zircons were handpicked using a binocular microscope. Selected zircons were then adhered to a circular resin target in a line, which was prepared for reflected light, transmitted light, and cathodoluminescence (CL) imaging. Clear, stubby and idiomorphic zircons from the resin target were chosen for $\mathrm{U}-\mathrm{Pb}$ dating on a Laser Ablation Inductively Coupled Plasma Mass Spectrometer (LA-ICPMS), equipped with $193 \mathrm{~nm}$ ArF excimer laser, at the State Key Laboratory of Geological Processes and Mineral Resources, China University of Geosciences, Wuhan.

Detailed operating conditions for the laser ablation system and the ICP-MS instrument data reduction are the same as described by Liu et al. (2008a, b; 2010a, b).

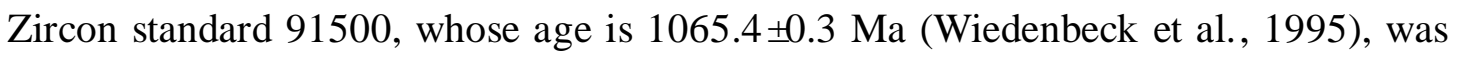
analyzed twice for every five analyses, serving as an external standard for the derived U-Th-Pb data. Concordia diagrams and weighted mean calculations were made by using Isoplot/Ex_ver3 (Ludwig, 2003). Errors on age-plots are 2б. A circular spot with a diameter of $32 \mu \mathrm{m}$ was employed in the U-Pb dating.

\subsubsection{Major and trace element analyses}

Samples were powered and analyzed for whole-rock major and some trace elements (Ba, Sr, Y, Sc, Zr, Be, V) in Activation Laboratories Ltd. (ATCLABS) in Ancaster, Ontario, using a Thermo Jarrell-Ash ENVIRO II ICP. For the preparation of the ICP analyses, molten samples were instantly fused and digested with a solution of 5\% nitric acid containing an internal standard, mixed continuously until completely dissolved (ca. 30 minutes). Loss on ignition (LOI) was determined by measuring the weight loss as resulting from the escape of all volatile (e.g., $\mathrm{H}_{2} \mathrm{O}, \mathrm{CO}_{2}$ ), by strong 
heating of the sample powders to $1100^{\circ} \mathrm{C}$ over three hours. Calibration was made by using seven prepared USGS and CANMET certified reference materials. One of the seven standards was used during the analysis for every group of ten samples. Totals of major elements are $100 \pm 1$ wt.\%, and most of these major elements possess high analytical precision of $1-3 \%$. The analytical precision for the trace elements in the ICP analyses are better than $10 \%$.

Concentrations of high-field strength elements (HFSE), large-ion lithophile elements (LILE), and transition metals (e.g., $\mathrm{Ni}, \mathrm{Co}, \mathrm{Cr}, \mathrm{Cu}$, and $\mathrm{Zn}$ ) in the samples were determined by a high-sensitivity Thermal Elemental X7 Inductively Coupled Plasma Mass Spectrometer (ICP-MS) in the Great Lakes Institute for Environmental Research at the University of Windsor, Canada, adhering to the protocols of Jenner et al. (1990). Approximately 100-120 mg of the sample powders was dissolved in Teflon bombs for $\mathrm{HF}+\mathrm{HNO}_{3}$ acid digestion. Samples were dissolved on a hotplate at temperature between 100 and $120{ }^{\circ} \mathrm{C}$ under clean lab conditions. Hawaiian and Icelandic basalt standard (BHVO-1 and BIR-1) were analyzed as reference materials. In this study, the analytical accuracies are estimated as follows: 1-15\% for REE, Hf, Th, V, Rb, Sr, Cs, Co, Cr and U; 15-30\% for $\mathrm{Nb}, \mathrm{Ta}, \mathrm{Zr}$ and $\mathrm{Y} ;>30 \%$ for $\mathrm{Ba}, \mathrm{Pb}$ and some transitional metals (Supplementary Data Table 1).

Major elements were recalculated to $100 \mathrm{wt} \%$ volatile-free phase for intersample comparisons. Mg-number (\%) were calculated as the molecular ratio of $\mathrm{Mg} /\left(\mathrm{Mg}+\mathrm{Fe}^{2+}\right)$, where $\mathrm{Fe}^{2+}$ is assumed to be $90 \%$ of total $\mathrm{Fe}$. Chondrite and NMORB reservoir compositions used for normalized trace element diagrams are from Sun and McDonough (1989). Europium (Eu/Eu*), Ce (Ce/Ce*), $\mathrm{Nb}(\mathrm{Nb} / \mathrm{Nb} *), \mathrm{Ti}$ $\left(\mathrm{Ti} / \mathrm{Ti} i^{*}\right)$, and $\mathrm{Zr}(\mathrm{Zr} / \mathrm{Zr} *)$ anomalies were calculated relative to their neighboring immobile elements, complying with the principles from Taylor and McLennan 
(1985). Initial epsilon-Nd $(\varepsilon N d)$ values were calculated from the present-day parameters of the Chondrite Uniform Reservoir (CHUR), assuming ${ }^{147} \mathrm{Sm} /{ }^{144} \mathrm{Nd}=0.1967$ and ${ }^{143} \mathrm{Nd} /{ }^{144} \mathrm{Nd}=0.512638$. $\varepsilon \mathrm{Nd}$ values were calculated using zircon U-Pb ages (ca. $2720 \mathrm{Ma}$ ) yielded by felsic volcanic rocks in the BVL greenstone belt.

\subsubsection{Sm-Nd, $U-T h-P b$ and $S r$ isotope analyses}

Based on rock types and chondrite-normalized REE patterns, 17 samples have been selected for $\mathrm{Nd}, \mathrm{Pb}$ and $\mathrm{Sr}$ isotope analyses at the Geological Institute, University of Copenhagen, Denmark. The powdered samples were dissolved by standard procedures u sing concentrated $\mathrm{HNO}_{3}, \mathrm{HCl}$ and $\mathrm{HF}$ within Savillex ${ }^{\mathrm{TM}}$ beakers on a hotplate at $130^{\circ} \mathrm{C}$ for 3 days (see Frei and Polat, 2013). $\mathrm{A}^{150} \mathrm{Nd} /{ }^{147} \mathrm{Sm}$ spike was added beforehand. The isotopic ratios of $\mathrm{Sm}, \mathrm{Nd}, \mathrm{Pb}$ and $\mathrm{Sr}$, and of $\mathrm{Sm}$ and $\mathrm{Nd}$ isotopic dilution concentrations were determined from separately dissolved powder aliquots using a VG Sector 54 IT Thermal Ionization Mass Spectrometer (TIMS) at IGN.

Samples were separated over chromatographic columns charged with $12 \mathrm{ml}$ AG50W-X 8 (100-200 mesh) cation resin, where Sr and REE fractions were collected. REE fractions were further separated over smaller chromatographic columns containing Eichrom's ${ }^{\mathrm{TM}}$ LN resin SPS (Part\#LN-B25-S). Strontium cuts were purified applying a standardized $3 \mathrm{M} \mathrm{HNO}_{3}-\mathrm{H}_{2} \mathrm{O}$ elution recipe on self-made disposable miniextraction columns, which consisted of $1 \mathrm{ml}$ pipette tips in which we fitted a frit filter to retain $0.2 \mathrm{ml}$ intensively pre-cleaned mesh $50-100 \mathrm{SrSpec}^{\mathrm{TM}}$ (Eichrome Inc.) resin. The elution recipe essentially followed that of Horwitz et al. (1992), scaled to our needs. Strontium was eluted/stripped by pure deionized water and then the eluted 
fraction was dried on a hotplate.

Samarium isotopes were measured in a static multi-collection mode, whereas $\mathrm{Nd}$ isotopes were collected in a multi-dynamic routine, both on a triple Ta-Re-Ta filament setting. The measured $\mathrm{Nd}$ isotope ratios were normalized to ${ }^{146} \mathrm{Nd} /{ }^{144} \mathrm{Nd}=0.7219$. The mean value of ${ }^{143} \mathrm{Nd} /{ }^{144} \mathrm{Nd}$ ratios for our JNdi standard runs during the period in which the samples were analyzed amounted to $0.512105 \pm 5(2 \sigma ; n=8)$. Precision for ${ }^{147} \mathrm{Sm} /{ }^{144} \mathrm{Nd}$ ratios is better than $2 \%(2 \sigma)$. Chemical separation of $\mathrm{Pb}$ from the wholerock samples was performed over conventional glass stem and subsequently miniature glass stem anion exchange columns containing, respectively, $1 \mathrm{ml}$ and $200 \mu \mathrm{l}$ of $100-$ 200 mesh Bio-Rad AG 1×8 resin. Lead was analyzed in a static multi-collection-mode where fractionation was controlled by repeated analysis of the NBS 981 standard (using values of Todt et al.1993). The average fractionation amounted to $0.105 \pm 0.008 \%$ $(2 \sigma, n=5)$ per atomic mass unit. Total procedural blanks remained below $<200 \mathrm{pg} \mathrm{Pb}$ which compared to $>100 \mathrm{ng} \mathrm{Pb}$ loads, insignificantly affected the measured $\mathrm{Pb}$ isotopic ratios of the samples. ${ }^{87} \mathrm{Rb} /{ }^{86} \mathrm{Sr}$ ratios were calculated using ICP-MS Rb and Sr data.

\subsection{Results}

\subsubsection{Zircon geochronology}

\subsubsection{Rhyolite samples (BVL2013-030, BVL2013-031, and BVL2013-034)}

Most zircon grains in these three samples show subhedral to anhedral crystal shapes, irregular boundary as well as sporadic occurrence of fractures and fluid or mineral inclusions (Fig. 2.6 a-c). The majority of the grains are characterized by salient magmatic oscillatory zoning with high luminescence in the CL images (Fig. 2.6 a-c); several grains display no zoning (Fig. 2.6b). 
Sample BVL2013-030 contains abundant stubby zircon grains $(100-150 \mu \mathrm{m})$ with subrounded to prismatic edges. They are characterized dominantly by fine oscillatory zoning (Fig. 2.6a). A total of 33 spots on different zircon grains have been analyzed. Thorium and $\mathrm{U}$ contents are 12-86 ppm and 28-102 ppm, respectively, with high $\mathrm{Th} / \mathrm{U}$ ratio of $0.40-0.84$ and high $\mathrm{REE}$ contents (593-2245 ppm) (Table 3; Supplementary Data Table 2). A cluster of 31 analyses from oscillatory grain cores are concordant and yield a ${ }^{207} \mathrm{~Pb} /{ }^{206} \mathrm{~Pb}$ mean age of $2722 \pm 11 \mathrm{Ma}$ (Fig. 2.7a). The range of the ${ }^{207} \mathrm{~Pb} /{ }^{206} \mathrm{~Pb}$ ages span from $2808 \mathrm{Ma}$ to $2576 \mathrm{Ma}$ (Table 2.3 ).

Sample BVL2013-031 yielded small and subrounded grains $(50-150 \mu \mathrm{m})$ with irregular rims. The small zircons are mostly heterogeneous; whereas the larger grains display complex interiors but with generally undisturbed oscillatory zoning (Fig. 2.6b). A total of 19 spots on different zircon grains have been analyzed. The concentrations of Th and $\mathrm{U}$ are 39-1836 ppm and 65-1473 ppm, respectively, yielding elevated Th/U ratios (0.33-1.25) (Table 2.3). Rare earth element contents (1074-16155 ppm) are moderately variable (Supplementary Data Table 2). A cluster of 15 analyses from oscillatory grain zones are concordant and have given a ${ }^{207} \mathrm{~Pb} /{ }^{206} \mathrm{~Pb}$ mean age of $2698 \pm 13 \mathrm{Ma}$ (Fig. 2.7b). Most of the ${ }^{207} \mathrm{~Pb} /{ }^{206} \mathrm{~Pb}$ zircon ages vary from $2733 \mathrm{Ma}$ to $2562 \mathrm{Ma}$, with four exceptionally low ages bracketed between $2604 \mathrm{Ma}$ and $377 \mathrm{Ma}$ (Table 2.3).

Sample BVL2013-034 is dominated by small subhedral zircon grains (50-100 $\mu \mathrm{m})$ with subrounded to prismatic edges. Cathodoluminescence imaging reveals distinct cores with wavy, diffusive, and disrupted oscillatory zoning at outer margins of the grains (Fig. 2.6c). Only 7 spots on well-shaped magmatic zircon grains have been analyzed. These grains display large variation in Th $(245-1560 \mathrm{ppm})$ and U (432-1189 $\mathrm{ppm})$ contents, resulting in high $\mathrm{Th} / \mathrm{U}$ ratios $(0.29-1.32$; Table 2.3). The 
zircon grains are strongly enriched in REE (2836-15578 ppm) (Supplementary Data Table 2). The 7 analyses are basically concordant, and give a ${ }^{207} \mathrm{~Pb} /{ }^{206} \mathrm{~Pb}$ mean age of $2724 \pm 23 \mathrm{Ma}$ (Fig. 2.7c). The ${ }^{207} \mathrm{~Pb} /{ }^{206} \mathrm{~Pb}$ zircon ages range from $2744 \mathrm{Ma}$ to $2692 \mathrm{Ma}$ (Table 2.3).

\subsubsection{Ottertail Lake granite sample (BVL2013-058)}

Sample BVL2013-058 yielded many elongated and prismatic zircons ranging in size from 100 to $200 \mu \mathrm{m}$. Cathodoluminescence images exhibit continuous clear oscillatory zoning developed from the internal core to the edge (Fig. 2.6d). A total of 20 spots on different grains have been analyzed. These grains have variable Th (167$557 \mathrm{ppm})$ and $\mathrm{U}$ contents (178-702 ppm) (Table 2.3). The ratios Th/U vary from 0.69 to 1.13. They have high REE concentrations (1059 -3212 ppm) (Supplementary Data Table 2). Nineteen out of the 20 analyses from the oscillatory cores are concordant, and provided a ${ }^{207} \mathrm{~Pb} /{ }^{206} \mathrm{~Pb}$ mean age of $2664 \pm 15 \mathrm{Ma}$ (Fig. 2.7d). One outlier grain yielded $\mathrm{a}{ }^{207} \mathrm{~Pb} /{ }^{206} \mathrm{~Pb}$ age $(2868 \mathrm{Ma})$ and larger standard age deviation $(1 \sigma=40.805$ Ma). The overall ${ }^{207} \mathrm{~Pb} /{ }^{206} \mathrm{~Pb}$ ages of the zircons are within the bracket of $2868 \mathrm{Ma}$ and $2633 \mathrm{Ma}$ (Table 2.3).

\subsubsection{Major and trace elements}

\subsubsection{Mafic volcanic rocks}

The mafic volcanic rocks are basaltic in composition $\left(\mathrm{MgO}=3-10\right.$ wt. $\%, \mathrm{SiO}_{2}=$ 48.6-54.5 wt. $\%, \quad \mathrm{Fe}_{2} \mathrm{O}_{3}=10.7-19.8$ wt. $\%$ ), and characterized by variable concentrations of $\mathrm{TiO}_{2}$ (0.56-3.70 wt.\%), $\mathrm{CaO}$ (5.3-11.8 wt.\%), $\mathrm{P}_{2} \mathrm{O}_{5}(0.01-0.70$ wt.\%), $\mathrm{Al}_{2} \mathrm{O}_{3}$ (12.0-16.7 wt.\%), $\mathrm{Zr}(60-210) \mathrm{Sc}$ (24-44 ppm), Ni (73-277 ppm), and $\mathrm{Cr}$ (9-277 ppm) (Figs. 2.8-2.10; Table 2.1). Mg-numbers vary between 30 and 58. The ratios of 
$\mathrm{Al}_{2} \mathrm{O}_{3} / \mathrm{TiO}_{2}$ (3-28) and $\mathrm{Ti} / \mathrm{Zr}(46-167)$ are subchondritic to superchondritic whereas the $\mathrm{Zr} / \mathrm{Y}(3.9-10.3)$ ratios are superchondritic (Table 2.1).

The BVL greenstone mafic volcanic rocks plot in the field of subalkaline rocks on the $\mathrm{Zr} / \mathrm{Ti}$ versus $\mathrm{Nb} / \mathrm{Y}$ diagram (Fig. 2.8a). On the $\mathrm{FeO}_{\mathrm{T}}$-total alkalis-MgO (AFM) diagram, the $\mathrm{Fe}$ - to $\mathrm{Mg}$-rich mafic volcanic rocks show a tholeiitic geochemical affinity (Fig. 2.8b). Most of the $\mathrm{Zr} / \mathrm{Y}$ ratios (3.9-10.3) are within the range of modern tholeiitic basalts (see Barrett and MacLean, 1994). The Nb/Ta (14-19) ratios are subchondritic to chondritic (Table 2.1).

The mafic volcanic rocks possess near-flat REE patterns at 1 to 10 times $\mathrm{N}$ MORB (Fig. 2.10a). La/ $\mathrm{Sm}_{\mathrm{cn}}(1.25-2.28)$ and $\mathrm{Gd} / \mathrm{Yb}_{\mathrm{cn}}$ (1.45-2.11) ratios show considerable variations. Cerium and $\mathrm{Eu}$ anomalies are minimal, but $\mathrm{Ta}$ and $\mathrm{Nb}$ $\left(\mathrm{Nb} / \mathrm{Nb}^{*}=0.15-0.44\right)$ show salient negative anomalies on the $\mathrm{N}$-MORB-normalized diagram (Fig. 2.11a). They are marked by the following geochemical features: (1) variably negative $\mathrm{Zr} \quad\left(\mathrm{Zr} / \mathrm{Zr}^{*}=0.61-0.93\right)$ anomalies; (2) small positive $\mathrm{Ce}$ $\left(\mathrm{Ce} / \mathrm{Ce}^{*}=1.01-1.08\right)$ anomalies; (3) slightly variable $\mathrm{Eu}(\mathrm{Eu} / \mathrm{Eu} *=0.81-1.13)$ and highly variable $\mathrm{Ti}\left(\mathrm{Ti} / \mathrm{Ti}{ }^{*}=0.48-1.74\right)$ anomalies; and (4) strong enrichments of $\mathrm{Th}$ with respect to La (Figs. 2.11a and 2.12a; Table 2.1).

\subsubsection{Intermediate volcanic rocks}

Intermediate volcanic rocks only account for a small volume of all the volcanicrelated lithogies in the BVL greenstone belt. They are characterized by 59-67 wt.\% $\mathrm{SiO}_{2}, 0.65-2.65$ wt. $\% \mathrm{MgO}, 2.7-11.6$ wt. $\% \mathrm{Fe}_{2} \mathrm{O}_{3}, 14.6-23.6$ wt. $\% \mathrm{Al}_{2} \mathrm{O}_{3}$, and 0.7-5.6 wt.\% $\mathrm{CaO}$ (Figs. 2.8-2.10; Table 2.1). Mg-numbers range from 26 to 40. Like the mafic volcanic rocks, they have a sub-alkaline composition and a tholeiitic affinity (Figs. 2.8a, b). Two samples (BVL2013-026 and 027) show significantly higher MgO 
(8.1-9.4 wt.\%) and Mg-numbers (60-65), with 62-66 wt.\% $\mathrm{SiO}_{2}$ values than the other three samples (BVL2013-003, 012 and 013) (Table 2.1). The BVL intermediate volcanic rocks have $0.69-1.23$ wt. $\% \mathrm{TiO}_{2}, 11-25$ ppm Sc , 60-118 ppm Ni, and 10-190 ppm Cr (Figs. 2.9 and 2.10; Table 2.1). On the chondrite- and N-MORB-normalized diagrams, they are defined by the following features: (1) variably enriched LREE and flat to depleted HREE patterns $\left(\mathrm{La} / \mathrm{Sm}_{\mathrm{cn}}=1.59-4.79 ; \mathrm{Gd} / \mathrm{Yb}_{\mathrm{cn}}=1.06-2.69\right) ;(2)$ strong negative $\mathrm{Nb}\left(\mathrm{Nb} / \mathrm{Nb}^{*}=0.07-0.21\right)$ and $\mathrm{Ti}(\mathrm{Ti} / \mathrm{Ti} *=0.23-0.63)$; (3) moderately negative Eu anomalies $(\mathrm{Eu} / \mathrm{Eu} *=0.46-0.87)$; and (4) negative to positive $\mathrm{Zr}(\mathrm{Zr} / \mathrm{Zr} *=0.67-1.05)$ anomalies (Figs. 2.11 and 2.12; Table 2.1).

\subsubsection{Intermediate to felsic volcaniclastic rocks}

In the field, these rocks have gradational appearance between intermediate and felsic volcaniclastic rocks. Thus, they are called intermediate to felsic rocks. These rocks have moderate variations in $\mathrm{SiO}_{2}$ (66-78 wt.\%), $\mathrm{MgO}$ (0.53-3.40 wt.\%), $\mathrm{CaO}$ (0.09-5.24 wt.\%), $\mathrm{Al}_{2} \mathrm{O}_{3}(10.4-16.2$ wt.\%), $\mathrm{Nb}(10.9-19.2 \mathrm{ppm}), \mathrm{Y}(27-90 \mathrm{ppm})$ and $\mathrm{Zr}$ (270-570 ppm) contents (Figs. 2.8-2.10; Table 2.1). Compositionally, they are dacite to rhyodacite (Fig. 2.8a), and reveal a transition from a tholeiitic affinity to a calcalkaline affinity (Fig. 2.8b). Despite their larger negative Ti anomalies (Ti/Ti*=0.050.20), the intermediate to felsic volcanic rocks display chondrite- and N-MORBnormalized patterns that are similar to those of the intermediate rocks (Figs. 2.11 and 2.12; Table 2.1).

\subsubsection{Felsic porphyritic rocks}

The felsic porphyritic rocks in the BVL greenstone belt have similar chemical compositions, and can be geochemically classified as rhyolites (Fig. 2.8a). The 
majority of samples show a transition from tholeiitic to calc-alkaline affinities (Fig. 2.8b). They are characterized by high $\mathrm{SiO}_{2}$ (76-82 wt. \%), but low $\mathrm{Cr}$ (13-36 ppm), Ni (20-43 ppm), $\mathrm{TiO}_{2}(0.26-0.43$ wt.\%), $\mathrm{MgO}(0.12-1.24$ wt.\%), and $\mathrm{Sc}(2-8 \mathrm{ppm})$ concentrations (Figs. 2.8-2.10; Table 2.1). Based on the $\mathrm{Zr} / \mathrm{Y}$ ratios (3.5-10.4) versus Y (88-115) abundance, they are classified as FII rhyolites (cf., Lesher et al., 1986; Barrie et al., 1993; Barrett and MacLean, 1994; Hart et al., 2004).

On chondrite- and N-MORB-normalized trace element diagrams, the felsic porphyritic volcanic rocks are characterized by: (1) moderately enriched LREE patterns, at $10-50$ times N-MORB $\quad\left(\mathrm{La} / \mathrm{Sm}_{\mathrm{cn}}=1.78-2.32 ; \quad \mathrm{Gd} / \mathrm{Yb}_{\mathrm{cn}}=1.02-1.32\right.$; $\left.\mathrm{La} / \mathrm{Yb}_{\mathrm{cn}}=2.17-3.17\right)$; (2) variably negative to positive $\mathrm{Zr}$ anomalies $\left(\mathrm{Zr} / \mathrm{Zr}{ }^{*}=0.72\right.$ 1.29); (3) strongly negative $\mathrm{Nb}\left(\mathrm{Nb} / \mathrm{Nb}^{*}=0.16-0.48\right)$; and (4) pronounced negative $\mathrm{Ti}$ anomalies $\left(\mathrm{Ti} / \mathrm{Ti}{ }^{*}=0.04-0.08\right)($ Figs. 2.11 and 2.12; Table 2.1).

\subsubsection{Gabbros}

Gabbros are compositionally variable at 45-52 wt.\% $\mathrm{SiO}_{2}, 0.82-2.69$ wt.\% $\mathrm{TiO}_{2}$, 11.4-18.2 wt. $\% \mathrm{Al}_{2} \mathrm{O}_{3}, 13.6-26.1$ wt. $\% \mathrm{Fe}_{2} \mathrm{O}_{3}, 4.3-8.1$ wt. $\% \mathrm{MgO}$, and 6.0-10.8 wt. \% $\mathrm{CaO}$. Large variations in $\mathrm{Cr}$ (11-203 ppm), V (300-800 ppm), Zr (34 -220 ppm) and LREE (e.g., La=2.9-14.7 ppm), and moderate variations in Ni (117-197 ppm) and Y (14.8-30.9 ppm) contents. The ratios of $\mathrm{Al}_{2} \mathrm{O}_{3} / \mathrm{TiO}_{2}$ (4-19) are subchondritic, whereas the ratios of $\mathrm{Nb} / \mathrm{Ta}(14-29), \mathrm{Ti} / \mathrm{Zr}(60-282)$, and $\mathrm{Zr} / \mathrm{Y}$ (1.6-7.1) are subchondritic to superchondritic (Table 2.1).

The gabbros display the following trace element characteristics: (1) near-flat to variably enriched LREE patterns $\left(\mathrm{La} / \mathrm{Sm}_{\mathrm{cn}}=0.93-2.36 ; \mathrm{La} / \mathrm{Yb}_{\mathrm{cn}}=0.97-4.12\right)$ and flat to depleted HREE patterns $\left(\mathrm{Gd} / \mathrm{Yb}_{\mathrm{cn}}=1.06-2.48\right)$; (2) minor positive $\mathrm{Ce}\left(\mathrm{Ce} / \mathrm{Ce} e^{*}=1.01\right.$ 1.16) anomalies; (3) moderately negative $\mathrm{Eu}$ anomalies $\left(\mathrm{Eu} / \mathrm{Eu}^{*}=0.60-0.96\right)$; (4) 
negative to positive $\mathrm{Zr}(\mathrm{Zr} / \mathrm{Zr} *=0.25-1.25)$ and $\mathrm{Ti}\left(\mathrm{Ti} / \mathrm{Ti}{ }^{*}=0.87-1.17\right)$ anomalies; and (5) large negative $\mathrm{Nb}\left(\mathrm{Nb} / \mathrm{Nb}^{*}=0.09-0.41\right)$ anomalies (Figs. 2.11 and 2.12; Table 2.1).

\subsubsection{Siliciclastic sedimentary rocks}

Siliciclastic sedimentary samples from the Seine group are defined as finegrained sandstones based on the analyses of their grain sizes under microscope (Fig. 2.5). They are distinguished by high $\mathrm{SiO}_{2}$ (64.2-73.0 wt.\%), $\mathrm{Al}_{2} \mathrm{O}_{3}(13.2-18.6$ wt. \%), LOI (2.9-4.8 wt.\%) and low MgO (0.92-0.98 wt.\%) concentrations (Table 2.1). These sedimentary rocks show the following characteristics on the chondrite- and N-MORBnormalized trace element diagrams: (1) strongly fractionated REE patterns $\left(\mathrm{La} / \mathrm{Sm}_{\mathrm{cn}}=4.6-4.8 ; \mathrm{La} / \mathrm{Yb}_{\mathrm{cn}}=23.6-27.3\right) ;$ (2) large negative $\mathrm{Nb}(\mathrm{Nb} / \mathrm{Nb} *=0.05-0.08)$ and $\mathrm{Ti}\left(\mathrm{Ti} / \mathrm{Ti}^{*}=0.20-0.34\right)$ anomalies; and (3) moderately negative $\mathrm{Zr}\left(\mathrm{Zr} / \mathrm{Zr}{ }^{*}=0.61\right.$ 0.68) anomalies (Figs. 2.10f and 2.11f; Table 2.1).

\subsubsection{Ottertail Lake granite}

The Ottertail Lake granite is characterized by $65.5-74.8$ wt.\% $\mathrm{SiO}_{2}, 3.9-4.5$ wt.\% $\mathrm{Na}_{2} \mathrm{O}$, 3.6-4.6 wt.\% $\mathrm{K}_{2} \mathrm{O}$ and low volatile contents (0.4-0.7 wt.\%) compared with rock units in the BVL greenstone belt (Table 2.2). The Rittmann Serial Index $[\sigma=$ $\left.\left(\mathrm{N}_{2} \mathrm{O}+\mathrm{K}_{2} \mathrm{O}\right)^{2} /\left(\mathrm{SiO}_{2}-43\right)\right]$ (Rittmann, 1957) is consistent with a calc-alkaline affinity $(\sigma<3.3)$. The $\mathrm{Al}_{2} \mathrm{O}_{3}, \mathrm{~N}_{2} \mathrm{O}, \mathrm{K}_{2} \mathrm{O}$ and $\mathrm{CaO}$ contents are consistent with metaluminous to slightly peraluminous affinities (Table 2.2).

The Ottertail granite has the following trace element characteristics: (1) strong fractionation of REE $\left(\mathrm{La} / \mathrm{Sm}_{\mathrm{cn}}=4.4-8.6\right.$; $\left.\mathrm{La} / \mathrm{Yb}_{\mathrm{cn}}=14.3-35.5\right)$; (2) negative anomalies of $\mathrm{Eu}\left(\mathrm{Eu} / \mathrm{Eu}^{*}=0.72-0.83\right), \mathrm{Zr}\left(\mathrm{Zr} / \mathrm{Zr}^{*}=0.6-0.9\right), \mathrm{Nb}\left(\mathrm{Nb} / \mathrm{Nb}^{*}=0.04-0.13\right)$, and $\mathrm{Ti}$ $\left(\mathrm{Ti} / \mathrm{Ti}^{*}=0.11-0.22\right)($ Figs. 2.11 and 2.12; Table 2.2). Overall, the trace element patterns 
of the granites are similar to the siliciclastic sedimentary rocks from the Seine Group (Figs. 2.11 and 2.12; Table 2.2). They plot in the VAG+syb-COLG and VAG fields on $\mathrm{Y}$ versus $\mathrm{Nb}$ and $\mathrm{Y}+\mathrm{Nb}$ versus $\mathrm{Rb}$ tectonic discrimination diagrams, respectively (Fig. 2.13).

\subsubsection{Radiogenic isotopes}

\subsubsection{Sm-Nd isotopes}

All rock types, including mafic volcanic rocks $(\varepsilon \mathrm{Nd}=+1.4$ to +3.5$)$, gabbros $\left(\varepsilon_{\mathrm{Nd}}=\right.$ +1.5 to +3.8$)$, intermediate volcanic rocks $(\varepsilon N d=+3.1$ to +4.0$)$, intermediate to felsic volcaniclastic rocks $(\varepsilon \mathrm{Nd}=+0.8$ to 2.5$)$, and porphyritic felsic volcanic rocks $(\varepsilon \mathrm{Nd}=$ +2.0 to +2.6$)$ have variably positive initial $(2720 \mathrm{Ma}) \varepsilon \mathrm{Nd}$ values, and display similar ${ }^{147} \mathrm{Sm} /{ }^{144} \mathrm{Nd}$ ratios (Table 2.4). Depleted mantle model ages range from 2.76 to 3.18 Ga (Table 2.4). All samples have yield an errorchron age of $2921 \pm 200 \mathrm{Ma}$ $(\mathrm{MSWD}=170)$ (Fig. 2.14). Mafic rocks (mafic volcanic rocks and gabbros) together have yielded an errorchron age of 2987 \pm 260 Ma (MSWD=63) (Fig. 2.14), whereas the intermediate to felsic rocks have given an age of 2763 $\pm 480 \mathrm{Ma}(\mathrm{MSWD}=218$ ).

The majority of major and elements do not show any significant correlations with ${ }^{143} \mathrm{Nd} /{ }^{144} \mathrm{Nd}$ ratios (Fig. 2.15). On some trace element diagrams (e.g., La, Y, Zr, Nb, $\mathrm{Nd}$ ), the mafic rocks (e.g., mafic volcanic rocks and gabbros) and intermediate to felsic volcanic and volcaniclastic rocks plot as separate groups (Fig. 2.15).

\subsubsection{Pb isotopes}

All rock types in the BVL greenstone belt display large variations in ${ }^{206} \mathrm{~Pb} /{ }^{204} \mathrm{~Pb}$, ${ }^{207} \mathrm{~Pb} /{ }^{204} \mathrm{~Pb}$, and ${ }^{208} \mathrm{~Pb} /{ }^{204} \mathrm{~Pb}$ isotope ratios (Table 2.5). A porphyritic rhyolite sample (BVL2013-030) has the highest ${ }^{206} \mathrm{~Pb} /{ }^{204} \mathrm{~Pb}$ (60.672), ${ }^{207} \mathrm{~Pb} /{ }^{204} \mathrm{~Pb}$ (23.404), and 
${ }^{208} \mathrm{~Pb} /{ }^{204} \mathrm{~Pb}(85.100)$ values, whereas gabbroic sample BVL2013-025 exhibits the lowest ${ }^{206} \mathrm{~Pb} /{ }^{204} \mathrm{~Pb}(13.805),{ }^{207} \mathrm{~Pb} /{ }^{204} \mathrm{~Pb}(14.606)$, and ${ }^{208} \mathrm{~Pb} /{ }^{204} \mathrm{~Pb}$ (33.655) values in the belt (Table 2.5). All rock types have collectively yielded an errorchron age of $2661 \pm 60 \mathrm{Ma}(\mathrm{MSWD}=880$ ) (Fig. 2.14b). The mafic volcanic rocks and the gabbros together have yielded an age of 2725 \pm 83 Ma (MSWD=63) (Fig. 2.14c), whereas the intermediate to felsic rocks have given an age of $2661 \pm 100 \mathrm{Ma}$ (MSWD=1573). There are no obvious correlations between rock types and ${ }^{206} \mathrm{~Pb} /{ }^{204} \mathrm{~Pb}$ ratios for most major and trace element concentrations (Fig. 2.16).

\subsubsection{Sr isotopes}

${ }^{87} \mathrm{Sr} /{ }^{86} \mathrm{Sr}$ ratios display large variations in mafic volcanic rocks $(0.701512-$ 0.730744), intermediate to felsic volcaniclastic rocks $(0.722065-0.940511)$ and porphyritic felsic volcanic rocks $(0.732422-1.011538)$, whereas they have smaller ranges in gabbros $(0.701481-0.705468)$ and intermediate volcanic rocks $(0.724179-$ 0.724386) (Table 2.6). As a group, the gabbros have the lowest whereas the porphyritic rhyolites have the highest ${ }^{87} \mathrm{Sr} /{ }^{86} \mathrm{Sr}$ values (Table 2.6). Initial ${ }^{87} \mathrm{Sr} /{ }^{86} \mathrm{Sr}$ ranges from 0.625650 to 0.769642 . The $\mathrm{BVL}$ greenstone belt rocks have yielded an ${ }^{87} \mathrm{Rb} /{ }^{86} \mathrm{Sr}-{ }^{87} \mathrm{Sr} /{ }^{86} \mathrm{Sr}$ errorchron age of $2229 \pm 350 \mathrm{Ma}(\mathrm{MSWD}=59)$ (Fig. 2.14d). Like $\mathrm{Nd}$ and $\mathrm{Pb}$ isotopes, $\mathrm{Sr}$ isotopes do not display strong correlations with major and trace element concentrations (Fig. 2.17).

\subsection{Discussion}

\subsubsection{Effects of metamorphism on element mobility}

Metamorphic alteration has a strong impact on element mobility in Archean greenstone belts (Condie et al., 1977; Rubin, 1993; Polat and Hoffmann, 2003; Polat 
et al., 2003, 2007). All major lithologic units of the BVL greenstone belt have undergone polyphase deformation and ubiquitous greenschist metamorphism that modified primary textures and minerals (Figs. 2.2-2.5). It is therefore necessary to understand the effects of alteration on the geochemical composition of the BVL greenstone belt before considering its petrogenetic origin and geodynamic setting. Altered samples are identified by the presence of $\mathrm{Ce}$ anomalies $(\mathrm{Ce} / \mathrm{Ce} *<0.9$ or $\mathrm{Ce} / \mathrm{Ce} *>1.1)$ on chondrite-normalized REE diagrams and carbonate and silica (quartz) enrichment $>2 \%$ (Table 2.1) (see Polat and Hoffman, 2003). These samples are not used in petrogenetic interpretation.

Widespread occurrence of chlorite and epidote contributes to the enrichment of volatile phases (LOI: 3.37-9.21 wt.\%) in the Bad Vermilion Lake greenstone belt, suggesting that they underwent extensive hydrothermal alteration (Figs. 2.2-2.5; Table 2.1), as seen in other Archean greenstone belts (Ludden et al., 1982; Xie et al., 1993; Kerrich et al., 1999; Polat et al., 2002; Polat and Hoffmann, 2003; Polat, 2009). Elements that were most resistant to alteration during metamorphism are HFSE (e.g., $\mathrm{Nb}, \mathrm{La}-\mathrm{Lu}$ ) and transition metals (e.g. Sc, Ni), since they show moderate correlations with $\mathrm{Zr}$ on variation diagrams (Figs. 2.9 and 2.10).

Large scatter on the $\mathrm{Sm}-\mathrm{Nd}, \mathrm{Pb}-\mathrm{Pb}$ and $\mathrm{Rb}-\mathrm{Sr}$ regression diagrams and isotopic ratios is consistent with the mobility of these elements in some samples (Fig. 2.14; Tables 2.4-2.6). The $2225 \pm 350 \mathrm{Ma}{ }^{87} \mathrm{Rb} /{ }^{86} \mathrm{Sr}-{ }^{87} \mathrm{Sr} /{ }^{86} \mathrm{Sr}$ errorchron age yielded by the BVL greenstone belt is significantly lower than the zircon $\mathrm{U}-\mathrm{Pb}$ ages $(2722 \pm 11$ and $2724 \pm 23 \mathrm{Ma}$ ) from the porphyritic rhyolites, suggesting that the $\mathrm{Rb}-\mathrm{Sr}$ isotope system was mainly open during the hydrothermal alteration. In contrast, the ${ }^{147} \mathrm{Sm} /{ }^{144} \mathrm{Nd}-$ ${ }^{143} \mathrm{Nd} /{ }^{144} \mathrm{Nd}(2921 \pm 200 \mathrm{Ma})$ and ${ }^{206} \mathrm{~Pb} /{ }^{204} \mathrm{~Pb}-{ }^{207} \mathrm{~Pb} /{ }^{204} \mathrm{~Pb}(2661 \pm 60 \mathrm{Ma})$ plots have yielded errorchron ages that are closer to zircon $\mathrm{U}-\mathrm{Pb}$ ages of the porphyritic rhyolites, 
indicating that the $\mathrm{Sm}-\mathrm{Nd}$ and $\mathrm{U}-\mathrm{Pb}$ isotope systems were less susceptible to metamorphic recrystallization than the $\mathrm{Rb}-\mathrm{Sr}$ system. Given that the $\mathrm{U}-\mathrm{Pb}$ system among all three isotope systems has yielded the closest regression ages $(2661 \pm 60 \mathrm{Ma}$ for all rocks; $2725 \pm 83$ Ma for mafic rocks) to the zircon ages, this isotope system appears to be the least affected by metamorphism.

\subsubsection{New age constraints and their implications}

Except for one inherited zircon grain with a ${ }^{207} \mathrm{~Pb} /{ }^{206} \mathrm{~Pb}$ age of $2808 \pm 24 \mathrm{Ma}$, magmatic zircons in sample BVL2013-030 have given a mean crystallization age of 2722 \pm 11 Ma (Fig. 2.5a). Similarly, magmatic zircons from sample BVL2013-034 have yielded a crystallization age of $2724 \pm 23$ Ma (Fig. 2.5c). Therefore, these ages are interpreted as the crystallization of the porphyritic rhyolites in the BVL greenstone belt. These ages agree with the previously reported zircon age $(\sim$ ca. $2727 \pm 1 \mathrm{Ma}$; Davis et al., 1989) on the felsic volcanic rocks in the BVL greenstone belt, reflecting the timing of the bimodal volcanism in the study area. The $2725 \pm 83 \mathrm{Ma}{ }^{206} \mathrm{~Pb} /{ }^{204} \mathrm{~Pb}-$ ${ }^{207} \mathrm{~Pb} /{ }^{204} \mathrm{~Pb}$ errorchron age yielded by the mafic rocks (gabbros and basalts) can also be considered as the approximate age of the belt. The BVL greenstone belt and the anorthosite complex are intruded by the $2716 \pm 18$ Ma granitic rocks, constraining the minimum age of the BVL greenstone belt (Zhou et al., 2015).

Four structureless and homogenous zircons with lower ${ }^{207} \mathrm{~Pb} /{ }^{235} \mathrm{U}$ and ${ }^{206} \mathrm{~Pb} /{ }^{238} \mathrm{U}$ ratios in sample BVL 2013-031 have much younger ${ }^{207} \mathrm{~Pb} /{ }^{206} \mathrm{~Pb}$ ages ranging from $377 \mathrm{Ma}$ to $2604 \mathrm{Ma}$ (Table 2.3); these ages may be attributed to $\mathrm{Pb}$ loss during later tectonothermal events.

The Ottertail Lake granite (Fig. 2.7d) has yielded a relatively concordant crystallization age of ca. $2664 \mathrm{Ma}$, which marks the termination of deposition of 
volcanic and sedimentary rocks in the BVL greenstone belt. Given that the majority of tholeiitic to calc-alkaline volcanic rocks in the western Wabigoon terrane were deposited between 2745 and 2720 Ma (Davis et al., 1988; Corfu and Davis, 1992), it is speculated that the cessation of the volcanism in the BVL greenstone belt marks the migration of arc magmatism farther south in the southern boundary of the West Wabigoon terrane. The majority of the large TTG intrusions in the western Wabigoon terrane were emplaced into the bimodal volcanic association between $2735 \mathrm{Ma}$ and 2710 Ma (Davis and Edwards, 1982, 1986). Since Laurentian granitoids are geochemically similar to the spatially associated rhyolites (Ashwal et al., 1983), both the granitoids and the felsic volcanic rocks can be treated as a proxy for the early synvolcanic tonalitic-dioritic-gabbroic batholith (ca. 2735-2720 Ma; Davis and Edwards, 1982, Corfu and Davis, 1992; Whalen et al., 2004) in the western Wabigoon terrane. Because the Bad Vermilion Lake anorthosite complex is intruded by $2716 \mathrm{Ma}$ and 2649 Ma old granitic rocks (Zhou et al., 2015), it can be considered as contemporaneous with the bimodal volcanism in the BVL greenstone belt. Deposition of the juvenile Coutchiching Group and the immature Seine sedimentary rocks (conglomerates and sandstone) mark rapid uplifting and erosion in the region.

\subsubsection{Source characteristics and tectonic setting of the BVL greenstone belt}

Despite the effect of metamorphism, the $\mathrm{Nd}$ isotope compositions $(\varepsilon \mathrm{Nd}=+0.8$ to +4.0 ) of the BVL greenstone belt rocks are similar to those of Neoarchean greenstone belts in other parts of the Superior Province (see Vervoort et al., 1994; Stevenson, 1995; Henry et al., 1998; Polat and Kerrich, 2002; Polat, 2009; Lodge et al., 2015), consistent with a depleted mantle source. The N-MORB-normalized trace element patterns (Fig. 2.12) indicate that the Neoarchean Bad Vermilion Lake volcanic rocks 
were derived from a subarc mantle wedge (see Pearce and Peate, 1995; Murphy, 2007). Flat to slightly depleted HREE patterns (Fig. 8a-c) are consistent with a shallow $(<90 \mathrm{~km}$ ) mantle source (see Xie et al., 1993; Polat et al., 2005; Van Westrenen et al., 2001). Mafic rocks (basalts and gabbros) and intermediate and felsic rocks plot in two different fields on ${ }^{143} \mathrm{Nd} /{ }^{144} \mathrm{Nd}$ versus $\mathrm{La}, \mathrm{Nd}, \mathrm{Nb}$ and $\mathrm{Y}$; this may reflect two different sources for the BVL greenstone belt rocks (Fig. 2.15).

The following observations suggest that the Bad Vermilion Lake volcanic rocks share the geochemical characteristic of Phanerozoic bimodal volcanic arcs: (1) the Bad Vermilion Lake volcanic rocks show a magmatic evolution trend from basalt to rhyolite on the $\mathrm{SiO}_{2}$ versus $\mathrm{Zr} / \mathrm{TiO}_{2}$ diagram (Fig. 2.8a), such trend is analogous to volcanic rocks in Tonga trench (Ewart and Bryant, 1972; Ewart et al., 1973); (2) on the AFM diagram, they show a transition from tholeiitic to calc-alkaline series (Fig. $2.8 b$ ); (3) the $\mathrm{Nb} / \mathrm{Ta}$ (12 to 19 ) ratios in the mafic volcanic rocks are similar to those in the modern arc and backarc systems (see Münker, 1998); (4) on the Th/Yb versus $\mathrm{Nb} / \mathrm{Yb}$ binary diagram (not shown), the mafic volcanic rocks show geochemical similarities to Cenozoic oceanic island arc basalts (cf., Pearce, 2008); and (5) the mafic samples with lower contents of trace elements $\left(\sum \mathrm{REE}=10-30 \times\right.$ chondrite $)$ have higher Mg-number (40-60); while those with higher contents of trace elements $\left(\sum \mathrm{REE}=10-30 \times\right.$ chondrite $)$ possess lower $\mathrm{Mg}$-number (20-40), reflecting various degrees of fractional crystallization or partial melting (cf., Greene, 2006).

The Bad Vermilion Lake felsic rocks share the negative $\mathrm{Eu}(\mathrm{Eu} / \mathrm{Eu} *=0.46-0.84)$ and $\mathrm{Ti}\left(\mathrm{Ti} / \mathrm{Ti}{ }^{*}=0.03-0.08\right)$ anomalies of felsic volcanic rocks in the Winston Lake greenstone belt, Wawa subprovince, which have been interpreted as arc-back arc volcanic rocks (Polat, 2009; Kerrich et al., 2008; Lodge et al., 2014, 2015). 


\subsubsection{Source characteristics of the Ottertail Lake granite}

The Ottertail Lake granite has strongly fractionated REE patterns $\left(\mathrm{La} / \mathrm{Sm}_{\mathrm{cn}}=4.4-\right.$ 8.6, $\mathrm{Gd} / \mathrm{Yb}_{\mathrm{cn}}=1.7-3.2$ ) and negative $\mathrm{Nb}, \mathrm{Ta}$, Ti, and Eu anomalies (Figs. 2.10 and 2.11). The $\mathrm{Y}$ versus $\mathrm{Nb}$ and $\mathrm{Y}+\mathrm{Nb}$ versus $\mathrm{Rb}$ tectonic discrimination diagrams suggest that the Ottertail Lake granite (Fig. 2.13) originated in a syn-collisional arc setting at about 2664 Ma. It is compositionally akin to Archean granodiorite-granite-monzogranite (GGM)-type post-kinematic granitoids, which are usually interpreted as product of partial melting of Archean TTG crust and associated sediments in an extensional environment following a major orogeny (cf., Hart et al., 1981; Robb and Anhaeusser, 1983; Sylvester, 1994).

\subsubsection{Geodynamic and petrogenetic implications}

The BVL greenstone belt volcanic association is characterized by a bimodal tholeiitic to calc-alkaline suite displaying subduction geochemical signatures $\left(\mathrm{Nb} / \mathrm{Nb}^{*}=0.07-0.48\right)$. The spatially associated layered gabbros and anorthosite complex also have subduction zone geochemical signatures $\left(\mathrm{Nb} / \mathrm{Nb}^{*}=0.04-0.99\right)$ (Zhou et al., 2015). The field relationship (Figs. 2.2 and 2.3) and subduction zone geochemical signatures of all rock associations (Fig. 2.12) are consistent with the tectonic evolution of the region at a convergent plate margin (e.g., Percival et al., 2012).

Ophiolites are defined as fragments of oceanic crust and uppermost mantle, recording the opening and closure of ancient oceans in the framework of the Wilson cycles of plate tectonics (Şengör, 1990; Dilek and Furnes, 2014; Furnes et al., 2015). According to the Penrose definition, the stratigraphic sequence of ophiolites include, from bottom to top, mantle peridotites, layered gabbros, sheeted dykes, pillow basalts 
and sedimentary covers (Anonymous, 1972). However, the Penrose definition of ophiolite has major limitations in defining ophiolites in the Archean rock record that is typically characterized by multiple phases of deformation, metamorphism and intrusion (Kusky, 2004; Kusky et al., 2014; Şengör and Natal'in, 2004; Dilek and Polat, 2008; Dilek and Furnes, 2011; Furnes et al., 2015). Given the inadequacy of the Penrose ophiolite definition in Precambrian orogenic belts, Dilek and Furnes (2011) redefined ophiolite as "suites of temporally and spatial associated ultramafic to felsic rocks related to separate melting episodes and processes of magmatic differentiation in particular tectonic environments". Dilek and Furnes $(2011,2014)$ reclassified ophiolites as: (1) subduction-related ophiolites originating in backarc, forearc and arc tectonic settings; and (2) subduction-unrelated ophiolites forming in rifted continental margins, mid-ocean ridges and oceanic plateaus. Lithological and geochemical characteristics of the BVL greenstone are consistent with being a subduction-related Archean ophiolite.

The Seine Group is bounded by unconformity with the underlying Keewatin and Coutchiching sequence. It is a Timiskaming-type deposit dominated by conglomerates and sandstones and siltstone with a maximum deposition age of around $2696 \mathrm{Ma}$ (Wood, 1980; Davis et al., 1989), implying a shallow water alluvial-fan terrestrial depositional environment (Hyde, 1980; Mueller and Corcoran, 1998). Field observations suggest that the boulders and pebbles in the Timiskaming deposit (Figs. 2.2 and 2.3) were originated from the BVL greenstone belt and associated granitic rocks, suggesting that the region underwent uplift and erosion during Timiskaming deformation. Similarly, the trace element compositions of the Seine Group sandstones (Figs. 2.11 and 2.12) are similar to the volcanic and granitic rocks in the area, suggesting a proximal source area. 
The BVL greenstone belt originated during the Central Superior orogeny (at 2710-2700 Ma; Percival et al., 2006a). Based on the tectonic implications of each lithologic unit in the BVL region, a life cycle of intra-oceanic setting can be summarized as follows: (1) rifting of the Winnipeg River-Marmion terrane contributed to the build-up of western Wabigoon mafic oceanic crust spanning from 2775 to $2720 \mathrm{Ma}$ (see Blackburn et al., 1991); (2) formation of the island arc bimodal volcanic association as well as spatially associated anorthosite and TTGs were mainly produced around ca. $2720 \mathrm{Ma}$ due to oblique subduction of the oceanic western Wabigoon terrane underneath the oceanic crust of the Winnipeg River terrane (see Percival et al., 2006a); (3) the immature clastic sediments (e.g., the Coutchiching Group) were likely deposited in a marginal ocean basin or extended forearc basin between 2720 and $2710 \mathrm{Ma}$ (see Percival et al., 2012); and (4) collision between the western Wabigoon terrane and the continental Winnipeg River terrane generated the oceanic-island-arc complex between 2710 and 2700 Ma (Corfu, 1988; Davis and Smith, 1991; Ayer and Dostal, 2000), which not only produced a large amount of intermediate volcanic rocks (Savant-Sturgeon greenstone belt; Sanborn-Barrie and Skulski, 2006 and reference therein), but also caused uplifting, erosion, deformation and local stratigraphic inversion in the BVL greenstone belt (Davis et al., 1989; Poulsen et al., 1980).

Due to the ca. 2690 Ma accretion of the Quetico sedimentary prism on the southern margin of the western Wabigoon terrane (Percival, 1989; Percival and Williams, 1989; Williams, 1990; Zaleski et al., 1999), the relative location of the BVL greenstone belt was transformed from the interior of the west Wabigoon terrane to the boundary between the Wabigoon and Quetico subprovinces.

The Ottertail Lake granite intruded in an extensional environment after the 
Minnesotan (2.68 Ga) orogeny, when all the belt-like subprovinces had been assembled to form the Superior Province (Percival, 2006a, b, 2012). Collectively, the geodynamic processes that formed the supracrustal rocks in the BVL greenstone belt are consistent with an allochthonous rather than autochthonous origin, resulting from modern-style plate tectonic processes in the Mesoarchean to Neoarchean (see Williams, 1990; Williams et al., 1991; Percival et al., 2004; Backeberg et al., 2014; Kusky et al., 2014).

\subsection{Conclusions}

On the basis of new field observations, zircon U-Pb ages, whole-rock major and trace element, and $\mathrm{Nd}, \mathrm{Pb}$ and $\mathrm{Sr}$ isotope data, the following conclusions are drawn for the Neoarchean Bad Vermilion Lake (BVL) greenstone belt and the spatially associated Ottertail Lake granite and the Timiskaming type Seine Group sedimentary rocks:

1. The Neoarchean (ca. $2720 \mathrm{Ma}$ ) BVL greenstone belt is composed of subductionderived tholeiitic to calc-alkaline volcanic and volcaniclastic rocks including basalts, andesites and rhyolites. On the basis of new ophiolite classifications (Dilek and Furnes, 2011; Furnes et al., 2015), the BVL greenstone belt is defined as a subduction-related ophiolite. Positive initial $\varepsilon N d$ values $(+0.8$ to +4.0$)$ in the BVL greenstone belt lithologies are consistent with a long-term depleted mantle source or sources. These $\varepsilon N d$ values are similar to those in other Neoarchean greenstone belts in the Superior Province.

2. Zircon U-Pb ages indicate that the porphyritic rhyolites in the BVL greenstone belt formed at ca. $2725 \mathrm{Ma}$, constraining the age of the belt and subduction zone 
processes, northerly subduction of oceanic crust beneath the Western Wabigoon and Marmion terrane in the region.

3. Based on the U-Pb zircon dating, the BVL greenstone belt is intruded by 2716 , 2664 and $2649 \mathrm{Ma}$ granitic rocks and overlain unconformably by $2696 \mathrm{Ma}$ Timiskaming-type clastic sedimentary rocks.

4. The emplacement of the late- to post-tectonic Ottertail Lake granite at ca. $2664 \mathrm{Ma}$ marked the end of accretionary tectonic process between the Western Wabigoon and Marmion, Quetico and Wawa-Abitibi terranes. High $\mathrm{SiO}_{2}(65-75$ wt.\%) and $\mathrm{K}_{2} \mathrm{O}(3.9-4.5$ wt. $\%)$ contents, negative $\mathrm{Eu}$ anomalies $(\mathrm{Eu} / \mathrm{Eu} *=0.72-0.83)$, and recycled older zircons (ca. $2868 \mathrm{Ma}$ ) in the Ottertail Lake granitic rocks suggest that they were derived from older felsic rocks. The origin of these rocks is attributed to an extensional tectonic regime following the collision between the Western Wabigoon and Marmion, Quetico and Wawa-Abitibi terranes.

5. Petrographic observations, major and trace element, and $\mathrm{Nd}, \mathrm{Pb}$ and $\mathrm{Sr}$ isotope data indicate that the BVL greenstone belt underwent intense hydrothermal alteration, resulting in mobilization of many elements (e.g., $\mathrm{K}, \mathrm{Rb}, \mathrm{Ba}, \mathrm{Sr}, \mathrm{Na}$, and $\mathrm{Pb}$ ). The REE (La-Lu), HFSE (e.g., Nb, Zr, Y), and some transitional metals (e.g., Ni and Sc) were among the least mobile elements. Hydrothermal alteration appears to have disturbed the $\mathrm{Rb}-\mathrm{Sr}$ isotope system in all samples, and $\mathrm{Sm}-\mathrm{Nd}$ and $\mathrm{U}-\mathrm{Pb}$ isotope systems in some samples, resulting in $2229 \pm 350 \mathrm{Ma}, 2935 \pm 280 \mathrm{Ma}$, and $2661 \pm 60$ Ma errorchron ages, respectively. The $\mathrm{Pb}-\mathrm{Pb}$ regression ages in all rocks $(2661 \pm 60$ $\mathrm{Ma})$ and in the basalts and gabbro $(2725 \pm 25 \mathrm{Ma})$ are closer to the zircon U-Pb ages yielded by the porphyritic rhyolites (2722-2724 Ma) than those yielded by Sm-Nd and $\mathrm{Rb}-\mathrm{Sr}$ systems, suggesting that during metamorphism the U-Pb system was the least affected system among the three isotope systems. 


\subsection{Acknowledgements}

We want to show our gratitude to M. Price and J.C. for their help during the ICPMS experiment. This is a contribution of NSERC grant to A. Polat.

\subsection{References}

Anhaeusser, C.R., 2014. Archaean greenstone belts and associated granitic rocks-A review. Journal of African Earth Sciences 100, 684-732.

Anhaeusser, C.R., Robb, L.J., 1981. Magmatic cycles and crustal evolution of the Archaean granitic crust in the Eastern Transvaal and Swaziland. In: Glover, J.E., Groves, D.I. (Eds.), Archaean Geology, Second International Symposium, Perth 1980. Geological Society of Australia Special Publication 7, pp. 457-467.

Anhaeusser, C.R., Robb, L.J., 1983. Chemical analyses of granitoid rocks from the Barberton Mountain Land. In: Anhaeusser, C.R. (Ed.), Contributions to the Geology of the Barberton Mountain Land. Geological Society of South Africa Special Publication 9, pp. 131-151.

Ashwal, L., Morrison, D., Phinney, W., Wood, J., 1983. Origin of Archean anorthosites: evidence from the Bad Vermilion Lake anorthosite complex, Ontario. Contributions to Mineralogy and Petrology 82, 259-273. Ayer, J., Davis, D., 1997. Neoarchean evolution of differing convergent margin assemblages in the Wabigoon Subprovince: geochemical and geochronological evidence from the Lake of the Woods greenstone belt, Superior Province, Northwestern Ontario. Precambrian Research 81, 155-178.

Ayer, J.A. and Davis, D.W. 1997. Neoarchean evolution of differing convergent margin assemblages in the Wabigoon Subprovince: geochemical and 
geochronological evidence from the Lake of the Woods greenstone belt, Superior Province, northwestern Ontario. Precambrian Research 81, 155-178.

Ayer, J.A., Dostal, J., 2000. $\mathrm{Nd}$ and $\mathrm{Pb}$ isotopes from the Lake of the Woods greenstone belt, northwestern Ontario: implications for mantle evolution and the formation of crust in the southern Superior Province. Canadian Journal of Earth Sciences 37, 1677-1689.

Backeberg, N.R., Rowe, C.D., van Hinsberg, V.J., Bellefroid, E.J., 2014. Structural and metamorphic evidence for Mesoarchean subduction in the Finlayson Lake greenstone belt, Superior Province, Ontario. Precambrian Research 249, 100-114.

Barrett, T.J., MacLean, W.H., 1994. Chemostratigraphy and hydrothermal alteration in exploration for VHMS deposits in greenstones and younger volcanic rocks. In: Lentz, D.R. (Ed.). Alteration and Alteration Processes Associated with Oreforming Systems. Geological Association of Canada, Short Course Notes 11, pp. $433-467$.

Barrie, C.T., Ludden, J.N., and Green, T.H., 1993. Geochemistry of volcanic rocks associated with $\mathrm{Cu}-\mathrm{Zn}$ and $\mathrm{Ni}-\mathrm{Cu}$ deposits in the Abitibi subprovince. Economic Geology 88, 1341-1358.

Blackburn, C.E., John, G.W., Davis, D.W., 1991. Wabigoon Subprovince. In: Thurston, P.C., Williams, H.R., Sutcliffe, R.H., Stott, G.M. (Eds.), Geology of Ontario, Special vol. 4 (1). Ministry of Northern Development and Mines, Ontario Geological Survey, Sudbury, Ontario. Canada, pp. 303-381.

Card, K.D., Ciesielski, A., 1986. DNAG\#1: Subdivision of the Superior Province of the Canadian Shield. Geoscience Canada 13, 5-13.

Claeson, D.T., Meurer, W.P., 2004. Fractional crystallization of hydrous basaltic 'arctype' magmas and the formation of amphibole-bearing gabbroic cumulates. 
Contribution to Mineralogy and Petrology 147, 288-304.

Condie, K.C., Viljoen, M.J., Kable, E.J.D., 1977. Effects of alteration on element distributions in Archean tholeiites from the Barberton Greenstone Belt, South Africa. Contribution to Mineralogy and Petrology 64, 75-89.

Condie, K.C., 1981. Archaean greenstone belts. In: Windley, B.F. (Eds), Elsevier scientific publishing company, Amsterdam, Netherlands, pp. 1-44.

Condie, K.C., 1994. Greenstones through time. In: Condie, K.C. (Eds.), Archaean Crustal Evolution. Elsevier, Amsterdam, pp. 85-120.

Corfu, F. 1988. Differential response of $\mathrm{U}-\mathrm{Pb}$ systems in coexisting accessory minerals, Winnipeg River Subprovince, Canadian Shield: Implications for Archean growth and stabilization. Contributions to Mineralogy and Petrology 98, $312-325$.

Corfu, F., Davis, D.W., 1992. A U-Pb geochronological framework for the western Superior Province, Ontario. In: Geology of Ontario, Ontario Geological Survey, Special vol. 4, Part 2, pp. 1335-1346.

Davis, D.W., 1999. Report for the Ontario Geological Survey on the U-Pb geochronology of rocks from the Onaman Lake belt. Earth Science Department, Royal Ontario Museum, p.20.

Davis, D.W., Edwards, G.R., 1982. Zircon U-Pb ages from the Kakagi Lake area, Wabigoon Subprovince, northwest Ontario. Canadian Journal of Earth Sciences $19,1235-1245$.

Davis, D.W., Edwards, G.R., 1986. Crustal evolution of Archean rocks in the Kakagi Lake area, Wabigoon Subprovince, Ontario, as interpreted from high precision U-Pb geochronology. Canadian Journal of Earth Sciences 23, 182-192.

Davis, D.W., Jackson, M. 1988. Geochronology of the Lumby Lake greenstone belt: a 
3 Ga complex within the Wabigoon Subprovince, northwest Ontario. Geological Society of America Bulletin 100, 818-824.

Davis, D.W., Sutcliffe, R.H., and Trowell, N.F. 1988. Geochronological constraints on the tectonic evolution of a late Archean greenstone belt, Wabigoon subprovince, northwest Ontario. Precambrian Research 39, 171-191,

Davis, D.W., Poulsen, K., Kamo, S., 1989. New insights into Archean crustal development from geochronology in the Rainy Lake area, Superior Province, Canada. The Journal of Geology 97(4), 379-398.

Davis, D.W., and Smith, P.M. 1991. Archean gold mineralization in the Wabigoon Subprovince, a product of crustal accretion: evidence from $\mathrm{U}-\mathrm{Pb}$ geochronology in the Lake of the Woods area, Superior Province, Canada. The Journal of Geology 99, 337-353.

DePaolo, D.J., 1981. Neodymium isotope geochemistry: An introduction. New York, Springer-Verlag, pp. 187.

DePaolo, D.J., Wasserburg, G.J., 1976. Nd isotopic variations and petrogenetic models. Geophysical Research Letters 3, 249-252.

de Wit, M.J., Ashwal, L.D., 1997. Convergence towards divergent models of greenstone belts. In: de Wit, M.J., Ashwal, L.D. (Eds.), Greenstone Belts. Oxford University Press, Oxford, U.K., pp. ix-xvii.

de Wit, M.J., 1998. On Archaean granites, greenstones, cratons and tectonics: does the evidence demand a verdict? Precambrian Research 91, 181-226.

de Wit, M.J., 2004. Archean greenstone belts do contain fragments of ophiolites. In: Kusky, T.M. (Ed.), Precambrian Ophiolites and Related Rocks. Development in Precambrian Geology, vol. 13, pp. 599-614.

Deng, H.., Kusky, T., Polat, A., Wang L., Wang, J., Wang, S., 2013. Geochemistry of 
Neoarchean mafic volcanic rocks and late mafic dikes in the Zanhuang Complex, Central Orogenic Belt, North China Craton: Implications for geodynamic setting. Lithos 175-176, 193-212.

Devaney, J.R., Williams, H.R., 1989. Evolution of an Archean subprovince boundary: a sedimentological and structural study of part of the Wabigoon-Quetico boundary in northern Ontario Canadian Journal of Earth Sciences 26, 1013-1026.

Dilek, Y., Furnes, H., 2011. Ophiolite genesis and global tectonics: geochemical and tectonic fingerprinting of ancient oceanic lithosphere. Geological Society of America Bulletin 123, 387-411.

Dilek, Y., Furnes, H., 2014. Ophiolites and their origins. Elements 10, 93-100.

Dostal, J., Mueller, W.U., 2013. Deciphering an Archean mantle plume: Abitibi greenstone belt, Canada. Gondwana Research 23, 493-505.

Dostal, J., Mueller, W., Murphy, J., 2004. Archean molasse basin evolution and magmatism, Wabigoon Subprovince, Canada. The Journal of Geology 112, 435 454.

Dostal, J., Mueller, W.U., 2013. Deciphering an Archean mantle plume: Abitibi greenstone belt, Canada. Gondwana Research 23, 493-505.

Eggins, S.M., Woodhead, J.D., Kinsley, L.P.J., Mortimer, G.E., Sylvester, P., McCulloch, M.T., Hergt, J.M., Handler, M.R., 1997. A simple method for the precise determination of $\geq 40$ trace elements in geological samples by ICP-MS using enriched isotope internal standardization. Chemical Geology 134, 311-326.

Ewart, A., Bryant, W.B., 1972. Petrography and geochemistry of the igneous rocks from Eua Tongan Islands. Geological Society of America Bulletin 83, 3281-3298.

Ewart, A., Bryant, W.B., Gibb, J.B., 1973. Mineralogy and geochemistry of the younger volcanic islands of Tonga, southeast Pacific. Journal of Petrology 14, 
116-140.

Frei, R., Villa, I.M., Nägler, T.F., Kramers, J.D., Pryzbylowicz, W.J., Prozesky, V.M., Hofmann, B.A., Kamber, B.S., 1997. Single mineral dating by $\mathrm{Pb}-\mathrm{Pb}$ stepleaching method; assessing the mechanisms. Geochimica et Cosmochimica Acta $61,393-414$.

Frei, R., Polat, A., 2013. Chromium isotope fractionation during oxidative weathering -implications from the study of a Paleoproterozoic (ca. 1.9 Ga) paleosol, Schreiber Beach, Ontario, Canada. Precambrian Research 224, 434-453.

Furnes, H., de Wit, M.J., Robins, B., 2013. A review of new interpretations of the tectonostratigraphy, geochemistry and evolution of the Onverwacht Suite, Barberton Greenstone Belt, South Africa. Gondwana Research 23, 403-428.

Furnes, H., Dilek, Y., de Wit, M., 2015. Precambrian greenstone sequences represent different ophiolite types. Gondwana Research 27, 649-685.

Greene, A.R., Debari, S.M., Kelemen, P.B., Blusztajn, J., Clift, P.D., 2006. A detailed geochemical study of island arc crust: the Talkeetna arc section, south-central Alaska. Journal of Petrology 47 (6), 1051-1093.

Harris, F. R., 1974. Geology of the Rainy Lake area, District of Rainy Lake. Ontario Division 25 of Mines, GR 115. 94 p. Accompanied by Maps 2278 and 2279, scale: 1 in. to $112 \mathrm{mi}$.

Hart, R.J., Welke, H.J., Nicolaysen, L.O., 1981. Geochronology of the deep profile through Archean basement at Vredefort, with implications for early crustal evolution. Journal of Geophysical Research 86, 10663-10780.

Hart, S., Davis, G., 1969. Zircon U-Pb and whole-rock Rb-Sr ages and early crustal development near Rainy Lake, Ontario. Geological Society of America Bulletin $80,595-616$. 
Henry, P., Stevenson, R.K., Gariepy, C., 1998. Late Archaean mantle composition and crustal growth in the Western Superior Province of Canada: neodymium and lead isotopic evidence from the Wawa, Quetico and Wabigoon subprovinces. Geochimica et Cosmochimica Acta 62, 143-157.

Henry, P., Stevenson, R.K., Larbi, Y., Gariepy, C., 2000. Nd isotopic evidence for Early to Late Archaean (3.4-2.7 Ga) crustal growth in the Western Superior Province (Ontario, Canada). Tectonophysics 322, 135-151.

Hoffmann, A.W., 1988. Chemical differentiation of the Earth: the relationship between mantle, continental crust, and oceanic crust. Earth and Planetary Science 90(3), 297-314.

Hollings, P., Kerrich, R., 2004. Geochemical systematics of tholeiites from the 2.86 Ga Pickle Crow Assemblage, northwestern Ontario: arc basalts with positive and negative $\mathrm{Nb}$ and $\mathrm{Hf}$ anomalies. Precambrian Res. 134, 1-20.

Hollings, P., Kerrich, 2006. Light rare earth element depleted to enriched basaltic flows from 2.8 to $2.7 \mathrm{Ga}$ greenstone belts of the Uchi Subprovince, Ontario, Canada. Chem. Geol. 227, 133-153.

Hollings, P., Wyman, D.A., 1999. Trace element and Sm-Nd systematics of volcanic and intrusive rocks from the $3 \mathrm{Ga}$ Lumby Lake Greenstone Belt, Superior Province: evidence for Archean plume- arc interaction. Lithos 46, 189-213.

Hollings, P., Wyman, D., Kerrich, R., 1999. Komatiite-basalt-rhyolite volcanic association in Northern Superior Province greenstone belts: significance of plume-arc interaction in the generation of the proto continental Superior Province. Lithos 46, 137-161.

Horwitz, E.P., Chiarizia, R., Dietz, M.L., 1992. A novel strontium-selective extraction chromatographic resin. Solvent Extraction and Ion Exchange 10, 313-36. 
Hunter, D.R., Stowe, C.W., 1997. A historical review of the origin, composition, and setting of Archean greenstone belts (pre-1980). In: De Wit, M.J., Ashwal, L.D. (Eds.), Greenstone Belts, vol. 1. Clarendon Press, Oxford, pp. 5-29.

Irvine, T., Baragar, W., 1971. A guide to the chemical classification of the common volcanic rocks. Canadian Journal of Earth Sciences 8, 523-548.

Jenner, G.A., Longerich, H.P., Jackson, S.E., Fryer, B.J., 1990. ICP-MS; a powerful tool for high-precision trace-element analysis in earth sciences; evidence from analysis of selected U. S. G. S. Reference samples. Chemical Geology 83, 133 148.

Kerrich, R., Polat, A., 2006. Archaean greenstone-tonalite duality: thermochemical mantle convection models or plate tectonics in the early Earth global dynamics? Tectonophysics 415, 141-165.

Kerrich, R., Wyman, D., Hollings, P., Polat, A., 1999. Variability of Nb/U and Th/La in 3.0 to 2.7 Ga Superior Province ocean plateau basalts: implications for the timing of continental growth and lithosphere recycling. Earth and Planetary Science Letters 168, 101-115.

Kusky, T.M., 2004. Epilogue: What if anything have we learned about Precambrian ophiolites and early Earth processes? In: Kusky T.M. (Ed.), Precambrian Ophiolites and Related Rocks, Developments in Precambrian Geology, Vol. 13 (K.C. Condie, Series Editor), Elsevier B.V., Amsterdam, pp.727-637.

Kusky, T.M., Hudleston, P.J., 1999. Growth and demise of an Archaean carbonate platform, Steep Rock Lake, Ontario, Canada. Canadian Journal of Earth Sciences $36,565-584$. 
Kusky, T.M., Li, X., Wang, Z., Fu, J., Ze, L., Zhu, P., 2014. Are Wilson Cycles preserved in Archean cratons? A comparison of the North China and Slave cratons. Canadian Journal of Earth Sciences 51, 297-311.

Kusky, T. M., Polat, A., 1999. Growth of granite-greenstone terranes at convergent margins and stabilization of Archean cratons. Tectonophysics 305, 43-73.

Kwok, Y.Y., Amelin, Y., Kamo, S.L., Davis, D.W., 2000. Report for the Ontario Geological Survey on $\mathrm{U}-\mathrm{Pb}$ geochronology of rocks from the Onaman greenstone belt. Earth Science Department, Royal Ontario Museum, p. 37.

Lesher, C.M., Goodwin, A.M., Campbell, I.H., Gorton, M.P., 1986. Trace-element geochemistry of ore-associated and barren, felsic metavolcanic rocks in the Superior Province, Canada. Canadian Journal of Earth Sciences 23, 222-237.

Liu, Y. S., Hu, Z. C., Gao, S., Günther, D., Xu, J., Gao, C. G. and Chen, H. H., 2008a. In situ analysis of major and trace elements of anhydrous minerals by LA-ICPMS without applying an internal standard. Chemical Geology 257, 34-43.

Liu, Y. S., Zong, K. Q., Kelemen, P. B. and Gao, S., 2008b. Geochemistry and magmatic history of eclogites and ultramafic rocks from the Chinese continental scientific drill hole: Subduction and ultrahigh-pressure metamorphism of lower crustal cumulates. Chemical Geology 247, 133-153.

Liu, Y., Gao, S., Hu, Z., Gao, C., Zong, K. and Wang, D., 2010a. Continental and oceanic crust recycling-induced melt-peridotite interactions in the Trans-North China Orogen: U-Pb dating, $\mathrm{Hf}$ isotopes and trace elements in zircons of mantle xenoliths. Journal of Petrology 51, 537-571.

Liu, Y., Hu, Z., Zong, K., Gao, C., Gao, S., Xu, J. and Chen, H., 2010b. Reappraisement and refinement of zircon $\mathrm{U}-\mathrm{Pb}$ isotope and trace element analyses by LA-ICP-MS. Chinese Science Bulletin 55(15), 1535-1546. 
Lodge, R.W.D., Gibson, H.L., Stott, G.M., Hundak, G.J., Jirsa, M.A., Hamilton, M.A., 2013. New U-Pb geochronology from Timiskaming-type assemblages in the Shebandowan and Vermilion greenstone belts, Wawa subprovince, Superior Craton: Implications for the Neoarchean development of the southwestern Superior Province. Precambrian Research 235, 264-277.

Lodge, R.W.D., Gibson, H.L., Stott, G.M., Franklin, J.M., Hamilton, M.A., 2014. Geodynamic reconstruction of the VMS-hosting Winston Lake greenstone belt and VMS deposits: New trace element geochemistry and U-Pb geochronology. Economic Geology 109, 1291-1313.

Lodge, R.W.D., Gibson, H.L., Stott, G.M., Franklin, J.M., Hudak, G.J., 2015. Geodynamic setting, crustal architecture, and VMS metallogeny of ca. $2720 \mathrm{Ma}$ greenstone belt assemblages of the northern Wawa subprovince, Superior Province. Canadian Journal of Earth Sciences 52, 196-214.

Ludden, J., Gelienas, L., Trudel, P., 1982. Archean metavolcanics from the RouynNoranda district, Abitibi greenstone belt, Quebec; 2. Mobility of trace elements and petrogenetic constraints, Canadian Journal of Earth Science 19, 2276-2287.

Ludwig, K. R., 2003. ISOPLOT 3.00: A Geochronological Toolkit for Microsoft Excel. Berkeley: Berkeley Geochronology Center, California.

Musacchio, G., White, D.J., Asudeh, I., and Thomson, C.J. 2004. Lithospheric structure and composition of the Archean western Superior Province from seismic refraction/wide-angle reflection and gravity modeling. Journal of Geophysical Research 109(3), B03304. doi: 10.1029/2003JB002427.

Münker, C., 1998. Nb/Ta fractionation in a Cambrian arc/back arc system, New Zealand: source constraints and application of refined ICPMS techniques. Chemical Geology 144, 23-45. 
Murphy, J.B., 2007. Arc magmatism II: geochemical and isotopic characteristics. Geoscience Canada 34, 7-35.

Ontario Department of Mines, 1961. Aeromagnetic map of Seine Bay, Map 1150 G, Sheet 52, c/10.

Ordóñez-Calderón, J.C., Polat, A., Fryer, B.J., Gagnon, J.E., 2011.Field and geochemical characteristics of Mesoarchean to Neoarchean volcanic rocks in the Storø greenstone belt, SW Greenland: Evidence for accretion of intra-oceanic volcanic arcs. Precambrian Research 184, 24-42.

Pearce, J.A., 2008. Geochemical fingerprinting of oceanic basalts with applications to ophiolite classification and the search for Archean oceanic crust, Lithos 100, 1448.

Pearce, J.A., Harris, N.B., Tindle, A.G., 1984. Trace element discrimination diagrams for the tectonic interpretation of granitic rocks. Journal of petrology 25, 956-983.

Pearce, J.A., Peate, D.W., 1995. Tectonic implications of the composition of volcanic arc magmas. Annual Reviews of Earth and Planetary Sciences 23: 251-285.

Percival, J.A., 1989. A regional perspective of the Quetico metasedimentary belt, Superior Province, Canada. Canadian Journal of Earth Science 26, 677-693.

Percival, J.A., Williams, H.R., 1989. Late Quetico accretionary complex, Superior province, Canada. Geology 17, 23-25.

Percival, J.A., McNicoll, V., Brown, J.L., and Whalen, J.B. 2004. Convergent margin tectonics, central Wabigoon subprovince, Superior Province, Canada. Precambrian Research, 132: 213-244.

Percival, J.A., Sanborn-Barrie, M., Skulski T., Stott G.M., Helmstaedt H., White D.J., 2006a. Tectonic evolution of the western Superior Province from NATMAP and Lithoprobe studies. Canadian Journal of Earth Sciences 43, 1085-1117. 
Percival, J.A., McNicoll, V., Bailes, A.H., 2006b. Strike-slip juxtaposition of ca 2.72Ga juvenile arc and $>2.98 \mathrm{Ga}$ continental margin sequences and its implications for Archean terrane accretion, western Superior Province, Canada. Canadian Journal of Earth Science 43, 895-927.

Percival, J.A., Skulski, T., Sanborn-Barrie, M., Stott, G.M., Leclair, A.D., Corkery, M.T. and Boily, M., 2012. Geology and tectonic evolution of the Superior Province, Canada. In Tectonic Styles in Canada: The Lithoprobe Perspective Edited by J.A. Percival, F.A. Cook and R.M. Clowes. Geological Association of Canada Special Paper 49, pp. 321-378.

Percival, J.A., Stern, R.A., Skulski, T., Card, K.D., Mortensen, J.K., Begin, N.J., 1994. Minto block, Superior Province: Missing link in deciphering assembly of the Craton at 2.7 Ga. Geology 22, 43-73.

Polat, A., 2009. The geochemistry of Neoarchean (ca. 2700Ma) tholeiitic basalts, transitional to alkaline basalts, and gabbros, Wawa Subprovince, Canada: Implications for petrogenetic and geodynamic processes. Precambrian Research $168,83-105$

Polat, A., Hofmann, A.W., 2003. Alteration and geochemical patterns in the 3.7-3.8 Ga Isua greenstone belt, West Greenland. Precambrian Research 126, 197-218.

Polat, A., Appel, P.W.U., Fryer, B.J., 2011. An overview of the geochemistry of Eoarchean to Mesoarchean ultramafic to mafic volcanic rocks, SW Greenland: implications for mantle depletion and petrogenetic processes at subduction zones in the early Earth. Gondwana Research 20, 255-283.

Polat, A., Appel, P.W.U., Frei, R., Pan, Y., Dilek, Y., Ordonez-Caldeeron, J.C., Fryer, B., Raith, J.G., 2007. Field and geochemical characteristics of the Mesoarchean ( 3075 Ma) Ivisaartoq greenstone belt, southern West Greenland: Evidence for 
seafloor hydrothermal alteration in a supra-subduction oceanic crust. Gondwana Research 11, 69-91.

Polat, A., Hofmann, A.W., Münker, C., Regelous, M., and Appel, P.W.U, 2003. Contrasting geochemical patterns in the 3.7-3.8 Ga pillow basalt cores and rims, Isua greenstone belt, Southwest Greenland: Implications for post-magmatic alteration processes. Geochimica Cosmochimica Acta 67, 441-457.

Polat, A., Hofmann, A.W., Rosing, M., 2002. Boninite-like volcanic rocks in the 3.7 3.8 Ga Isua greenstone belt, West Greenland: Geochemical evidence for intraoceanic subduction zone processes in the early Earth. Chemical Geology 184, 231-254.

Polat, A., Kerrich, R., 2001b. Geodynamic processes, continental growth, and mantle evolution recorded in late Archean greenstone belts of the southern Superior Province, Canada. Precambrian Research 112, 5-25.

Polat, A., Kerrich, R., 2001a. Magnesian andesites, Nb-enriched basalt-andesites, and adakites from late Archean 2.7 Ga Wawa greenstone belts, Superior Province, Canada: implications for late Archean subduction zone petrogenetic processes. Contribution to Mineralogy and Petrology 141, 36- 52.

Polat, A., Kusky, T., Li, J., Fryer, B., Kerrich, R., Patrick, K., 2005. Geochemistry of Neoarchean (ca 2.55-2.50 Ga) volcanic and ophiolitic rocks of the Wutaishan belt, central orogenic belt, North China craton: implications for geodynamic setting and continental growth. Geological Society of America Bulletin117, $1387-1399$.

Polat, A., Wang, L., Appel, P.W.U., 2015. A review of structural patterns and melting processes in the Archean craton of West Greenland: Evidence for crustal growth at convergent plate margins as opposed to non-uniformitarian models. 
Tectonophysics, doi: 10.1016/j.tecto.2015.04.006

Poulsen, K.H., Borradaile, G.J., Kehlenbeck, M.M., 1980. An inverted Archean succession at Rainy Lake, Ontario. Canadian Journal of Earth Sciences 17, 13581369.

Rittman, A., 1957. On the Serial character of igneous rocks. Egyptian Journal of Geology 1, 23-48.

Rollinson, H., Claire Reid, C., Windley, B.F., 2010. Chromitites from the Fiskenæsset anorthositic complex, West Greenland: clues to late Archaean mantle processes. In: Kusky, T.M., Zhai, M.-G., Xiao, W. (Eds.), The Evolving Continents: Understanding Processes of Continental Growth. Geological Society, London, Special Publications, 338, pp. 197-212.

Rubin, J.N., Henry, C.D., Price, J.G., 1993. The mobility of zirconium and other "immobile" elements during hydrothermal alteration. Chemical Geology 110, $29-47$.

Sanborn-Barrie, M. and Skulski, T. 2006. Sedimentary and structural evidence for 2.7 Ga continental arc-oceanic arc collision in the Savant - Sturgeon greenstone belt, western Superior Province, Canada. Canadian Journal of Earth Sciences 43, 9951030.

Shirey, S.B., Hanson, G.N., 1986. Mantle heterogeneity and crustal recycling in Archean greenstone belts; evidence from $\mathrm{Nd}$ isotopes and trace elements in the Rainy Lake area, Superior Province, Ontario, Canada. Geochimica et Cosmochimica Acta 50, 2631-2651.

Şengör, A.M.C. 1990. Plate Tectonics and orogenic research after 25 years: A Tethyan perspective. Earth Science Reviews 27, 1-201.

Şengör, A.M.C., Natal'in, B. A., 2004. Phanerozoic analogues of Archaean oceanic 
basement fragments: Altaid ophiolites and ophirags. In: Kusky T.M. (Ed.), Precambrian Ophiolites and Related Rocks, Developments in Precambrian Geology, Vol. 13 (K.C. Condie, Series Editor), Elsevier B.V., Amsterdam, pp. $675-726$.

Stott, G.M, 1997. The Superior Province, Canada. In: de Wit, M.J., Ashwal, L.D. (Eds.), Greenstone Belts. Oxford University Press, Oxford, U.K., pp. 480-507.

Stott, G., M, Davis, D., W., 1999. Contributions to the tectonostratigraphic analysis of the Onaman-Tashota greenstone belt, eastern Wabigoon Subprovince. In: Harrap, R.M., Helmstaedt, H.H. (Eds.), Western Superior Lithoprobe Transect 5th Annual Workshop, 1-3 February 1999, Ottawa. Lithoprobe Secretariat, University of British Columbia, Lithoprobe Rep 70, pp 122-124.

Sproule, R.A., Lesher, C.M., Ayer, J.A., Thurston, P.C., Herzberg, C., 2002. Spatial and temporal variations in the geochemistry of komatiies and komatiitic basalts in the Abitibi greenstone belt. Precambrian Research 115, 153-186.

Stevenson, R.K., 1995. Crust and mantle evolution in the late Archean: Evidence from s Sm-Nd isotope study of the North Spirit lake greenstone belt, Northwestern Ontario, Canada. Geological Society of America Bulletin 107, $1458-1467$.

Sun, S.S., McDonough, W.F., 1989. Chemical and isotopic systematics of oceanic basalts: implications for mantle composition and processes. In: Saunders, A.D., Norry, M.J. (Eds.), Magmatism in the Ocean Basins: Geological Society, London, Special Publications, 42, pp. 313-345.

Sutcliffe, R.H., Barrie, C.T., Burrows, D., Beakhouse, G., 1993. Plutonism in the southern Abitibi Subprovince; a tectonic and petrogenetic framework. Economic Geology 88, 1359-1375. 
Sylvester, P.J., 1994. Archean granite plutons. In: Condie, K.C., (Ed.). Archean crustal evolution. Elsevier, Amsterdam, pp. 261-314.

Sylvester, P.J., Harper, G.D., Byerly, R.G., Thurston, P.C., 1997. Volcanic aspects. In:

De Wit, M., Ashwal, L. (Eds.), Tectonic Evolution of Greenstone belts. Oxford University Press, pp. 55-90.

Szilas, K., Næraa, T., Scherstén, A., Stendal, H., Frei, R., van Hinsberg, V. J., Kokfelt, T.F., Rosing, M. T. 2012. Origin of Mesoarchaean arc-related rocks with boninite/komatiite affinities from southern West Greenland. Lithos 144, 24-39.

Szilas, K., Van Hinsberg, V.J., Kisters, A.F.M., Hoffmann, J.E., Windley, B.F., Kokfelt, T.F., Scherstén, A., Frei, R., Rosing, M.T., Münker, C., 2013. Remnants of arcrelated Mesoarchean oceanic crust in the Tartoq Group of SW Greenland. Gondwana Research 23, 436-451.

Taylor, S.R., McLennan, S.M., 1985. The Continental Crust: Its Composition and Evolution. Blackwell, Oxford, pp. 312.

Thurston, P.C., Osmani, I.A., Stone, D., 1991. Northwestern Superior Province: review and tectonic analysis. In: Thurston, P.C., Williams, H.R., Sutcliffe, Stott, G.M. (Eds.), Geology of Ontario. Ontario Geological Survey, Special Publications, 4(1), pp. 81-141.

Tomlinson, K.Y., Hughes, D.J., Thurston, P.C., Hall, R.P., 1999. Plume magmatism and crustal growth at 2.9 to $3.0 \mathrm{Ga}$ in the Steep Rock and Lumby Lake area, Western Superior Province. Lithos 46, 103-136.

Tomlinson, K.Y., Davis, D.W., Percival, J.A., Hughes, D.J., Thurston, P.C., 2002. Mafic to felsic magmatism and crustal recycling in the Obonga Lake greenstone belt, western Superior Province: evidence from geochemistry, $\mathrm{Nd}$ isotopes and U-Pb geochronology. Precambrian Research 14, 295-325. 
Tomlinson, K.Y., Davis, D.W., Stone, D., Hart, T.R., 2003. U-Pb age and Nd isotopic evidence for Archean terrane development and crustal recycling in the southcentral Wabigoon subprovince, Canada. Contributions to Mineralogy and Petrology 144, 684-702.

Todt, W., Cliff, R.A., Hanser, A., Hofmann, A.W., 1993. Re-calibration of NBS lead standards using $202 \mathrm{~Pb}+205 \mathrm{~Pb}$ double spike. Terra Abstract 5, 396 .

Ujike, O., Goodwin, A.M., Shibata, T., 2007. Geochemistry and origin of Archean volcanic rocks from the Upper Keewatin assemblage (ca $2.7 \mathrm{Ga}$ ), Lake of the Woods Greenstone Belt, Western Wabigoon Subprovince, Superior Province, Canada. Island Arc 16, 191-208.

van Westrenen, W., Blundy, J.D., Wood, B.J., 2001. High field strength element/rare earth element fractionation during partial melting in the presence of garnet: implications for identification of mantle heterogeneities. Geochemistry, Geophysics, Geosystems 2 (Paper number 2000GC000133).

Vervoort, J.D., White, W.M., Thorpe, R.I., 1994. Neodymium and lead isotope ratios of the Abitibi greenstone belt: New evidence for early differentiation of the Earth. Earth and Planetary Science Letters 128, 215-229.

Whalen, J.B., Percival, J.A., McNicoll, V.J., Longstaffe, F.J., 2002. A mainly crustal origin for tonalitic granitoid rocks, Superior Province, Canada: Implications for late Archean tectonomagmatic processes, Journal of Petrology 43(8), 1551-1570.

Whalen, J.B., Percival, J.A., McNicoll, V.J., Longstaffe, F.J., 2004. Geochemical and isotopic $(\mathrm{Nd}-\mathrm{O})$ evidence bearing on the origin of late- to post-orogenic high-K granitoid rocks in the Western Superior Province: implications for late Archean tectonomagmatic processes. Precambrian Research 132, 303-326.

Williams, H.R., 1990. Subprovince accretion tectonics in the south-central Superior 
Province. Canadian Journal of Earth Sciences 27, 570-581.

White, D.J., Musacchio, G., Helmstaedt, H.H., Harrap, R.M., Thurston, P.C., van der Velden, A., and Hall, K. 2003. Images of a lower-crustal oceanic slab: Direct evidence for tectonic accretion in the Archean western Superior province. Geology 31, 997-1000.

Wiedenbeck, M., Allen, P., Corfu, F., Griffin, W. L., Meier, M., Oberli, F., Quadt, A. V., Roddick, J. C. Spiegel, W., 1995. Three natural zircon standards for U-Th-Pb, Lu-Hf, trace element and REE analyses. Geostandards and Geoanalytical Research 19, 1-23.

Winchester, J., Floyd, P., 1977. Geochemical discrimination of different magma series and their differentiation products using immobile elements. Chemical geology 20, $325-343$.

Winkler, H.G.F., 1974. Petrogenesis of metamorphic rocks. Springer-Verlag, New York, p. 334.

Wood, J., 1980. Epiclastic sedimentation and stratigraphy in the North Spirit Lake and Rainy Lake areas: a comparison. Precambrian Research, 12: 227-255.

Wood, J., Dekker, J., Jansen, J.G., Keay, J.P., Panagapko, D., 1980. Mine Center Area, District of Rainy River. Ontario Geological Survey, Preliminary Maps P2201 and P2202; Geological series, Scale, 1:15, 840.

Wyman, D., Ayer, J., Devaney, J., 2000. Niobium-enriched basalts from the Wabigoon subprovince, Canada: evidence for adakitic metasomatism above an Archean subduction zone. Earth and Planetary Science Letters 179, 21-30.

Xie, Q., Kerrich, R., Fan, J., 1993. HFSE/REE fractionations recorded in three komatiite-basalt sequences, Archean Abitibi greenstone belt: implications for multiple plume sources and depths. Geochimica et Cosmochimica Acta 57, 4111- 
4118.

Zaleski, E., van Breemen, O., and Peterson, V.L. 1999. Geological evolution of the Manitouwadge greenstone belt and Wawa-Quetico subprovince boundary, Superior Province, Ontario, constrained by $\mathrm{U}-\mathrm{Pb}$ zircon dates of supracrustal and plutonic rocks. Canadian Journal of Earth Sciences, 36: 945-966.

Zhou, S., Polat, A., Longstaffe, F.J., Yang, K., Fryer, B.J., Weisener, C., Formation of the Neoarchean Bad Vermilion Lake Anorthosite Complex and spatially associated granites at a Convergent Plate Margin, Superior Province, Western Ontario, Canada. Gondwana Research (in press). 

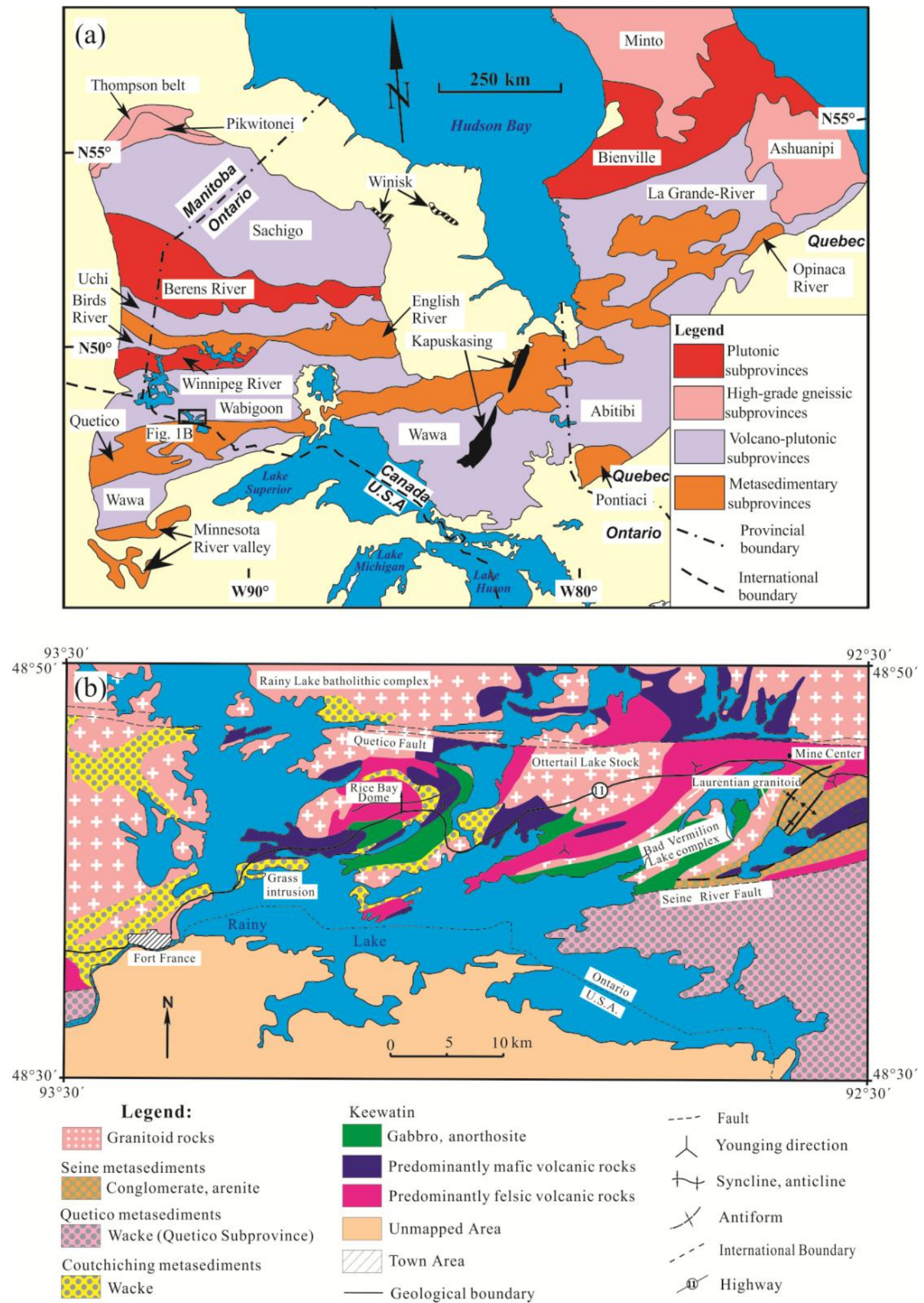

Figure 2.1. (a) Simplified tectonic map of the Superior Province (modified from Card and Ciesielski, 1986). (b) Regional geological map of the Rainy Lake area, Wabigoon subprovince, showing the location of the BVL greenstone belt and spatially related Ottertail Lake Stock and Bad Vermillion Lake anorthosite complex (modified from Blackburn et al., 1991). 

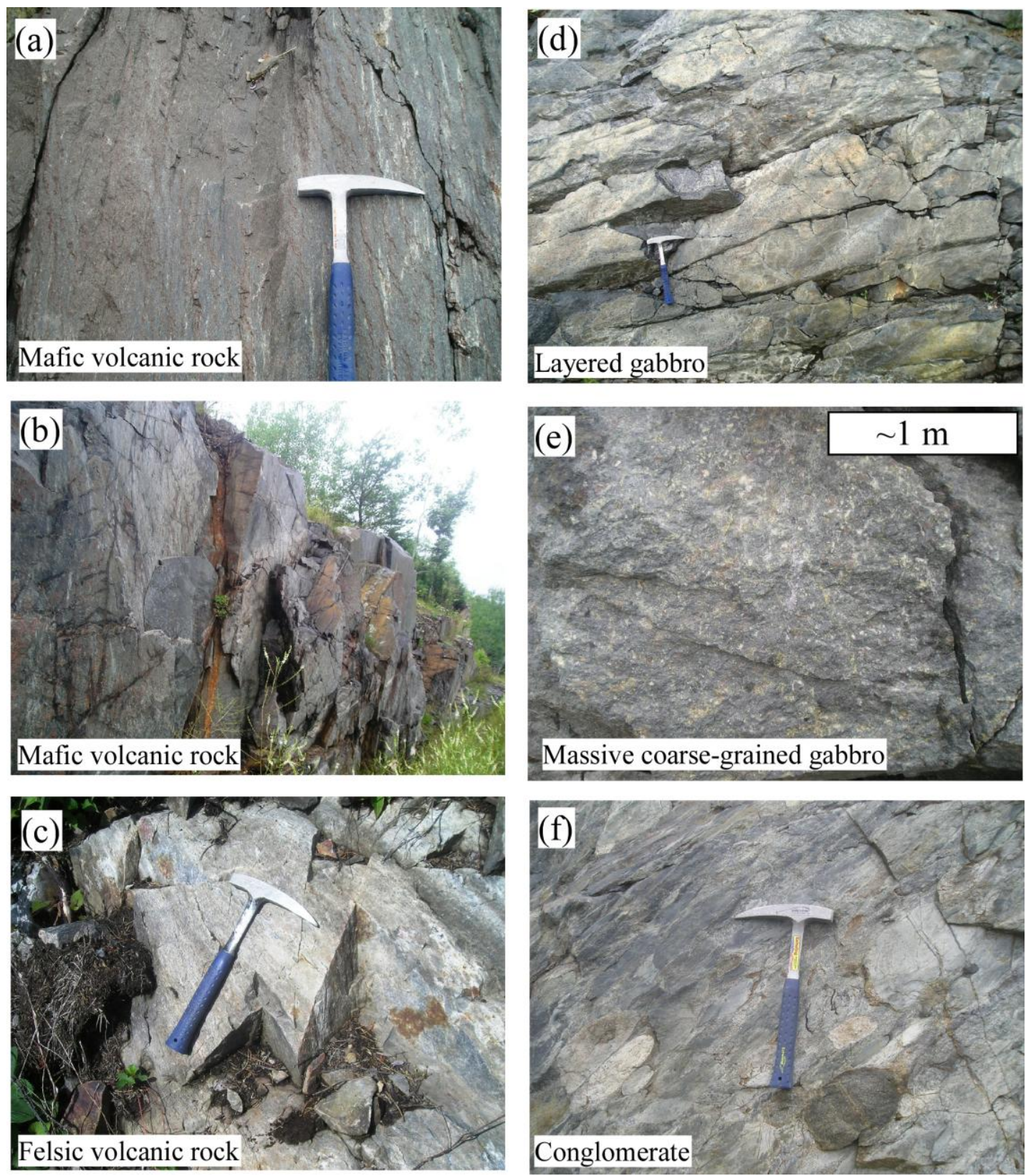

Figure 2.2. Field photographs illustrating the lithological characteristics and field relationships of the Bad Vermilion Lake greenstone belt. (a) Foliated and folded mafic volcanic rock (basalt). (b) Foliated and folded mafic volcanic rock (basalt). (c) Felsic volcanic rock (rhyolite). (d) Layered gabbro. (e) Massive gabbro. (f) Polymictic conglomerate, consisting of greenstone, gabbro, and gneiss boulders. 

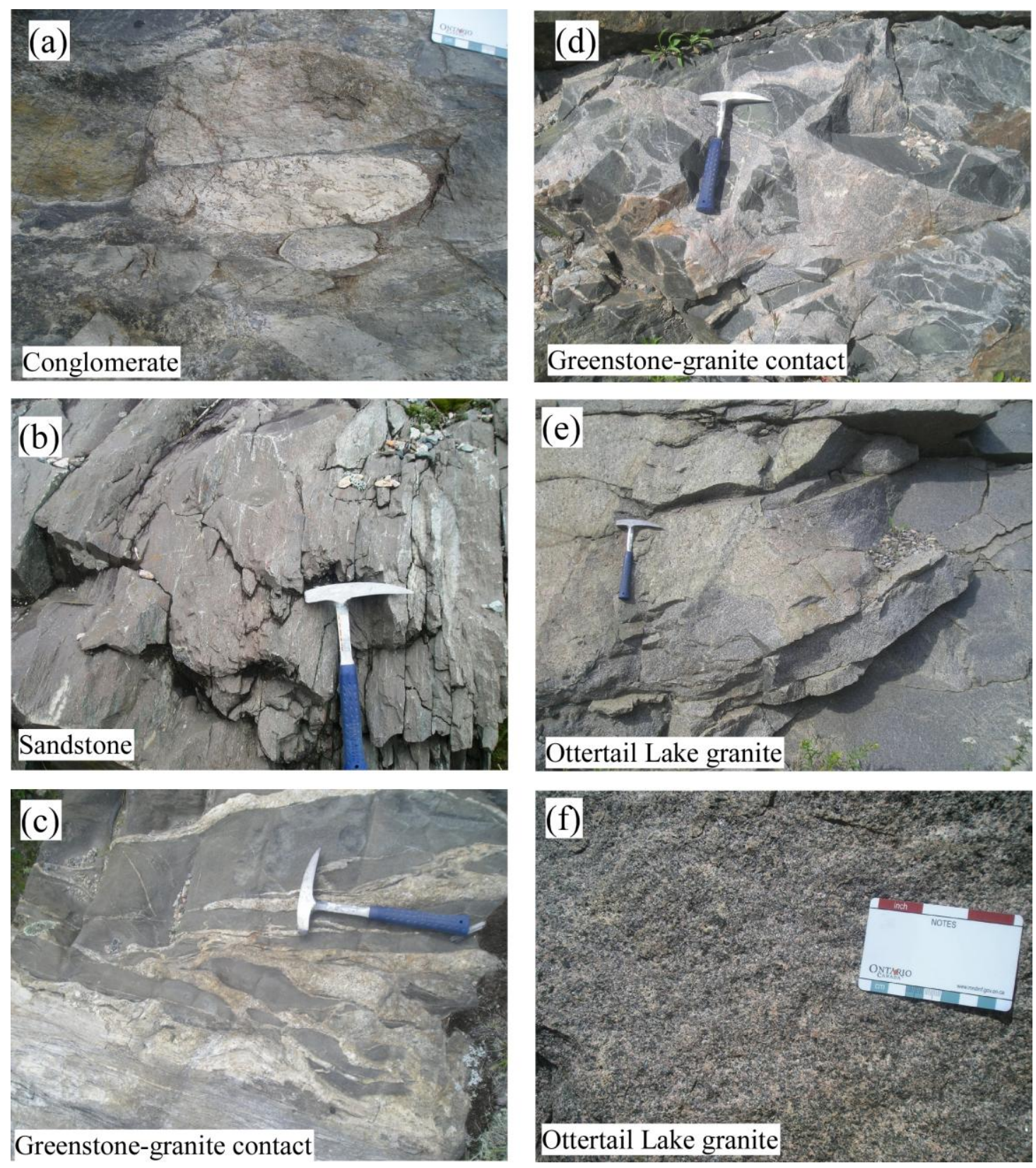

Figure 2.3. Field photographs illustrating the lithological characteristics and field relationships of the Seine Group (Timiskaming-type) and Ottertail Lake granite. (a) Polymictic conglomerate, consisting of greenstone, pyroclastic, gabbro, and gneiss boulders. (b) Foliated and folded sandstone (greywacke). (c) Intrusive contact between the BVL greenstone belt and the Ottertail Lake granite. (d) Intrusive contact between the BVL greenstone belt and the Ottertail Lake granite. (e) Ottertail Lake granite. (f) Ottertail Lake granite. 

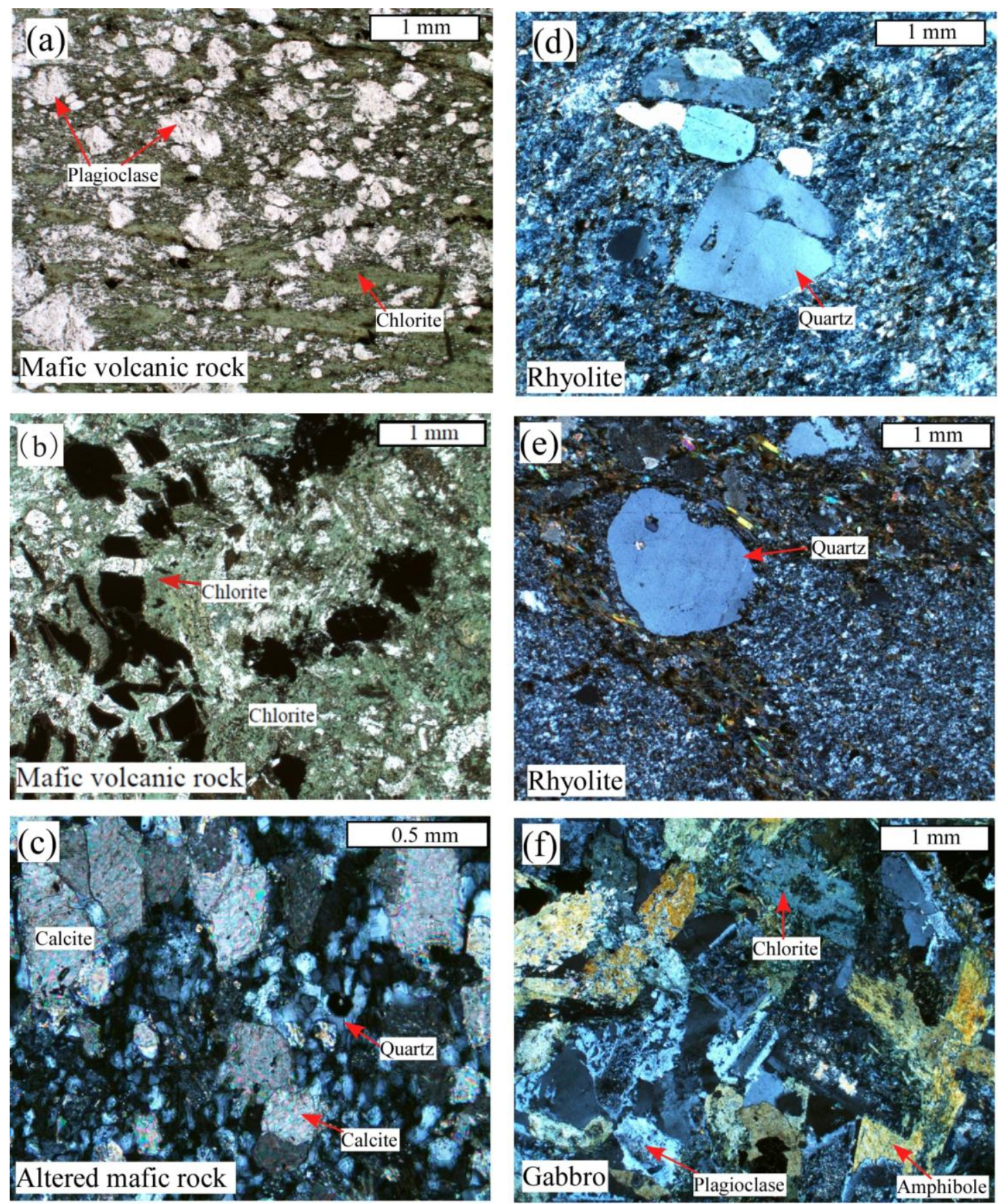

Figure 2.4. Photomicrographs illustrating the petrographic characteristics of the BVL greenstone belt. (a) Mafic volcanic rock (basalt) consisting mainly of plagioclase and chlorite, and minor quartz. (b) Mafic volcanic rock (basalt) consisting mainly of plagioclase, chlorite, and opaque mineral. (c) Altered mafic volcanic rock consisting mainly of calcite and quartz. (d) Felsic volcanic rock (rhyolite) including quartz phenocrysts. (e) Felsic volcanic rock (rhyolite) including quartz phenocrysts. (f) Gabbro characterized by altered plagioclase, chlorite, and amphibole. 

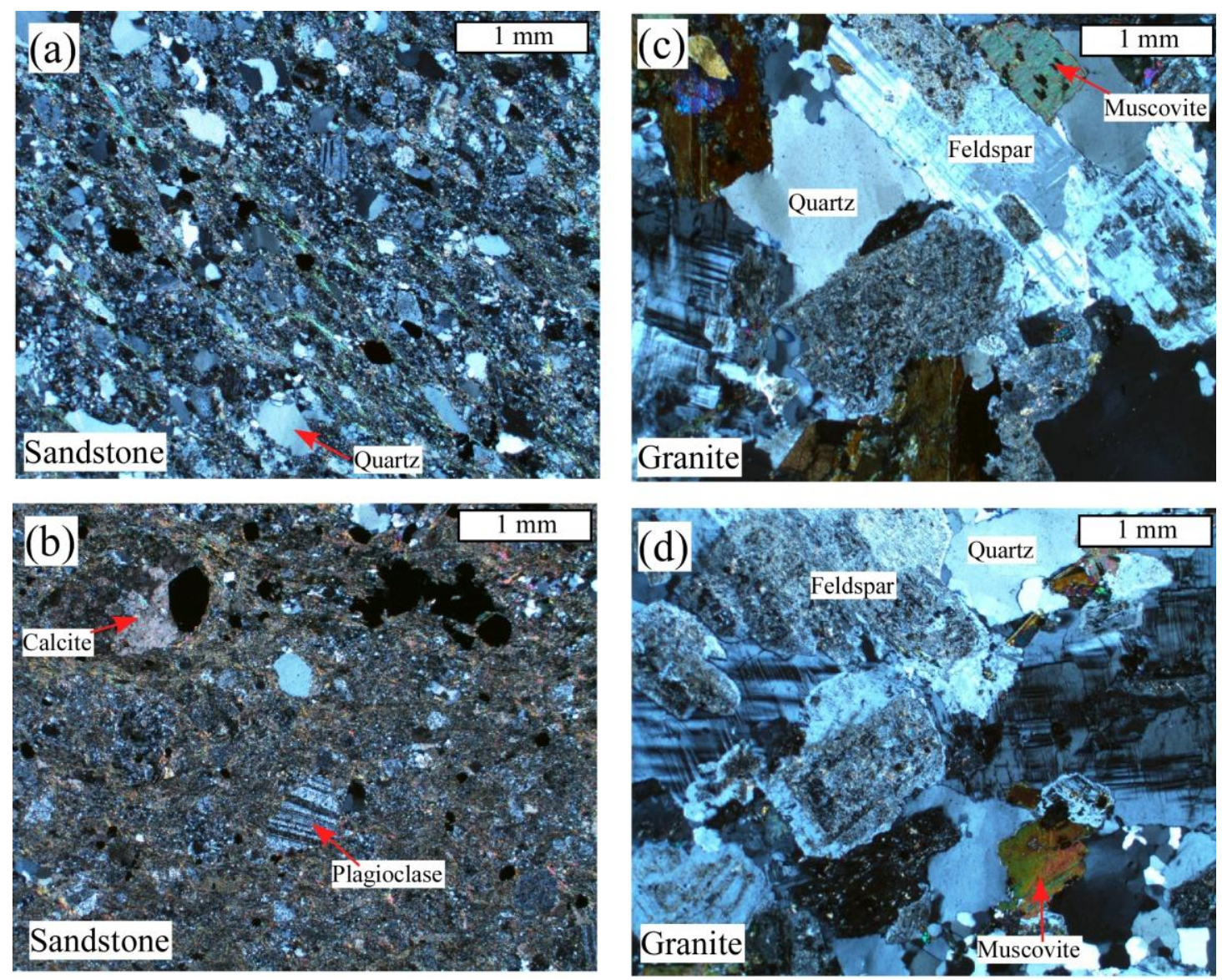

Figure 2.5. Photomicrographs illustrating the petrographic characteristics of the BVL greenstone belt. (a) Seine Group sandstone dominated by quartz. (b) Seine Group sandstone consisting mainly of plagioclase, calcite and opaque minerals. (c) Ottertail Lake granite consisting mainly of muscovite, quartz and feldspar. (d) Ottertail Lake granite characterized by muscovite, feldspar and quartz. 

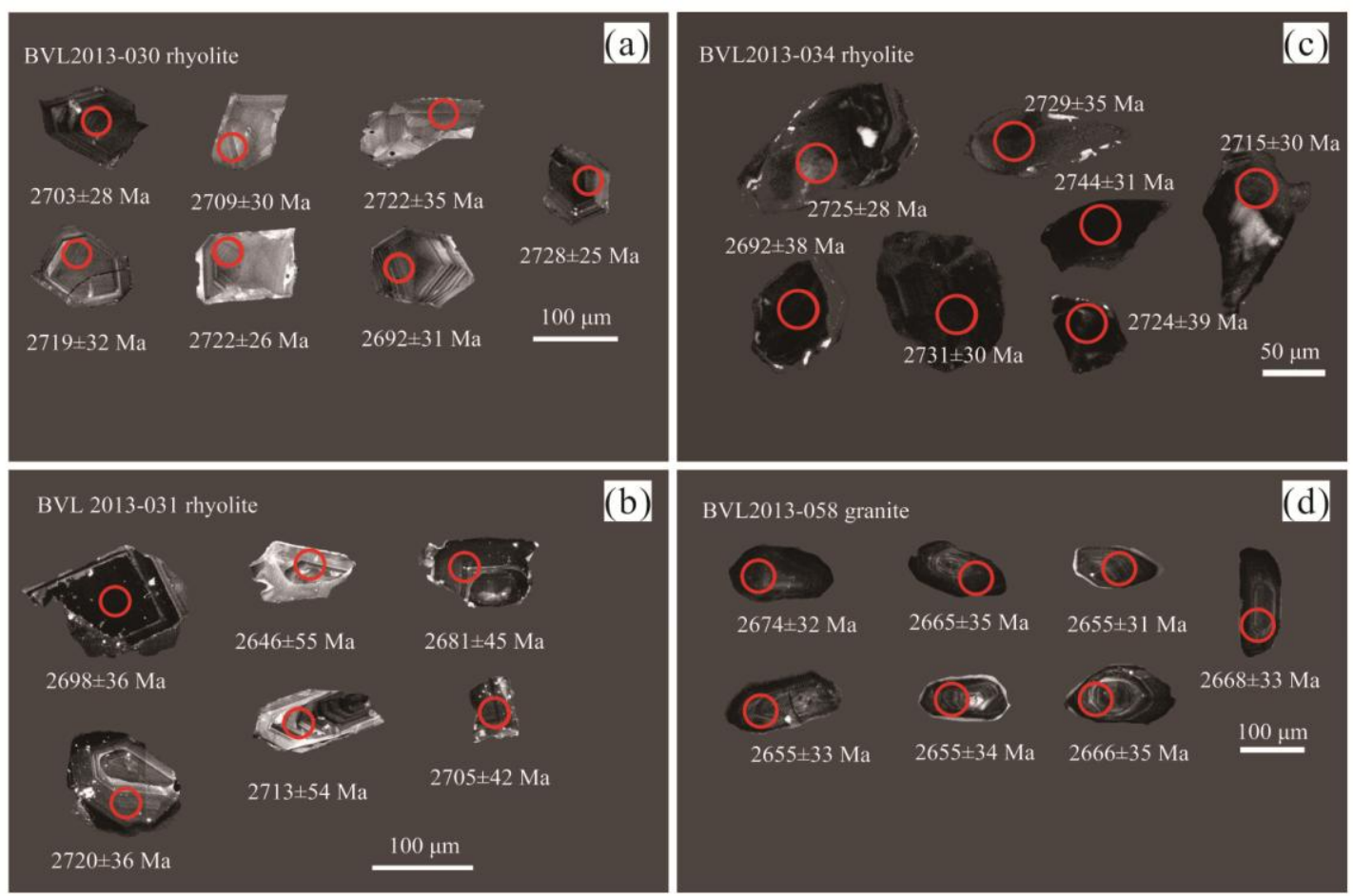

Figure 2.6. Cathodoluminescence images over representative zircons from the rhyolite samples (i.e., (a) BVL2013-030, (b) BVL2013-031, (c) BVL2013-034 in the Keewatin sequence, as well as (d) the granite sample BVL2013-058 in the Ottertail Lake Stock. Ellipse and circles with adjacent number denote spot positions, spot number and $207 \mathrm{~Pb} / 206 \mathrm{~Pb}$ ages. 

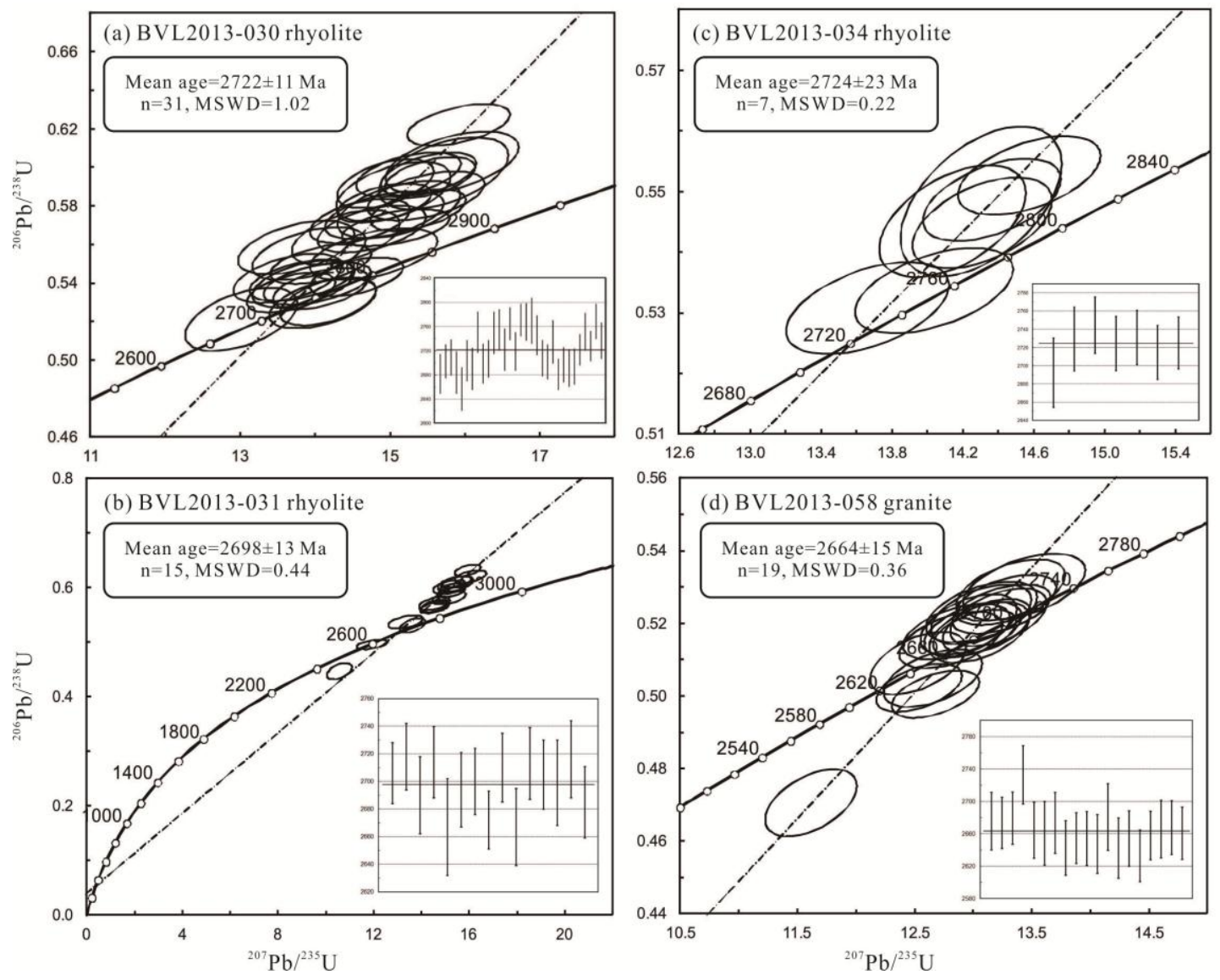

Figure 2.7. $\mathrm{U}-\mathrm{Pb}$ Concordia diagrams for the analyzed zircons illustrating the ages of the samples BVL2013-030, BVL2013-031, BVL2013-034 in the BVL greenstone belt, and the Ottertail Lake granite sample BVL2013-058. 

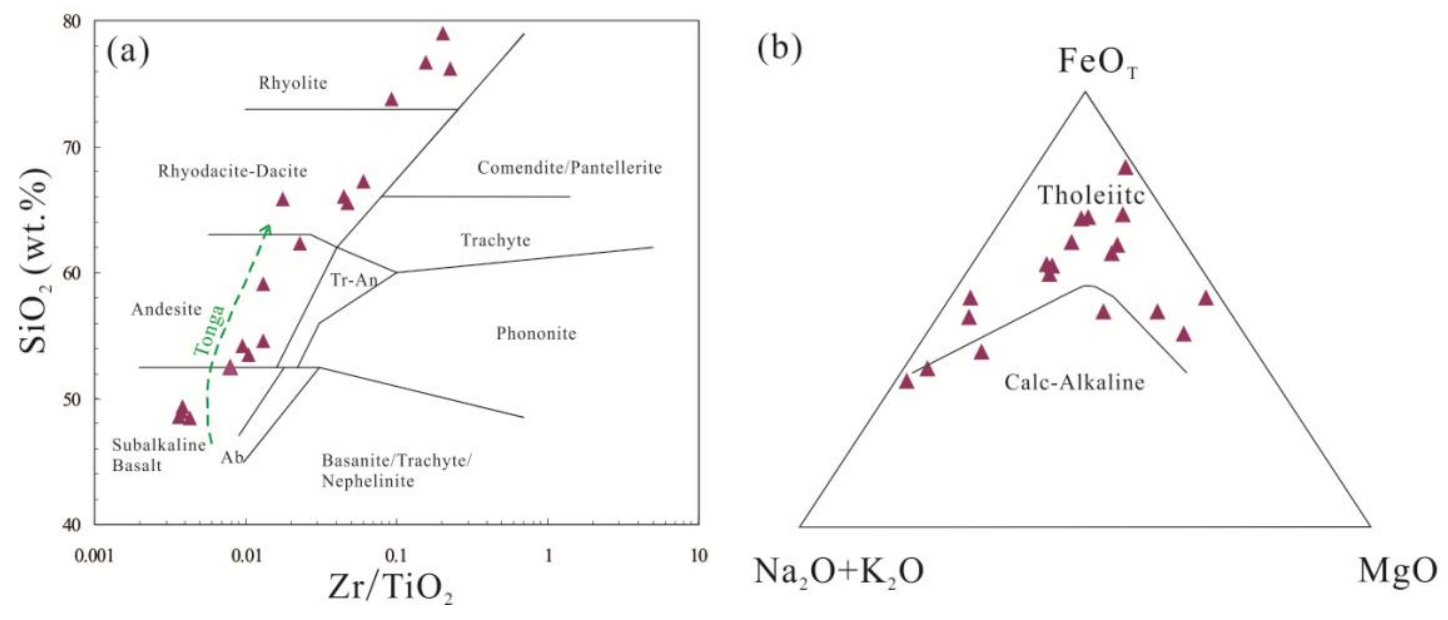

Figure 2.8. (a) $\mathrm{Zr} / \mathrm{TiO}_{2}$ versus $\mathrm{SiO}_{2}$ (after Winchester and Floyd, 1977) and (b) $\mathrm{FeO}_{\mathrm{T}^{-}}$ total alkalis $\left(\mathrm{Na}_{2} \mathrm{O}+\mathrm{K}_{2} \mathrm{O}\right)-\mathrm{MgO}$ diagram (after Irvine and Baragar, 1971) chemical classification diagram for volcanic rocks from the BVL greenstone belt. In the diagram, 'TrAn' denotes Trachyte-Andesite; 'Ab' denotes Alkaline-Basalt; 'Tonga' represents the relative distribution of volcanic products from Tonga trench, a typical intra-oceanic arc setting. 

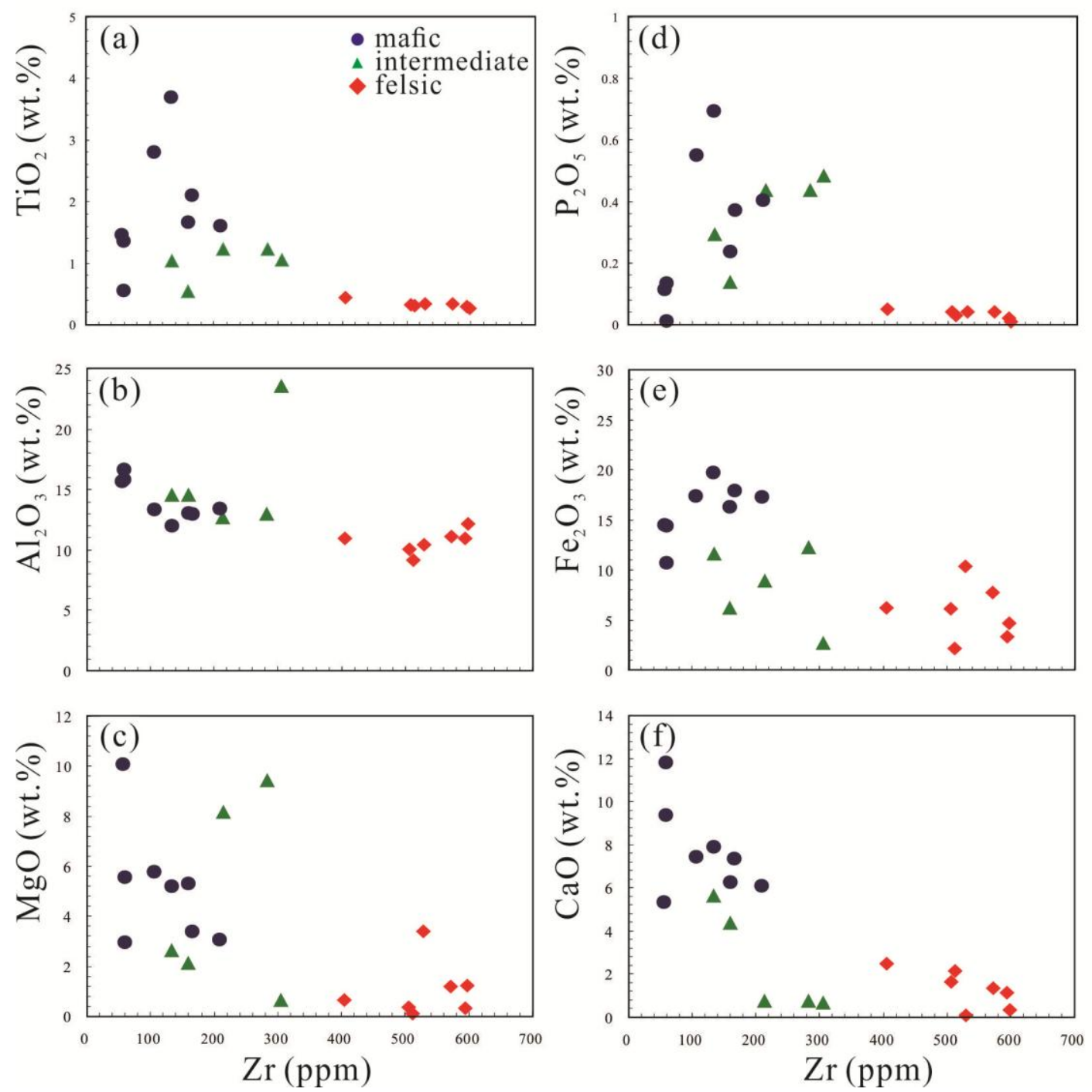

Figure 2.9. (a-f) Variation diagrams of $\mathrm{Zr}$ versus $\mathrm{TiO}_{2}$ (wt.\%), $\mathrm{Al}_{2} \mathrm{O}_{3}$ (wt.\%), $\mathrm{MgO}$ (wt.\%), $\mathrm{P}_{2} \mathrm{O}_{5}$ (wt.\%), $\mathrm{Fe}_{2} \mathrm{O}_{3}$ (wt.\%), and $\mathrm{CaO}$ (wt.\%), for mafic to felsic volcanic and volcaniclastic rocks in the BVL greenstone belt. 

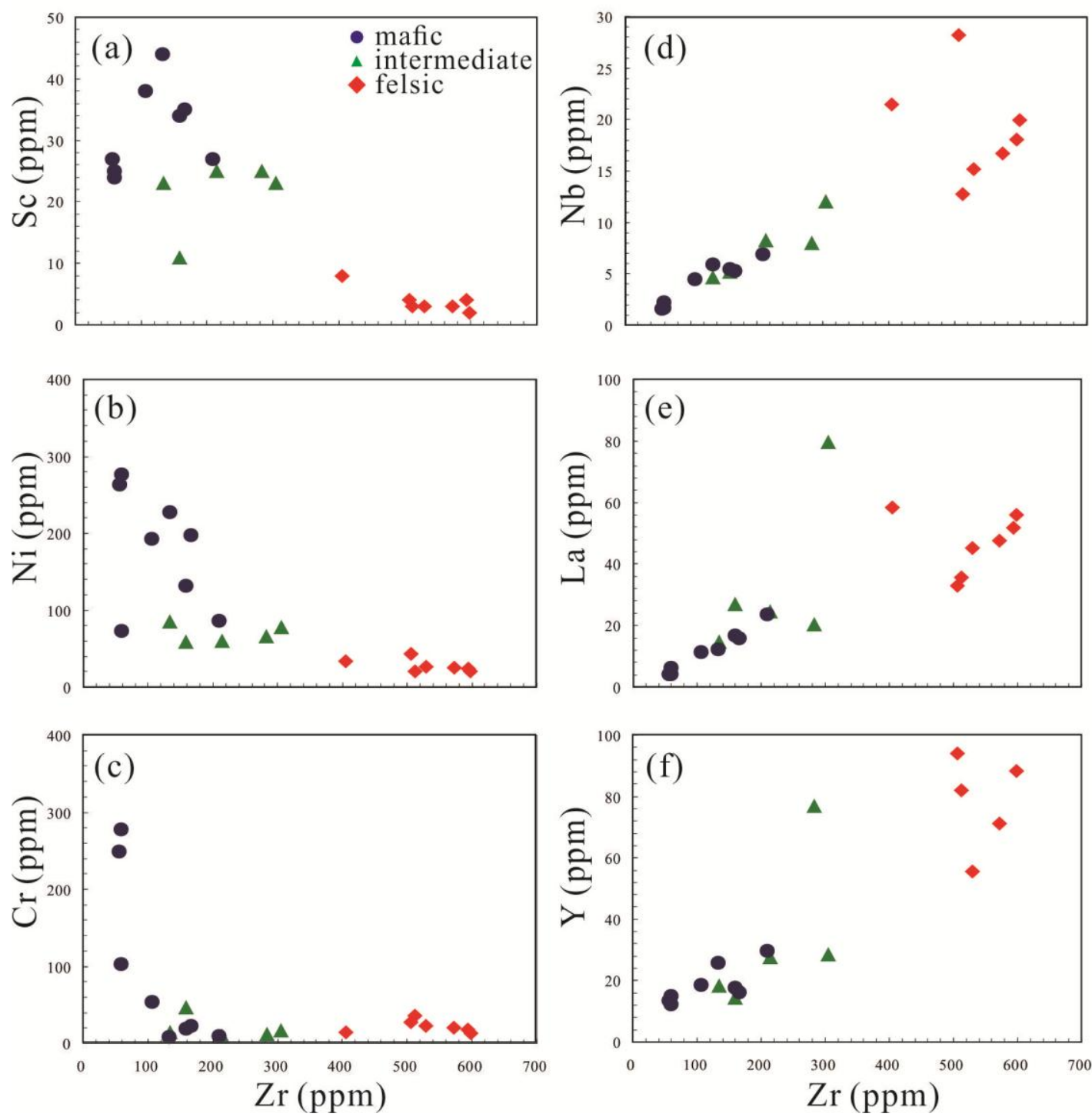

Figure 2.10. Variation diagrams of $\mathrm{Zr}$ versus $\mathrm{Nb}(\mathrm{ppm}), \mathrm{Ni}$ (ppm), La (ppm), Sc (ppm), Cr (ppm), and Y (ppm) for mafic to felsic volcanic and volcaniclastic rocks in the BVL greenstone belt. 

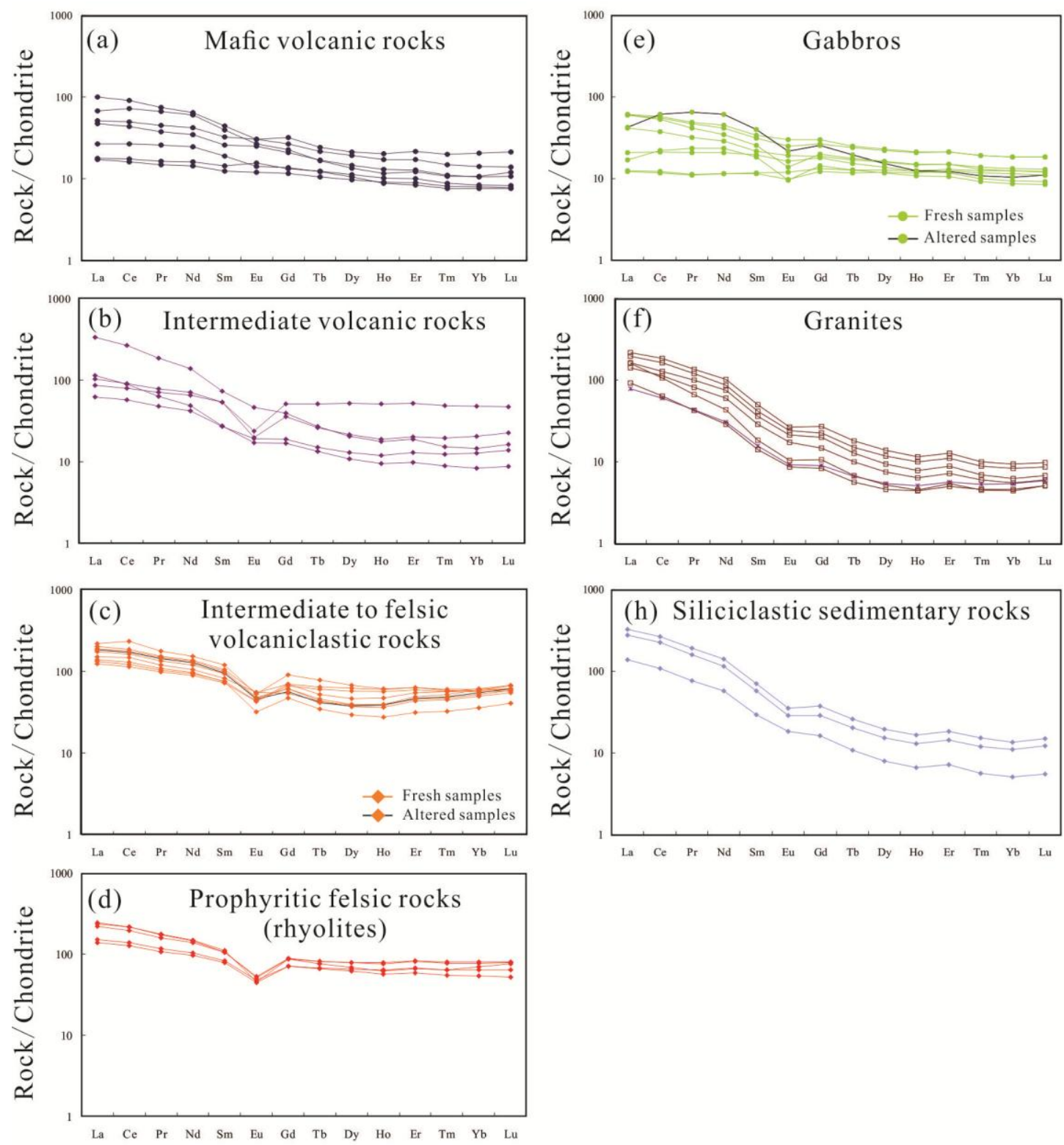

Figure 2.11. Chondrite-normalized REE diagrams for (a) mafic volcanic rocks (mostly basalt), (b) intermediate volcanic rocks, (c) intermediate to felsic volcanic rocks, (d) porphyritic felsic volcanic rocks (rhyolites), (e) felsic volcaniclastic rocks, (f) gabbros, (g) siliciclastic sedimentary rocks, and (h) the Ottertail Lake granite. Normalization values are from Sun and McDonough (1989). 

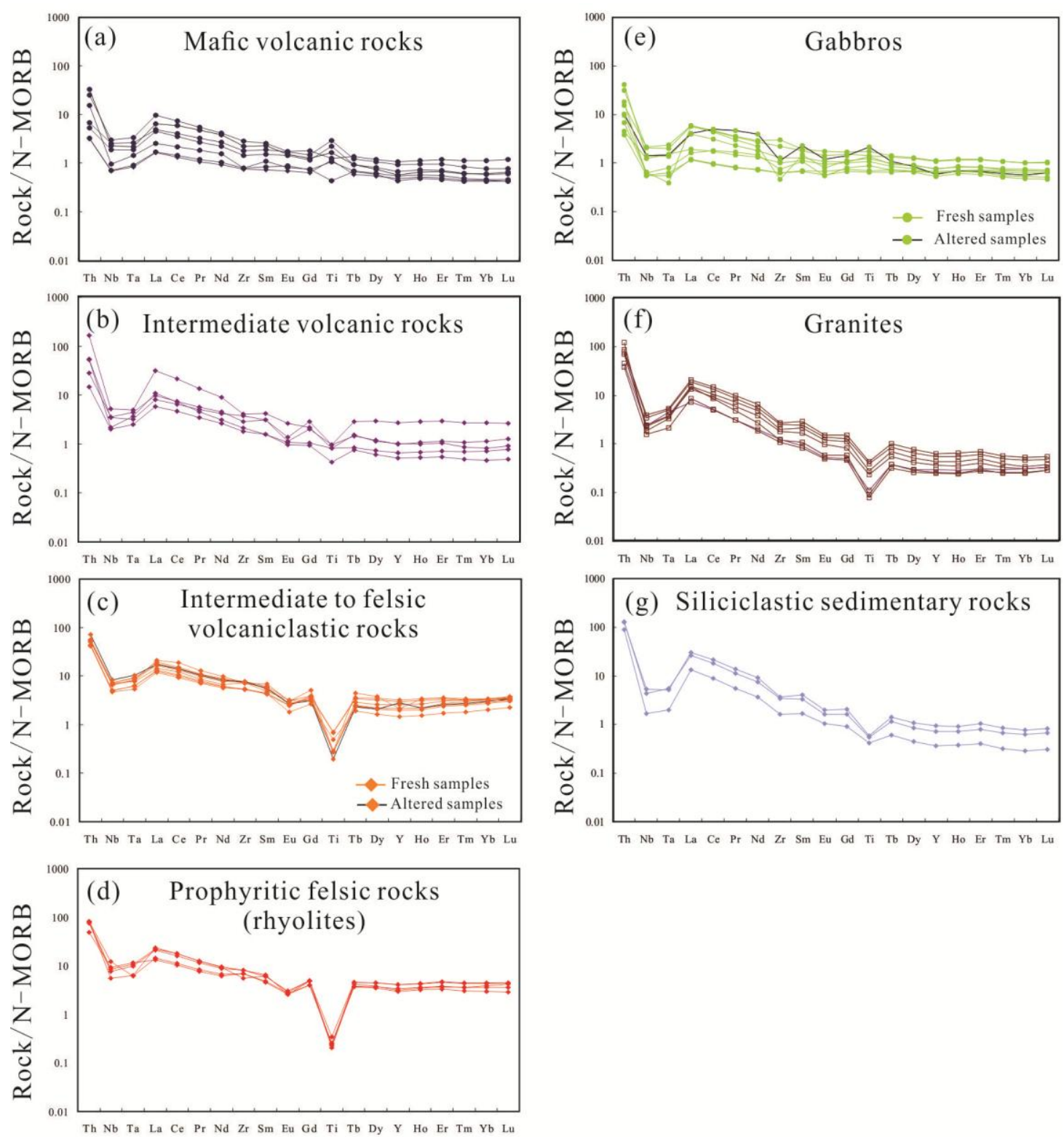

Figure 2.12. N-MORB-normalized trace element diagrams for (a) mafic volcanic rocks (mostly basalt), (b) intermediate volcanic rocks, (c) intermediate to felsic volcanic rocks, (d) porphyritic felsic volcanic rocks (rhyolites), (e) felsic volcaniclastic rocks, (f) gabbros, (g) siliciclastic sedimentary rocks, and (h) the Ottertail Lake granite. Normalization values are from Sun and McDonough (1989). 

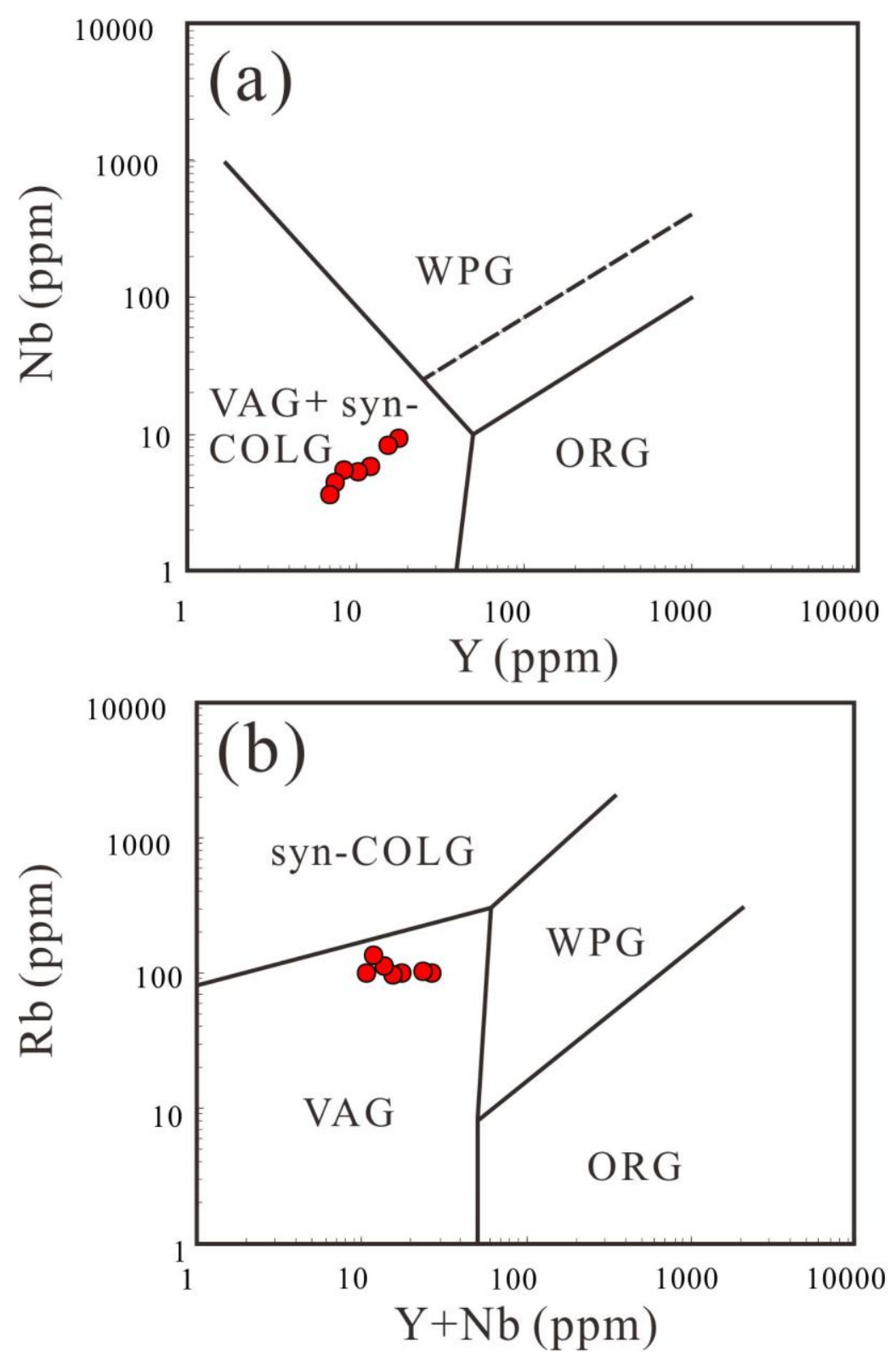

Figure 2.13. (a) $\mathrm{Nb}$ versus $\mathrm{Y}$ and (b) $\mathrm{Rb}$ versus $\mathrm{Y}+\mathrm{Nb}$ tectonic discriminant diagrams for the Ottertail Lake granite (after Pearce et al., 1984). VAG: Volcanic Arc Granite; WPG: Within Plate Granite; ORG: Ocean Ridge Granite; syn-COLG: syn-Collision Granite. 

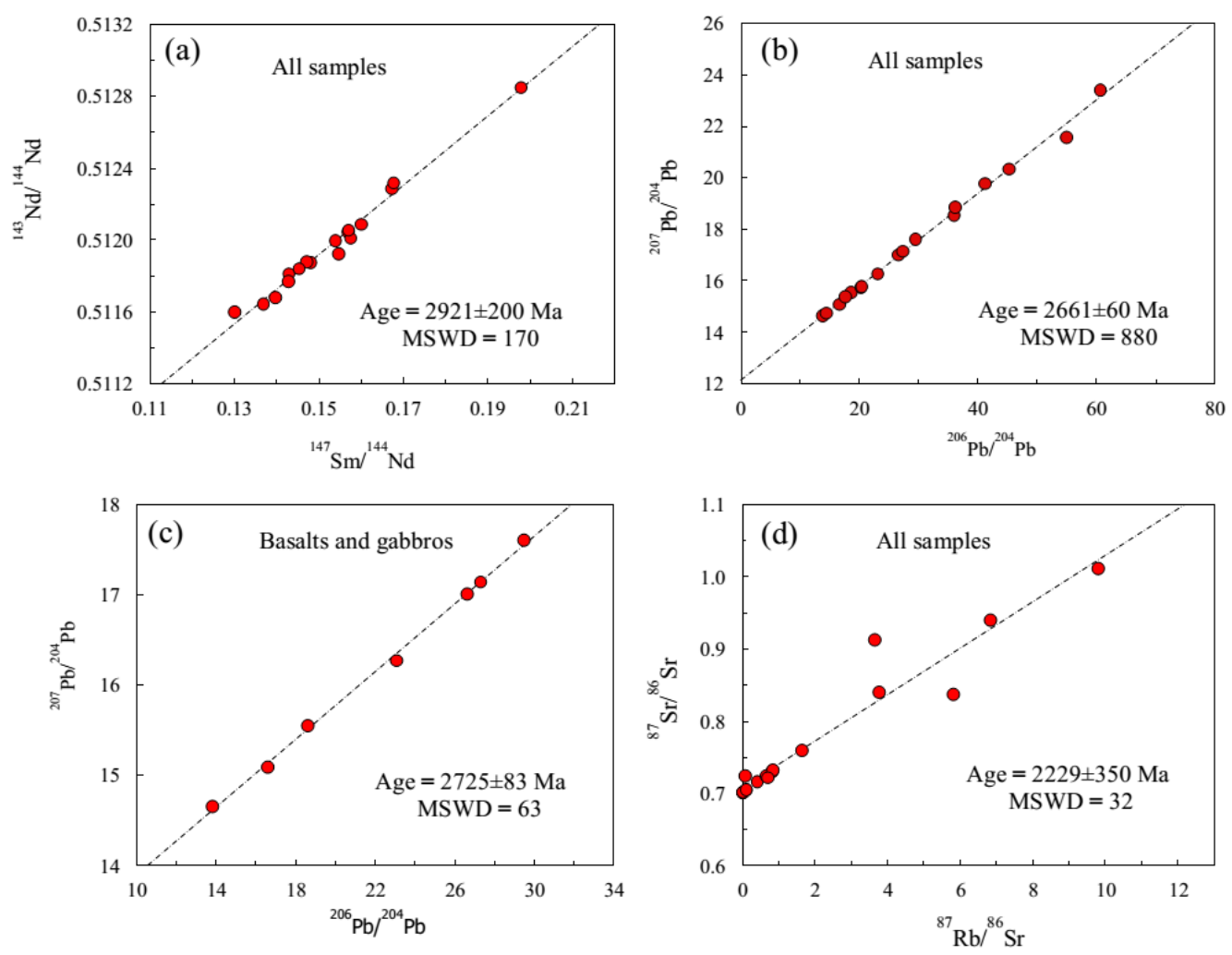

Figure 2.14. (a) ${ }^{147} \mathrm{Sm} /{ }^{144} \mathrm{Nd}$ versus ${ }^{143} \mathrm{Nd} /{ }^{144} \mathrm{Nd}$, (b) ${ }^{206} \mathrm{~Pb} /{ }^{204} \mathrm{~Pb}$ versus ${ }^{207} \mathrm{~Pb} /{ }^{204} \mathrm{~Pb}$, (c) ${ }^{206} \mathrm{~Pb} /{ }^{204} \mathrm{~Pb}$ versus ${ }^{207} \mathrm{~Pb} /{ }^{204} \mathrm{~Pb}$, and (d) ${ }^{87} \mathrm{Rb} /{ }^{86} \mathrm{Sr}$ versus ${ }^{87} \mathrm{Sr} /{ }^{86} \mathrm{Sr}$ plots for the $\mathrm{BVL}$ greenstone belt rocks. 

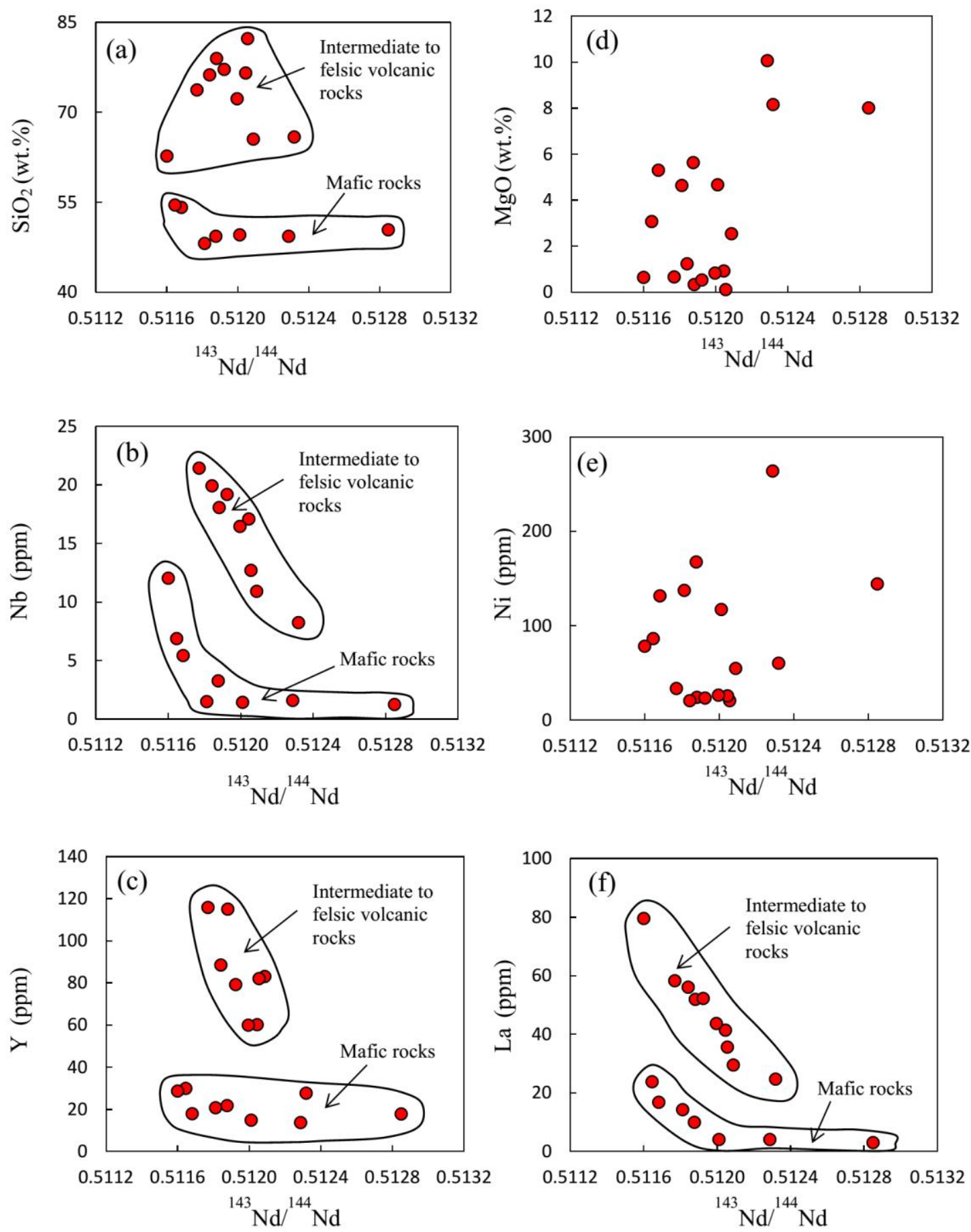

Figure 2.15. (a-f) ${ }^{143} \mathrm{Nd} /{ }^{144} \mathrm{Nd}$ versus $\mathrm{SiO}_{2}$ (wt.\%), $\mathrm{Nb}$ (ppm), $\mathrm{Y}$ (ppm), $\mathrm{MgO}$ (wt.\%), $\mathrm{Ni}(\mathrm{ppm})$ and $\mathrm{La}(\mathrm{ppm})$ plots for the BVL greenstone belt rocks. 

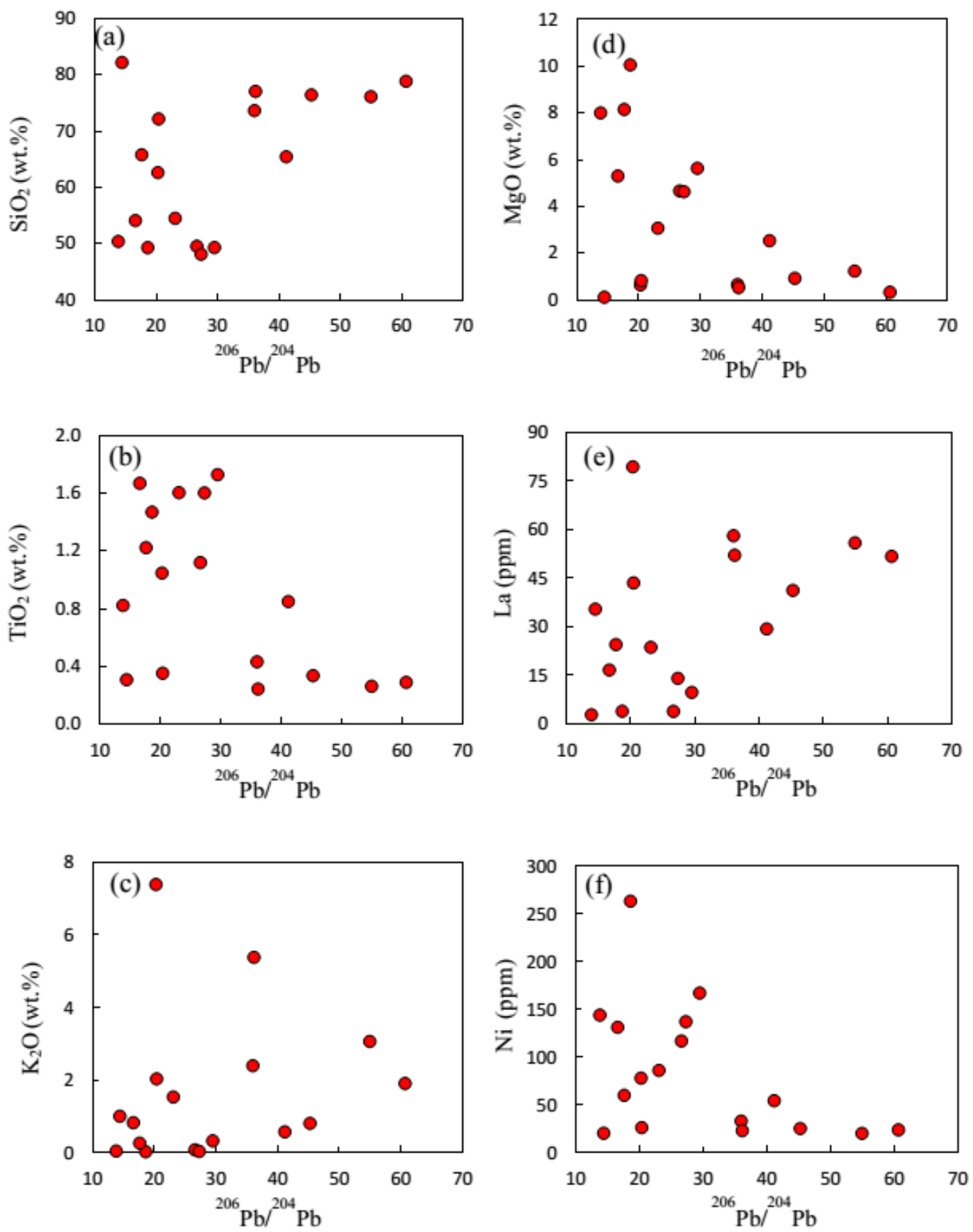

Figure 2.16. (a-f) ${ }^{206} \mathrm{~Pb} /{ }^{204} \mathrm{~Pb}$ versus $\mathrm{SiO}_{2}$ (wt.\%), $\mathrm{TiO}_{2}$ (wt.\%), $\mathrm{K}_{2} \mathrm{O}$ (wt.\%), $\mathrm{MgO}$ (wt.\%), La (ppm), and Ni (ppm) plots for the BVL greenstone belt rocks. 

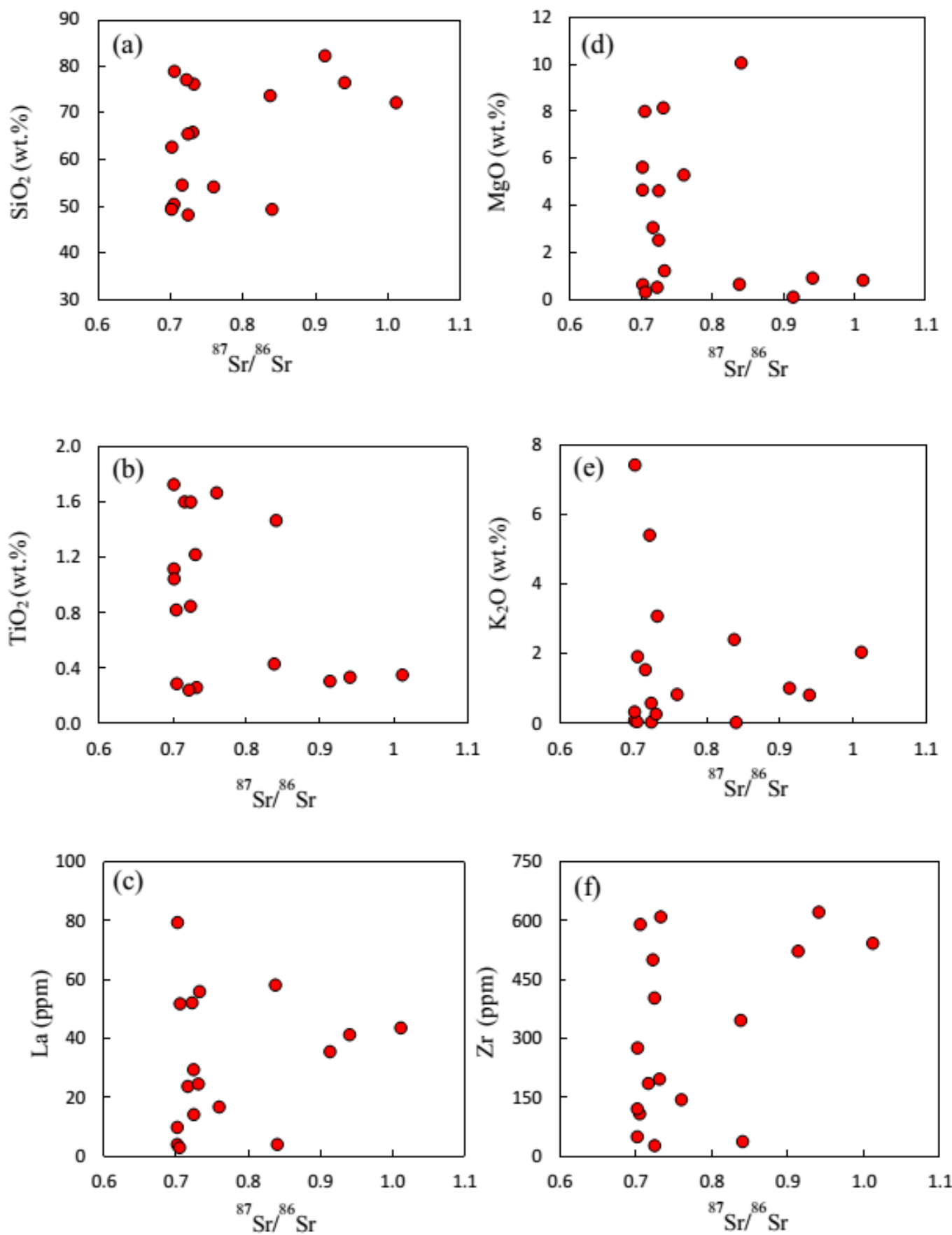

Figure 2.17. ${ }^{87} \mathrm{Sr} /{ }^{86} \mathrm{Sr}$ versus $\mathrm{SiO}_{2}$ (wt.\%), $\mathrm{TiO}_{2}$ (wt.\%), $\mathrm{La}$ (wt.\%), $\mathrm{MgO}$ (wt.\%), $\mathrm{K}_{2} \mathrm{O}$ (wt.\%), and $\mathrm{Zr}$ (ppm) plots for the BVL greenstone belt rocks. 
Table 2.1. Major (wt.\%) and trace (ppm) element concentrations and significant element ratios for the Bad Vermilion Lake greenstone belt volcanic, volcaniclastic, and sedimentary rocks.

\begin{tabular}{|c|c|c|c|c|c|c|c|c|}
\hline \multicolumn{9}{|c|}{ Mafic volcanic rocks } \\
\hline & BVL2013-001 & BVL2013-002 & BVL2013-009 & BVL2013-010 & BVL2013-011 & BVL2013-021 & BVL2013-022 & BVL2013-023 \\
\hline $\mathrm{SiO}_{2}$ & 52.5 & 53.4 & 48.5 & 54.2 & 49.3 & 54.5 & 48.6 & 49.0 \\
\hline $\mathrm{Al}_{2} \mathrm{O}_{3}$ & 13.0 & 15.8 & 16.7 & 13.1 & 15.7 & 13.4 & 12.0 & 13.4 \\
\hline $\mathrm{Fe}_{2} \mathrm{O}_{3}(\mathrm{~T})$ & 17.9 & 10.7 & 14.4 & 16.3 & 14.5 & 17.3 & 19.8 & 17.4 \\
\hline $\mathrm{MnO}$ & 0.21 & 0.22 & 0.24 & 0.21 & 0.14 & 0.23 & 0.27 & 0.24 \\
\hline $\mathrm{MgO}$ & 3.39 & 5.56 & 2.97 & 5.31 & 10.07 & 3.08 & 5.20 & 5.80 \\
\hline $\mathrm{CaO}$ & 7.36 & 9.36 & 11.81 & 6.28 & 5.34 & 6.11 & 7.90 & 7.43 \\
\hline $\mathrm{Na}_{2} \mathrm{O}$ & 2.89 & 4.19 & 3.03 & 1.93 & 3.35 & 1.81 & 1.65 & 3.22 \\
\hline $\mathrm{K}_{2} \mathrm{O}$ & 0.33 & 0.11 & 0.90 & 0.83 & 0.03 & 1.54 & 0.24 & 0.23 \\
\hline $\mathrm{TiO}_{2}$ & 2.11 & 0.56 & 1.37 & 1.67 & 1.47 & 1.60 & 3.70 & 2.81 \\
\hline $\mathrm{P}_{2} \mathrm{O}_{5}$ & 0.37 & 0.01 & 0.13 & 0.24 & 0.12 & 0.41 & 0.70 & 0.55 \\
\hline LOI & 8.67 & 9.70 & 10.04 & 7.32 & 4.25 & 9.21 & 3.37 & 7.34 \\
\hline Total & 100.2 & 98.2 & 99.6 & 99.6 & 99.9 & 100.6 & 99.6 & 99.9 \\
\hline Mg-number & 30 & 54 & 31 & 42 & 58 & 26 & 34 & 40 \\
\hline $\mathrm{Cr}$ & 22 & 103 & 278 & 19 & 250 & 9 & 9 & 53 \\
\hline Co & 49 & 23 & 61 & 47 & 58 & 38 & 51 & 48 \\
\hline $\mathrm{Ni}$ & 198 & 73 & 277 & 132 & 264 & 86 & 227 & 193 \\
\hline $\mathrm{Rb}$ & 6.2 & 2.2 & 20.7 & 16.3 & 0.4 & 30.5 & 4.9 & 3.4 \\
\hline $\mathrm{Sr}$ & 81 & 90 & 144 & 115 & 90 & 108 & 194 & 133 \\
\hline Cs & 0.19 & 0.08 & 0.69 & 0.78 & 0.13 & 0.39 & 0.32 & 0.15 \\
\hline $\mathrm{Ba}$ & 88 & 54 & 235 & 270 & 9 & 462 & 68 & 66 \\
\hline $\mathrm{Sc}$ & 35 & 24 & 25 & 34 & 27 & 27 & 44 & 38 \\
\hline $\mathrm{v}$ & 163 & 156 & 272 & 374 & 307 & 94 & 471 & 464 \\
\hline $\mathrm{Ta}$ & 0.29 & 0.19 & 0.12 & 0.38 & 0.110 & 0.443 & 0.349 & 0.251 \\
\hline $\mathrm{Nb}$ & 5.31 & 2.21 & 1.66 & 5.45 & 1.61 & 6.89 & 5.88 & 4.45 \\
\hline $\mathrm{Zr}$ & 166 & 59 & 59 & 159 & 56 & 209 & 133 & 106 \\
\hline Th & 3.88 & 1.83 & 0.39 & 2.49 & 0.38 & 3.02 & 0.82 & 0.64 \\
\hline $\mathrm{Y}$ & 16.16 & 12.21 & 15.10 & 17.80 & 13.6 & 29.9 & 25.8 & 18.7 \\
\hline $\mathrm{U}$ & 0.63 & 0.40 & 0.08 & 0.51 & 0.07 & 0.64 & 0.18 & 0.14 \\
\hline $\mathrm{La}$ & 15.89 & 6.34 & 4.20 & 16.79 & 4.07 & 23.80 & 12.13 & 11.25 \\
\hline $\mathrm{Ce}$ & 44.22 & 16.20 & 10.74 & 39.82 & 9.83 & 55.28 & 30.27 & 26.74 \\
\hline $\operatorname{Pr}$ & 6.35 & 2.44 & 1.55 & 5.14 & 1.40 & 7.12 & 4.26 & 3.59 \\
\hline $\mathrm{Nd}$ & 28.12 & 11.42 & 7.55 & 21.76 & 6.72 & 30.15 & 19.76 & 16.20 \\
\hline $\mathrm{Sm}$ & 6.05 & 2.90 & 2.17 & 5.07 & 1.90 & 6.75 & 4.95 & 3.97 \\
\hline Eu & 1.55 & 0.82 & 0.90 & 1.35 & 0.70 & 1.76 & 1.75 & 1.46 \\
\hline $\mathrm{Gd}$ & 4.65 & 2.78 & 2.72 & 4.73 & 2.37 & 6.53 & 5.49 & 4.31 \\
\hline $\mathrm{Tb}$ & 0.62 & 0.45 & 0.46 & 0.69 & 0.39 & 0.91 & 0.81 & 0.63 \\
\hline Dy & 3.42 & 2.67 & 2.84 & 3.72 & 2.46 & 5.37 & 4.91 & 3.68 \\
\hline Ho & 0.66 & 0.50 & 0.57 & & 0.51 & 1.14 & 0.98 & 0.74 \\
\hline Er & 2.01 & 1.38 & 1.65 & 2.19 & 1.48 & 3.55 & 2.82 & 2.11 \\
\hline $\mathrm{Tm}$ & 0.27 & 0.19 & 0.22 & 0.33 & 0.21 & 0.51 & 0.38 & 0.28 \\
\hline $\mathrm{Yb}$ & 1.82 & 1.28 & 1.42 & 2.32 & 1.35 & 3.47 & 2.38 & 1.80 \\
\hline $\mathrm{Lu}$ & 0.30 & 0.19 & 0.21 & 0.40 & 0.20 & 0.54 & 0.35 & 0.27 \\
\hline $\mathrm{Cu}$ & 139 & 19 & 125 & 74 & 23 & 20 & 48 & 111 \\
\hline $\mathrm{Zn}$ & 138 & 752 & 138 & 191 & 102 & 208 & 283 & 268 \\
\hline $\mathrm{Pb}$ & 2.87 & 2.14 & 3.63 & 4.51 & 1.08 & 2.49 & 6.13 & 5.89 \\
\hline $\mathrm{Al}_{2} \mathrm{O}_{3} / \mathrm{TiO}_{2}$ & 6 & 28 & 12 & 8 & 11 & 8 & 3 & 5 \\
\hline $\mathrm{Nb} / \mathrm{Ta}$ & 19 & 12 & 14 & 14 & 15 & 16 & 17 & 18 \\
\hline $\mathrm{Zr} / \mathrm{Y}$ & 10.3 & 4.8 & 3.9 & 8.9 & 4.1 & 7.0 & 5.2 & 5.7 \\
\hline $\mathrm{Ti} / \mathrm{Zr}$ & 76 & 57 & 139 & 63 & 157 & 46 & 167 & 159 \\
\hline $\mathrm{Y} / \mathrm{Ho}$ & 25 & 25 & 26 & & 27 & 26 & 26 & 25 \\
\hline $\mathrm{La} / \mathrm{Sm}_{\mathrm{n}}$ & 1.70 & 1.41 & 1.25 & 2.14 & 1.38 & 2.28 & 1.58 & 1.83 \\
\hline $\mathrm{La} / \mathrm{Yb}_{\mathrm{cn}}$ & 6.26 & 3.56 & 2.12 & 5.20 & 2.16 & 4.91 & 3.65 & 4.49 \\
\hline $\mathrm{Gd} / \mathrm{Yb}_{\mathrm{cn}}$ & 2.11 & 1.80 & 1.58 & 1.69 & 1.45 & 1.55 & 1.91 & 1.98 \\
\hline $\mathrm{Ce} / \mathrm{Ce}^{*}$ & 1.08 & 1.01 & 1.03 & 1.05 & 1.01 & 1.04 & 1.03 & 1.03 \\
\hline $\mathrm{Eu} / \mathrm{Eu}^{*}$ & 0.90 & 0.88 & 1.13 & 0.84 & 1.01 & 0.81 & 1.03 & 1.08 \\
\hline $\mathrm{Zr} / \mathrm{Zr}^{*}$ & 0.75 & 0.61 & 0.86 & 0.90 & 0.93 & 0.87 & 0.80 & 0.78 \\
\hline $\mathrm{Ti} / \mathrm{Ti}^{*}$ & 0.98 & 0.48 & 1.38 & 0.84 & 1.70 & 0.59 & 1.74 & 1.66 \\
\hline $\mathrm{Nb} / \mathrm{Nb}^{*}$ & 0.16 & 0.15 & 0.31 & 0.20 & 0.30 & 0.19 & 0.44 & 0.39 \\
\hline
\end{tabular}

a: Altered; cn: Chondrite-normalized 
Table 2.1. (Continued)

\begin{tabular}{|c|c|c|c|c|c|}
\hline & \multicolumn{5}{|c|}{ Intermediate volcanic rocks } \\
\hline & BVL2013-003 & BVL2013-012 & BVL2013-013 & BVL2013-026 & BVL2013-027 \\
\hline $\mathrm{SiO}_{2}$ & 66.6 & 59.1 & 62.7 & 62.3 & 65.9 \\
\hline $\mathrm{Al}_{2} \mathrm{O}_{3}$ & 14.6 & 14.6 & 23.6 & 13.0 & 12.7 \\
\hline $\mathrm{Fe}_{2} \mathrm{O}_{3}(\mathrm{~T})$ & 6.2 & 11.6 & 2.7 & 12.3 & 8.9 \\
\hline $\mathrm{MnO}$ & 0.15 & 0.21 & 0.02 & 0.08 & 0.04 \\
\hline $\mathrm{MgO}$ & 2.13 & 2.65 & 0.65 & 9.44 & 8.16 \\
\hline $\mathrm{CaO}$ & 4.37 & 5.63 & 0.68 & 0.74 & 0.75 \\
\hline $\mathrm{Na}_{2} \mathrm{O}$ & 3.70 & 4.19 & 0.75 & 0.03 & 1.67 \\
\hline $\mathrm{K}_{2} \mathrm{O}$ & 1.60 & 0.71 & 7.41 & 0.50 & 0.27 \\
\hline $\mathrm{TiO}_{2}$ & 0.54 & 1.03 & 1.05 & 1.23 & 1.22 \\
\hline $\mathrm{P}_{2} \mathrm{O}_{5}$ & 0.14 & 0.29 & 0.48 & 0.44 & 0.44 \\
\hline LOI & 4.81 & 5.99 & 3.00 & 4.96 & 4.20 \\
\hline Total & 100.0 & 98.4 & 100.0 & 100.9 & 100.5 \\
\hline Mg-number & 40 & 31 & 32 & 60 & 65 \\
\hline $\mathrm{Cr}$ & 47 & 15 & 17 & 12 & 10 \\
\hline Co & 15 & 25 & 6 & 11 & 13 \\
\hline $\mathrm{Ni}$ & 59 & 85 & 78 & 65 & 60 \\
\hline $\mathrm{Rb}$ & 54 & 21 & 242 & 9.0 & 4.6 \\
\hline $\mathrm{Sr}$ & 458 & 97 & 121 & 7 & 20 \\
\hline Cs & 2.43 & 0.57 & 4.04 & 0.12 & 0.04 \\
\hline $\mathrm{Ba}$ & 633 & 165 & 1227 & 110 & 89 \\
\hline $\mathrm{Sc}$ & 11 & 23 & 23 & 25 & 25 \\
\hline V & 104 & 117 & 287 & 4 & 4 \\
\hline $\mathrm{Ta}$ & 0.490 & 0.331 & 0.656 & 0.420 & 0.594 \\
\hline $\mathrm{Nb}$ & 5.17 & 4.64 & 12.04 & 8.01 & 8.26 \\
\hline $\mathrm{Zr}$ & 159 & 134 & 305 & 283 & 214 \\
\hline Th & 6.26 & 1.78 & 19.98 & 6.54 & 3.41 \\
\hline $\mathrm{Y}$ & 14.3 & 18.3 & 28.6 & 77.0 & 27.6 \\
\hline $\mathrm{U}$ & 1.31 & 0.40 & 4.85 & 0.71 & 0.49 \\
\hline $\mathrm{La}$ & 27.03 & 14.69 & 79.51 & 20.34 & 24.64 \\
\hline $\mathrm{Ce}$ & 54.64 & 35.34 & 162.62 & 49.00 & 55.40 \\
\hline $\mathrm{Pr}$ & 6.03 & 4.57 & 17.67 & 6.70 & 7.43 \\
\hline $\mathrm{Nd}$ & 22.66 & 19.50 & 65.15 & 30.60 & 32.98 \\
\hline $\mathrm{Sm}$ & 4.20 & 4.17 & 11.19 & 8.26 & 8.18 \\
\hline $\mathrm{Eu}$ & 1.00 & 1.11 & 2.70 & 1.39 & 1.16 \\
\hline $\mathrm{Gd}$ & 3.46 & 3.87 & 8.07 & 10.52 & 7.35 \\
\hline $\mathrm{Tb}$ & 0.50 & 0.56 & 1.02 & 1.91 & 0.99 \\
\hline Dy & 2.77 & 3.32 & 5.25 & 13.32 & 5.47 \\
\hline Ho & 0.53 & 0.68 & 1.00 & 2.89 & 1.08 \\
\hline $\mathrm{Er}$ & 1.62 & 2.15 & 3.13 & 8.67 & 3.36 \\
\hline $\mathrm{Tm}$ & 0.23 & 0.32 & 0.39 & 1.25 & 0.50 \\
\hline $\mathrm{Yb}$ & 1.43 & 2.18 & 2.48 & 8.20 & 3.47 \\
\hline $\mathrm{Lu}$ & 0.22 & 0.35 & 0.41 & 1.20 & 0.58 \\
\hline $\mathrm{Cu}$ & 36 & 33 & 21 & 12 & 11 \\
\hline $\mathrm{Zn}$ & 70 & 152 & 186 & 164 & 129 \\
\hline $\mathrm{Pb}$ & 7.91 & 1.95 & 30.50 & 7.00 & 10.91 \\
\hline $\mathrm{Al}_{2} \mathrm{O}_{3} / \mathrm{TiO}_{2}$ & 27 & 14 & 23 & 11 & 10 \\
\hline $\mathrm{Nb} / \mathrm{Ta}$ & 11 & 14 & 18 & 19 & 14 \\
\hline $\mathrm{Zr} / \mathrm{Y}$ & 11.1 & 7.3 & 10.7 & 3.7 & 7.8 \\
\hline $\mathrm{Ti} / \mathrm{Zr}$ & 21 & 46 & 21 & 26 & 34 \\
\hline $\mathrm{Y} / \mathrm{Ho}$ & 27 & 27 & 29 & 27 & 26 \\
\hline $\mathrm{La} / \mathrm{Sm}_{\mathrm{en}}$ & 4.15 & 2.27 & 4.59 & 1.59 & 1.94 \\
\hline $\mathrm{La} / \mathrm{Yb}_{\mathrm{cn}}$ & 13.58 & 4.83 & 22.95 & 1.78 & 5.09 \\
\hline $\mathrm{Gd} / \mathrm{Yb}_{\mathrm{cn}}$ & 2.01 & 1.47 & 2.69 & 1.06 & 1.75 \\
\hline $\mathrm{Ce} / \mathrm{Ce}^{*}$ & 1.05 & 1.06 & 1.06 & 1.03 & 1.00 \\
\hline $\mathrm{Eu} / \mathrm{Eu}^{*}$ & 0.80 & 0.84 & 0.87 & 0.46 & 0.46 \\
\hline $\mathrm{Zr} / \mathrm{Zr}^{*}$ & 0.96 & 0.88 & 0.67 & 1.05 & 0.77 \\
\hline $\mathrm{Ti} / \mathrm{Ti}^{*}$ & 0.35 & 0.63 & 0.27 & 0.32 & 0.39 \\
\hline $\mathrm{Nb} / \mathrm{Nb}^{*}$ & 0.09 & 0.21 & 0.07 & 0.16 & 0.21 \\
\hline North & 532351 & 535091 & 535997 & 522085 & 520799 \\
\hline East & 5399420 & 5399610 & 5399400 & 5400301 & 5399678 \\
\hline
\end{tabular}


Table 2.1. (Continued)

\begin{tabular}{|c|c|c|c|c|c|c|c|c|}
\hline & \multicolumn{8}{|c|}{ Intermediate to felsic volcaniclastic rocks } \\
\hline & BVL2013-004 & BVL2013-005 & BVL2013-006 & BVL2013-007 & BVL2013-008 & BVL2013-015 & BVL2013-024 & BVL2013-036 \\
\hline $\mathrm{SiO}_{2}$ & 74.2 & 74.6 & 76.5 & 73.5 & 72.3 & 66.7 & 67.3 & 77.2 \\
\hline $\mathrm{Al}_{2} \mathrm{O}_{3}$ & 10.4 & 11.1 & 11.1 & 10.9 & 11.3 & 16.2 & 10.6 & 11.4 \\
\hline $\mathrm{Fe}_{2} \mathrm{O}_{3}(\mathrm{~T})$ & 10.4 & 7.8 & 5.9 & 11.9 & 6.8 & 4.8 & 17.7 & 2.7 \\
\hline $\mathrm{MnO}$ & 0.04 & 0.07 & 0.08 & 0.06 & 0.26 & 0.09 & 0.08 & 0.03 \\
\hline $\mathrm{MgO}$ & 3.40 & 1.19 & 0.93 & 1.86 & 0.83 & 0.98 & 3.05 & 0.53 \\
\hline $\mathrm{CaO}$ & 0.09 & 1.35 & 1.06 & 0.09 & 5.24 & 2.85 & 0.19 & 0.41 \\
\hline $\mathrm{Na}_{2} \mathrm{O}$ & 0.09 & 2.93 & 3.18 & 0.14 & 0.87 & 3.52 & 0.03 & 2.18 \\
\hline $\mathrm{K}_{2} \mathrm{O}$ & 0.96 & 0.56 & 0.82 & 1.21 & 2.04 & 3.77 & 0.32 & 5.40 \\
\hline $\mathrm{TiO}_{2}$ & 0.34 & 0.34 & 0.34 & 0.36 & 0.35 & 0.74 & 0.63 & 0.24 \\
\hline $\mathrm{P}_{2} \mathrm{O}_{5}$ & 0.04 & 0.04 & 0.04 & 0.04 & 0.04 & 0.35 & 0.12 & 0.01 \\
\hline LOI & 2.89 & 2.58 & 2.21 & 2.62 & 6.04 & 4.41 & 3.09 & 0.25 \\
\hline Total & 99.6 & 100.9 & 100.2 & 98.4 & 98.5 & 100.6 & 99.5 & 99.6 \\
\hline Mg-number & 42.1 & 25.4 & 26 & 26 & 21 & 29 & 25 & 31 \\
\hline $\mathrm{Cr}$ & 23 & 21 & 23 & 11 & 16 & 52 & 22 & 18 \\
\hline Co & 5 & 2 & 2 & 4 & 2 & 12 & 15 & 1 \\
\hline $\mathrm{Ni}$ & 26 & 26 & 25 & 27 & 26 & 72 & 43 & 23 \\
\hline $\mathrm{Rb}$ & 19 & 12 & 19 & 21 & 41 & 116 & 4.7 & 93 \\
\hline $\mathrm{Sr}$ & 15 & 25 & 34 & 11 & 32 & 532 & 6 & 39 \\
\hline Cs & 0.77 & 0.54 & 0.9 & 0.76 & 1.49 & 3.04 & 0.09 & 0.66 \\
\hline $\mathrm{Ba}$ & 384 & 69 & 137 & 482 & 212 & 1172 & 103 & 1134 \\
\hline $\mathrm{Sc}$ & 3 & 3 & 3 & 3 & 3 & 11 & 11 & 2 \\
\hline $\mathrm{v}$ & 7 & 6 & 4.4 & 4.5 & 5.5 & 84 & 33 & 0.59 \\
\hline $\mathrm{Ta}$ & 1.07 & 1.18 & 1.22 & 1.09 & 1.02 & 0.67 & 0.82 & 1.35 \\
\hline $\mathrm{Nb}$ & 15.14 & 16.71 & 17.11 & 15.58 & 16.47 & 12.37 & 11.81 & 19.19 \\
\hline $\mathrm{Zr}$ & 529 & 572 & 562 & 526 & 544 & 274 & 383 & 573 \\
\hline Th & 6.06 & 6.77 & 6.60 & 6.24 & 6.66 & 15.31 & 4.99 & 8.49 \\
\hline $\mathrm{Y}$ & 55 & 71 & 60 & 59 & 60 & 27 & 41 & 79 \\
\hline U & 1.31 & 1.41 & 1.54 & 1.32 & 1.41 & 3.31 & 1.05 & 2.22 \\
\hline $\mathrm{La}$ & 45.11 & 47.69 & 41.36 & 35.83 & 43.68 & 76.49 & 33.12 & 52.23 \\
\hline $\mathrm{Ce}$ & 108.72 & 113.23 & 99.43 & 91.16 & 104.46 & 163.97 & 79.32 & 142.78 \\
\hline $\mathrm{Pr}$ & 14.08 & 14.54 & 12.76 & 11.29 & 13.59 & 18.22 & 10.30 & 16.82 \\
\hline $\mathrm{Nd}$ & 61.97 & 64.03 & 55.94 & 49.36 & 59.68 & 66.32 & 45.13 & 71.96 \\
\hline $\mathrm{Sm}$ & 15.35 & 16.01 & 14.22 & 12.60 & 14.46 & 10.76 & 11.35 & 18.25 \\
\hline Eu & 2.79 & 3.18 & 2.76 & 3.24 & 2.67 & 2.04 & 1.86 & 3.09 \\
\hline Gd & 12.58 & 14.33 & 12.57 & 11.07 & 11.58 & 7.67 & 9.73 & 18.78 \\
\hline $\mathrm{Tb}$ & 1.62 & 1.94 & 1.69 & 1.61 & 1.55 & 0.97 & 1.29 & 2.95 \\
\hline Dy & 9.34 & 11.73 & 9.94 & 9.89 & 9.56 & 4.96 & 7.46 & 17.25 \\
\hline Ho & 2.07 & 2.65 & 2.23 & 2.20 & 2.19 & 0.94 & 1.57 & 3.45 \\
\hline $\mathrm{Er}$ & 7.15 & 9.05 & 8.03 & 7.54 & 7.72 & 3.07 & 5.16 & 10.41 \\
\hline $\mathrm{Tm}$ & 1.15 & 1.44 & 1.33 & 1.21 & 1.24 & 0.39 & 0.82 & 1.48 \\
\hline $\mathrm{Yb}$ & 8.36 & 10.39 & 10 & 8.86 & 9.36 & 2.32 & 6.11 & 9.99 \\
\hline Lu & 1.39 & 1.70 & 1.7 & 1.47 & 1.55 & 0.38 & 1.03 & 1.53 \\
\hline $\mathrm{Cu}$ & 5.01 & 5.72 & 6.5 & 7.65 & 7.90 & 22 & 7 & 4 \\
\hline $\mathrm{Zn}$ & 71.25 & 124.42 & 145 & 135.55 & 151.67 & 145 & 208 & 63 \\
\hline $\mathrm{Pb}$ & 7.66 & 2.26 & 1.32 & 4.18 & 11.46 & 21.52 & 4.28 & 5.00 \\
\hline $\mathrm{Al}_{2} \mathrm{O}_{3} / \mathrm{TiO}_{2}$ & 31 & 33 & 33 & 30 & 32 & 22 & 17 & 47 \\
\hline $\mathrm{Nb} / \mathrm{Ta}$ & 14 & 14 & 14 & 14 & 16 & 18 & 14 & 14 \\
\hline $\mathrm{Zr} / \mathrm{Y}$ & 9.5 & 8.0 & 9.4 & 8.9 & 9.1 & 10.3 & 9.4 & 7.2 \\
\hline $\mathrm{T} / / Z \mathrm{r}$ & 4 & 4 & 4 & 4 & 4 & 16 & 10 & 3 \\
\hline Y/Ho & 27 & 27 & 27 & 27 & 27 & 28 & 26 & 23 \\
\hline $\mathrm{La} / \mathrm{Sm}_{\mathrm{en}}$ & 1.90 & 1.92 & 1.88 & 1.84 & 1.95 & 4.59 & 1.88 & 1.85 \\
\hline $\mathrm{La} / \mathrm{Yb}_{\mathrm{cn}}$ & 3.87 & 3.29 & 2.94 & 2.90 & 3.35 & 23.62 & 3.89 & 3.75 \\
\hline $\mathrm{Gd} / \mathrm{Yb}_{\mathrm{cn}}$ & 1.24 & 1.14 & 1.03 & 1.03 & 1.02 & 2.73 & 1.32 & 1.55 \\
\hline $\mathrm{Ce} / \mathrm{Ce}^{*}$ & 1.06 & 1.05 & 1.06 & 1.11 & 1.05 & 1.08 & 1.05 & 1.18 \\
\hline $\mathrm{Eu} / \mathrm{Eu}^{*}$ & 0.61 & 0.64 & 0.63 & 0.84 & 0.63 & 0.69 & 0.54 & 0.51 \\
\hline $\mathrm{Zr} / \mathrm{Zr}^{*}$ & 1.02 & 1.06 & 1.18 & 1.25 & 1.10 & 0.61 & 1.00 & 0.94 \\
\hline $\mathrm{Ti} / \mathrm{Ti}^{*}$ & 0.06 & 0.05 & 0.06 & 0.08 & 0.07 & 0.20 & 0.15 & 0.03 \\
\hline $\mathrm{Nb} / \mathrm{Nb}^{*}$ & 0.22 & 0.22 & 0.24 & 0.25 & 0.23 & 0.08 & 0.22 & 0.21 \\
\hline North & 533170 & 533659 & 533342 & 533630 & 533693 & 536776 & 525528 & 514160 \\
\hline East & 5399620 & 5399659 & 5399662 & 5399666 & 5399650 & 5399101 & 5400865 & 5394956 \\
\hline
\end{tabular}


Table 2.1. (Continued)

\begin{tabular}{|c|c|c|c|c|c|c|c|}
\hline & \multicolumn{2}{|c|}{ Volcaniclastic rocks } & \multicolumn{4}{|c|}{ Porphyritic felsic rocks (rhyolite) } & \multirow[b]{2}{*}{ BVL2013-037 } \\
\hline & BVL2013-038 & BVL2013-039 & BVL2013-030 & BVL2013-031 & BVL2013-033 & BVL2013-034 & \\
\hline $\mathrm{SiO}_{2}$ & 65.5 & 66.0 & 79.0 & 73.7 & 82.3 & 76.7 & 76.2 \\
\hline $\mathrm{Al}_{2} \mathrm{O}_{3}$ & 12.3 & 12.0 & 11.0 & 10.9 & 9.2 & 10.1 & 12.2 \\
\hline $\mathrm{Fe}_{2} \mathrm{O}_{3}(\mathrm{~T})$ & 11.7 & 11.5 & 3.3 & 6.2 & 2.1 & 6.1 & 4.7 \\
\hline $\mathrm{MnO}$ & 0.13 & 0.11 & 0.07 & 0.08 & 0.05 & 0.13 & 0.06 \\
\hline $\mathrm{MgO}$ & 2.54 & 2.28 & 0.33 & 0.66 & 0.12 & 0.36 & 1.24 \\
\hline $\mathrm{CaO}$ & 2.19 & 2.34 & 1.12 & 2.47 & 2.15 & 1.65 & 0.32 \\
\hline $\mathrm{Na}_{2} \mathrm{O}$ & 4.00 & 4.12 & 2.99 & 3.01 & 2.70 & 2.48 & 1.97 \\
\hline $\mathrm{K}_{2} \mathrm{O}$ & 0.58 & 0.50 & 1.92 & 2.41 & 1.01 & 2.14 & 3.08 \\
\hline $\mathrm{TiO}_{2}$ & 0.85 & 0.88 & 0.29 & 0.43 & 0.31 & 0.33 & 0.26 \\
\hline $\mathrm{P}_{2} \mathrm{O}_{5}$ & 0.19 & 0.21 & 0.02 & 0.05 & 0.03 & 0.04 & 0.01 \\
\hline LOI & 1.21 & 0.72 & 1.06 & 1.44 & 0.78 & 0.86 & 1.14 \\
\hline Total & 100.8 & 100.0 & 100.2 & 100.7 & 99.5 & 100.5 & 98.0 \\
\hline Mg-number & 30 & 28 & 17 & 17 & 10 & 10 & 34 \\
\hline $\mathrm{Cr}$ & 15 & 29 & 18 & 15 & 36 & 28 & 13 \\
\hline Co & 13 & 13 & 1 & 3 & 1 & 2 & 1 \\
\hline $\mathrm{Ni}$ & 55 & 59 & 24 & 33 & 20 & 43 & 20 \\
\hline $\mathrm{Rb}$ & 10.4 & 9.7 & 39 & 70 & 20 & 52 & 52 \\
\hline $\mathrm{Sr}$ & 43 & 53 & 20 & 55 & 67 & 32 & 15 \\
\hline Cs & 0.31 & 0.30 & 0.32 & 0.97 & 0.25 & 0.86 & 0.54 \\
\hline $\mathrm{Ba}$ & 87 & 81 & 248 & 581 & 178 & 275 & 1034 \\
\hline $\mathrm{Sc}$ & 16 & 17 & 4 & 8 & 3 & 4 & 2 \\
\hline $\mathrm{v}$ & 43 & 45 & 1 & 3 & 1 & 1 & 0 \\
\hline $\mathrm{Ta}$ & 0.72 & 0.83 & 1.305 & 1.520 & 0.833 & 0.813 & 1.401 \\
\hline $\mathrm{Nb}$ & 10.93 & 11.51 & 18.09 & 21.43 & 12.71 & 28.19 & 19.94 \\
\hline $\mathrm{Zr}$ & 403 & 398 & 594 & 405 & 512 & 506 & 598 \\
\hline Th & 4.98 & 5.20 & 9.07 & 9.86 & 9.76 & 5.79 & 9.56 \\
\hline $\mathrm{Y}$ & 83 & 90 & 115.0 & 115.8 & 82.0 & 94.0 & 88.4 \\
\hline U & 1.13 & 1.16 & 2.00 & 2.16 & 1.33 & 1.25 & 2.13 \\
\hline $\mathrm{La}$ & 29.48 & 31.05 & 51.88 & 58.24 & 35.60 & 32.99 & 56.03 \\
\hline $\mathrm{Ce}$ & 69.59 & 74.51 & 120.02 & 132.39 & 84.85 & 77.67 & 133.27 \\
\hline $\operatorname{Pr}$ & 9.27 & 9.74 & 15.10 & 16.34 & 11.04 & 10.18 & 16.71 \\
\hline Nd & 41.53 & 43.53 & 64.40 & 67.75 & 48.62 & 45.25 & 69.92 \\
\hline $\mathrm{Sm}$ & 11.09 & 11.61 & 15.98 & 16.18 & 12.59 & 11.99 & 16.92 \\
\hline Eu & 2.46 & 2.54 & 3.08 & 2.94 & 2.76 & 2.60 & 2.61 \\
\hline Gd & 13.58 & 14.34 & 18.15 & 17.87 & 14.57 & 14.54 & 17.82 \\
\hline $\mathrm{Tb}$ & 2.25 & 2.42 & 3.07 & 3.06 & 2.46 & 2.50 & 2.86 \\
\hline Dy & 14.69 & 15.87 & 20.14 & 20.06 & 15.63 & 16.65 & 17.29 \\
\hline Ho & 3.18 & 3.43 & 4.43 & 4.31 & 3.23 & 3.62 & 3.51 \\
\hline $\mathrm{Er}$ & 9.76 & 10.51 & 13.80 & 13.46 & 9.72 & 11.11 & 10.91 \\
\hline $\mathrm{Tm}$ & 1.43 & 1.54 & 2.02 & 1.97 & 1.39 & 1.63 & 1.64 \\
\hline $\mathrm{Yb}$ & 9.56 & 10.24 & 13.54 & 13.20 & 9.10 & 10.93 & 11.89 \\
\hline Lu & 1.47 & 1.56 & 2.02 & 2.01 & 1.32 & 1.62 & 1.94 \\
\hline $\mathrm{Cu}$ & 8 & 8 & 11 & 4 & 8 & 41 & 5 \\
\hline $\mathrm{Zn}$ & 212 & 149 & 95 & 101 & 440 & 176 & 129 \\
\hline $\mathrm{Pb}$ & 8.59 & 5.06 & 3.03 & 5.84 & 36.53 & 3.30 & 6.06 \\
\hline $\mathrm{Al}_{2} \mathrm{O}_{3} / \mathrm{TiO}_{2}$ & 14 & 14 & 38 & 25 & 30 & 31 & 46 \\
\hline $\mathrm{Nb} / \mathrm{Ta}$ & 15 & 14 & 14 & 14 & 15 & 35 & 14 \\
\hline $\mathrm{Zr} / \mathrm{Y}$ & 4.9 & 4.4 & 5.2 & 3.5 & 6.2 & 5.4 & 6.8 \\
\hline $\mathrm{Ti} / \mathrm{Zr}$ & 13 & 13 & 3 & 6 & 4 & 4 & 3 \\
\hline $\mathrm{Y} / \mathrm{Ho}$ & 26 & 26 & 26 & 27 & 25 & 26 & 25 \\
\hline $\mathrm{La} / \mathrm{Sm}_{\mathrm{cn}}$ & 1.72 & 1.73 & 2.10 & 2.32 & 1.83 & 1.78 & 2.14 \\
\hline $\mathrm{La} / \mathrm{Yb}_{\mathrm{cn}}$ & 2.21 & 2.18 & 2.75 & 3.17 & 2.81 & 2.17 & 3.38 \\
\hline $\mathrm{Gd} / \mathrm{Yb}_{\mathrm{cn}}$ & 1.18 & 1.16 & 1.11 & 1.12 & 1.32 & 1.10 & 1.24 \\
\hline $\mathrm{Ce} / \mathrm{Ce}^{*}$ & 1.03 & 1.05 & 1.05 & 1.05 & 1.05 & 1.04 & 1.07 \\
\hline $\mathrm{Eu} / \mathrm{Eu}^{*}$ & 0.61 & 0.60 & 0.55 & 0.53 & 0.62 & 0.60 & 0.46 \\
\hline $\mathrm{Zr} / \mathrm{Zr}^{*}$ & 1.11 & 1.05 & 1.10 & 0.72 & 1.23 & 1.29 & 1.03 \\
\hline $\mathrm{Ti} / \mathrm{Ti}^{*}$ & 0.17 & 0.17 & 0.04 & 0.06 & 0.06 & 0.06 & 0.04 \\
\hline $\mathrm{Nb} / \mathrm{Nb}^{*}$ & 0.21 & 0.21 & 0.20 & 0.21 & 0.16 & 0.48 & 0.20 \\
\hline North & 514940 & 514940 & 518966 & 518921 & 515548 & 515525 & 514671 \\
\hline East & 5394460 & 5394460 & 5399537 & 5399556 & 5395295 & 5395228 & 5394823 \\
\hline
\end{tabular}


Table 2.1. (Continued)

\begin{tabular}{|c|c|c|c|c|c|c|c|c|c|}
\hline & \multicolumn{9}{|c|}{ Gabbros } \\
\hline & BVL2013-018" & BVL2013-019 & BVL2013-020 & BVL2013-025 & BVL2013-028 & BVL2013-029 & BVL2013-032 & BVL2013-035 & BVL2013-040 \\
\hline $\mathrm{SiO}_{2}$ & 44.7 & 49.6 & 48.1 & 50.4 & 52.2 & 49.3 & 50.3 & 48.3 & 49.8 \\
\hline $\mathrm{Al}_{2} \mathrm{O}_{3}$ & 11.4 & 17.9 & 18.2 & 15.3 & 13.0 & 13.3 & 15.6 & 14.6 & 13.5 \\
\hline $\mathrm{Fe}_{2} \mathrm{O}_{3}(\mathrm{~T})$ & 26.1 & 16.0 & 15.2 & 16.4 & 16.9 & 16.6 & 13.6 & 15.4 & 17.7 \\
\hline $\mathrm{MnO}$ & 0.23 & 0.16 & 0.15 & 0.23 & 0.22 & 0.22 & 0.21 & 0.27 & 0.22 \\
\hline $\mathrm{MgO}$ & 5.58 & 4.67 & 4.64 & 8.01 & 4.26 & 5.64 & 5.84 & 6.64 & 4.25 \\
\hline $\mathrm{CaO}$ & 9.05 & 5.96 & 10.09 & 7.13 & 7.72 & 10.52 & 10.84 & 8.87 & 8.37 \\
\hline $\mathrm{Na}_{2} \mathrm{O}$ & 0.04 & 4.37 & 1.80 & 1.59 & 2.79 & 2.17 & 2.13 & 3.07 & 2.65 \\
\hline $\mathrm{K}_{2} \mathrm{O}$ & 0.01 & 0.09 & 0.04 & 0.05 & 0.82 & 0.33 & 0.54 & 1.35 & 0.86 \\
\hline $\mathrm{TiO}_{2}$ & 2.69 & 1.12 & 1.60 & 0.82 & 1.83 & 1.73 & 0.90 & 1.38 & 2.18 \\
\hline $\mathrm{P}_{2} \mathrm{O}_{5}$ & 0.19 & 0.12 & 0.10 & 0.06 & 0.27 & 0.16 & 0.06 & 0.09 & 0.43 \\
\hline LOI & 8.85 & 6.73 & 4.52 & 4.03 & 1.48 & 2.26 & 2.08 & 1.08 & 0.99 \\
\hline Total & 100.1 & 100.3 & 100.9 & 100.5 & 100.4 & 100.8 & 100.5 & 99.5 & 99.1 \\
\hline Mg-number & 32 & 39 & 40 & 52 & 33 & 40 & 46 & 46 & 32 \\
\hline $\mathrm{Cr}$ & 11 & 39 & 22 & 203 & 70 & 50 & 196 & 191 & 11 \\
\hline Co & 83 & 53 & 49 & 50 & 47 & 58 & 47 & 55 & 49 \\
\hline $\mathrm{Ni}$ & 197 & 117 & 137 & 144 & 149 & 167 & 118 & 196 & 153 \\
\hline $\mathrm{Rb}$ & 0.62 & 1.37 & 1.04 & 1.26 & 19 & 7.1 & 18 & 46 & 22 \\
\hline $\mathrm{Sr}$ & 58 & 41 & 154 & 160 & 161 & 182 & 127 & 128 & 242 \\
\hline Cs & 0.08 & 0.05 & 0.12 & 0.12 & 0.55 & 0.22 & 0.32 & 1.78 & 0.64 \\
\hline Ba & 5.30 & 24.24 & 12.82 & 19 & 233 & 91 & 109 & 437 & 236 \\
\hline Sc & 43 & 38 & 32 & 47 & 34 & 37 & 42 & 31 & 31 \\
\hline v & 803 & 418 & 602 & 305 & 405 & 590 & 303 & 311 & 433 \\
\hline $\mathrm{Ta}$ & 0.20 & 0.11 & 0.05 & 0.07 & 0.265 & 0.184 & 0.084 & 0.200 & 0.310 \\
\hline $\mathrm{Nb}$ & 3.33 & 1.45 & 1.51 & 1.26 & 4.83 & 3.27 & 1.31 & 2.85 & 4.98 \\
\hline $\mathrm{Zr}$ & 83 & 55 & 34 & 46 & 162 & 96 & 47 & 76 & 219 \\
\hline Th & 1.21 & 0.83 & 1.14 & 2.20 & 3.79 & 4.90 & 0.46 & 0.55 & 1.84 \\
\hline Y & 16.22 & 14.79 & 20.70 & 18 & 30 & 22 & 19 & 17 & 31 \\
\hline U & 0.34 & 0.33 & 0.42 & 0.06 & 0.45 & 0.27 & 0.04 & 0.09 & 0.36 \\
\hline La & 10.08 & 4.04 & 14.21 & 2.98 & 14.36 & 9.88 & 2.88 & 4.90 & 14.65 \\
\hline $\mathrm{Ce}$ & 37.27 & 13.57 & 32.43 & 7.46 & 34.19 & 23.00 & 7.19 & 13.08 & 35.17 \\
\hline Pr & 6.20 & 2.25 & 3.94 & 1.08 & 4.48 & 3.02 & 1.06 & 1.97 & 4.68 \\
\hline $\mathrm{Nd}$ & 28.70 & 10.91 & 16.22 & 5.34 & 19.58 & 13.36 & 5.41 & 9.82 & 20.93 \\
\hline Sm & 6.11 & 2.81 & 3.89 & 1.78 & 4.79 & 3.35 & 1.82 & 3.00 & 5.17 \\
\hline Eu & 1.25 & 0.56 & 0.80 & 0.57 & 1.46 & 1.11 & 0.70 & 0.95 & 1.76 \\
\hline Gd & 5.26 & 2.94 & 4.10 & 2.51 & 5.52 & 3.85 & 2.71 & 3.75 & 6.13 \\
\hline $\mathrm{Tb}$ & 0.74 & 0.48 & 0.66 & 0.44 & 0.89 & 0.63 & 0.48 & 0.57 & 0.94 \\
\hline Dy & 3.89 & 2.99 & 4.17 & 3.05 & 5.60 & 4.02 & 3.23 & 3.52 & 5.85 \\
\hline Но & 0.71 & 0.62 & 0.86 & 0.67 & 1.17 & 0.84 & 0.71 & 0.69 & 1.21 \\
\hline $\mathrm{Er}$ & 2.02 & 1.74 & 2.49 & 2.06 & 3.49 & 2.49 & 2.15 & 1.94 & 3.55 \\
\hline $\mathrm{Tm}$ & 0.27 & 0.23 & 0.33 & 0.30 & 0.49 & 0.35 & 0.32 & 0.25 & 0.49 \\
\hline $\mathrm{Yb}$ & 1.76 & 1.47 & 2.12 & 1.95 & 3.14 & 2.26 & 2.12 & 1.61 & 3.12 \\
\hline Lu & 0.28 & 0.21 & 0.30 & 0.28 & 0.47 & 0.33 & 0.31 & 0.24 & 0.47 \\
\hline $\mathrm{Cu}$ & 122.94 & 26.49 & 94.38 & 88.67 & 88 & 115 & 129 & 17 & 46 \\
\hline $\mathrm{Zn}$ & 158.81 & 118.94 & 120.61 & 245.55 & 354 & 166 & 187 & 201 & 224 \\
\hline $\mathrm{Pb}$ & 2.32 & 1.58 & 7.46 & 45.73 & 137.2 & 7.27 & 4.02 & 4.30 & 3.57 \\
\hline $\mathrm{Al}_{2} \mathrm{O}_{3} / \mathrm{TiO}_{2}$ & 4 & 16 & 11 & 19 & 7 & 8 & 17 & 11 & 6 \\
\hline $\mathrm{Nb} / \mathrm{Ta}$ & 17 & 14 & 29 & 17 & 18 & 18 & 16 & 14 & 16 \\
\hline $\mathrm{Zr} / \mathrm{Y}$ & 5.1 & 3.7 & 1.6 & 2.6 & 5.3 & 4.4 & 2.5 & 4.5 & 7.1 \\
\hline $\mathrm{Ti} / \mathrm{Zr}$ & 194 & 122 & 282 & 107 & 68 & 108 & 114 & 109 & 60 \\
\hline Y/Ho & 23 & 24 & 24 & 26 & 26 & 26 & 26 & 25 & 26 \\
\hline $\mathrm{La} / \mathrm{Sm}_{\mathrm{cm}}$ & 1.07 & 0.93 & 2.36 & 1.08 & 1.94 & 1.90 & 1.02 & 1.06 & 1.83 \\
\hline $\mathrm{La} / \mathrm{Yb}_{\mathrm{cn}}$ & 4.12 & 1.98 & 4.82 & 1.10 & 3.28 & 3.14 & 0.97 & 2.18 & 3.37 \\
\hline $\mathrm{Gd} Y \mathrm{Yb}_{\mathrm{cn}}$ & 2.48 & 1.66 & 1.60 & 1.07 & 1.45 & 1.41 & 1.06 & 1.92 & 1.62 \\
\hline $\mathrm{Ce} / \mathrm{Ce}^{*}$ & 1.16 & 1.10 & 1.06 & 1.02 & 1.04 & 1.03 & 1.01 & 1.03 & 1.04 \\
\hline $\mathrm{Eu} / \mathrm{Eu}^{*}$ & 0.67 & 0.60 & 0.62 & 0.83 & 0.87 & 0.95 & 0.96 & 0.87 & 0.96 \\
\hline $\mathrm{Zr} / \mathrm{Zr}^{*}$ & 0.37 & 0.59 & 0.25 & 0.88 & 0.99 & 0.85 & 0.89 & 0.83 & 1.25 \\
\hline $\mathrm{Ti} / \mathrm{Ti}^{*}$ & 1.17 & 0.96 & 0.98 & 0.95 & 0.87 & 1.18 & 0.99 & 1.01 & 0.95 \\
\hline $\mathrm{Nb} / \mathrm{Nb}^{*}$ & 0.22 & 0.19 & 0.09 & 0.12 & 0.15 & 0.11 & 0.27 & 0.41 & 0.23 \\
\hline North & 528315 & 528258 & 528234 & 522085 & 519577 & 519577 & 518907 & 514229 & 514903 \\
\hline East & 5400675 & 5400787 & 5400790 & 5400301 & 5399550 & 5399550 & 5399558 & 5394913 & 5393900 \\
\hline
\end{tabular}


Table 2.1. (Continued)

\begin{tabular}{|c|c|c|c|}
\hline & \multicolumn{3}{|c|}{ Siliciclastic rocks } \\
\hline & BVL2013-014 & BVL2013-015 & BVL2013-016 \\
\hline $\mathrm{SiO}_{2}$ & 73.0 & 66.7 & 64.3 \\
\hline $\mathrm{Al}_{2} \mathrm{O}_{3}$ & 13.2 & 16.2 & 18.6 \\
\hline $\mathrm{Fe}_{2} \mathrm{O}_{3}(\mathrm{~T})$ & 4.5 & 4.8 & 5.3 \\
\hline $\mathrm{MnO}$ & 0.08 & 0.09 & 0.08 \\
\hline $\mathrm{MgO}$ & 0.92 & 0.98 & 0.93 \\
\hline $\mathrm{CaO}$ & 2.06 & 2.85 & 2.58 \\
\hline $\mathrm{Na}_{2} \mathrm{O}$ & 3.52 & 3.52 & 2.63 \\
\hline $\mathrm{K}_{2} \mathrm{O}$ & 2.02 & 3.77 & 4.59 \\
\hline $\mathrm{TiO}_{2}$ & 0.54 & 0.74 & 0.69 \\
\hline $\mathrm{P}_{2} \mathrm{O}_{5}$ & 0.15 & 0.35 & 0.27 \\
\hline LOI & 2.85 & 4.41 & 4.79 \\
\hline Total & 100.3 & 100.6 & 99.4 \\
\hline Mg-number & 29 & 29 & 26 \\
\hline $\mathrm{Cr}$ & 163 & 52 & 190 \\
\hline Co & 19 & 12 & 19 \\
\hline $\mathrm{Ni}$ & 93 & 72 & 118 \\
\hline $\mathrm{Rb}$ & 74 & 116 & 137 \\
\hline $\mathrm{Sr}$ & 227 & 532 & 380 \\
\hline Cs & 2.83 & 3.04 & 4.02 \\
\hline $\mathrm{Ba}$ & 455 & 1172 & 1060 \\
\hline $\mathrm{Sc}$ & 10 & 11 & 13 \\
\hline $\mathrm{V}$ & 87 & 84 & 96 \\
\hline $\mathrm{Ta}$ & 0.266 & 0.672 & 0.728 \\
\hline $\mathrm{Nb}$ & 3.98 & 12.37 & 10.02 \\
\hline $\mathrm{Zr}$ & 119 & 274 & 252 \\
\hline Th & 10.73 & 15.31 & 15.58 \\
\hline $\mathrm{Y}$ & 10.3 & 26.5 & 20.5 \\
\hline $\mathrm{U}$ & 2.03 & 3.31 & 3.50 \\
\hline $\mathrm{La}$ & 33.03 & 76.49 & 65.64 \\
\hline $\mathrm{Ce}$ & 66.26 & 163.97 & 137.62 \\
\hline $\operatorname{Pr}$ & 7.34 & 18.22 & 15.13 \\
\hline $\mathrm{Nd}$ & 27.08 & 66.32 & 54.35 \\
\hline Sm & 4.47 & 10.76 & 8.84 \\
\hline Eu & 1.07 & 2.04 & 1.68 \\
\hline Gd & 3.33 & 7.67 & 5.95 \\
\hline $\mathrm{Tb}$ & 0.41 & 0.97 & 0.77 \\
\hline Dy & 2.04 & 4.96 & 3.88 \\
\hline Ho & 0.38 & 0.94 & 0.73 \\
\hline $\mathrm{Er}$ & 1.18 & 3.07 & 2.41 \\
\hline $\mathrm{Tm}$ & 0.14 & 0.39 & 0.31 \\
\hline $\mathrm{Yb}$ & 0.87 & 2.32 & 1.90 \\
\hline $\mathrm{Lu}$ & 0.14 & 0.38 & 0.31 \\
\hline $\mathrm{Cu}$ & 62 & 22 & 59 \\
\hline $\mathrm{Zn}$ & 206 & 145 & 99 \\
\hline $\mathrm{Pb}$ & 106.4 & 21.5 & 19.2 \\
\hline $\mathrm{Al}_{2} \mathrm{O}_{3} / \mathrm{TiO}_{2}$ & 24 & 22 & 27 \\
\hline $\mathrm{Nb} / \mathrm{Ta}$ & 15 & 18 & 14 \\
\hline $\mathrm{Zr} / \mathrm{Y}$ & 11.6 & 10.3 & 12.3 \\
\hline $\mathrm{Ti} / \mathrm{Zr}$ & 5.3 & 3.1 & 4.0 \\
\hline $\mathrm{Y} / \mathrm{Ho}$ & 27 & 28 & 28 \\
\hline $\mathrm{La} / \mathrm{Sm}_{\mathrm{cn}}$ & 4.8 & 4.6 & 4.8 \\
\hline $\mathrm{La} / \mathrm{Yb}_{\mathrm{cn}}$ & 27.3 & 23.6 & 24.8 \\
\hline $\mathrm{Gd} / \mathrm{Yb}_{\mathrm{cn}}$ & 3.2 & 2.7 & 2.6 \\
\hline $\mathrm{Ce} / \mathrm{Ce}^{*}$ & 1.04 & 1.08 & 1.07 \\
\hline $\mathrm{Eu} / \mathrm{Eu}^{*}$ & 0.85 & 0.69 & 0.71 \\
\hline $\mathrm{Zr} / \mathrm{Zr}^{*}$ & 0.64 & 0.61 & 0.68 \\
\hline $\mathrm{Ti} / \mathrm{Ti}^{*}$ & 0.34 & 0.20 & 0.23 \\
\hline $\mathrm{Nb} / \mathrm{Nb}^{*}$ & 0.05 & 0.08 & 0.07 \\
\hline North & 535952 & 536776 & 536365 \\
\hline East & 5399449 & 5399101 & 5399243 \\
\hline
\end{tabular}


Table 2.2. Major (wt.\%) and trace (ppm) element concentrations and significant element ratios for the Ottertail Lake granite.

\begin{tabular}{|c|c|c|c|c|c|c|c|}
\hline & \multicolumn{5}{|c|}{ Ottertail Lake granite } & \multirow[b]{2}{*}{ BVL2013-061 } & \multirow[b]{2}{*}{ BVL2013-062 } \\
\hline & BVL2013-056 & BVL2013-057 & BVL2013-058 & BVL2013-059 & BVL2013-060 & & \\
\hline $\mathrm{SiO}_{2}$ & 65.5 & 67.0 & 70.0 & 70.6 & 73.5 & 74.2 & 74.8 \\
\hline $\mathrm{Al}_{2} \mathrm{O}_{3}$ & 15.0 & 15.1 & 14.9 & 15.1 & 14.7 & 14.3 & 14.3 \\
\hline $\mathrm{Fe}_{2} \mathrm{O}_{3}(\mathrm{~T})$ & 4.8 & 4.2 & 3.3 & 2.7 & 1.6 & 1.4 & 1.5 \\
\hline $\mathrm{MnO}$ & 0.07 & 0.06 & 0.06 & 0.04 & 0.04 & 0.03 & 0.03 \\
\hline $\mathrm{MgO}$ & 2.42 & 1.96 & 1.14 & 0.94 & 0.33 & 0.22 & 0.21 \\
\hline $\mathrm{CaO}$ & 3.41 & 3.23 & 2.32 & 2.16 & 1.45 & 1.01 & 0.98 \\
\hline $\mathrm{Na}_{2} \mathrm{O}$ & 3.89 & 4.02 & 4.24 & 4.47 & 4.46 & 4.11 & 4.29 \\
\hline $\mathrm{K}_{2} \mathrm{O}$ & 4.19 & 3.77 & 3.58 & 3.57 & 3.74 & 4.55 & 3.71 \\
\hline $\mathrm{TiO}_{2}$ & 0.54 & 0.49 & 0.36 & 0.30 & 0.14 & 0.12 & 0.10 \\
\hline $\mathrm{P}_{2} \mathrm{O}_{5}$ & 0.20 & 0.19 & 0.16 & 0.12 & 0.05 & 0.02 & 0.02 \\
\hline LOI & 0.68 & 0.64 & 0.41 & 0.66 & 0.41 & 0.44 & 0.45 \\
\hline Total & 99.1 & 100.6 & 100.8 & 100.7 & 100.7 & 99.9 & 99.9 \\
\hline Mg-number & 50 & 48 & 41 & 41 & 28 & 24 & 22 \\
\hline $\mathrm{Cr}$ & 86 & 71 & 41 & 24 & 16 & 20 & 10 \\
\hline Co & 13.0 & 11.5 & 7.1 & 5.3 & 2.0 & 1.3 & 1.2 \\
\hline $\mathrm{Ni}$ & 70 & 64 & 38 & 29 & 13 & 11 & 8 \\
\hline $\mathrm{Rb}$ & 101 & 103 & 100 & 96 & 115 & 134 & 100 \\
\hline $\mathrm{Sr}$ & 890 & 977 & 920 & 802 & 628 & 299 & 575 \\
\hline Cs & 1.3 & 2.1 & 3.8 & 1.6 & 2.5 & 5.2 & 2.8 \\
\hline $\mathrm{Ba}$ & 1300 & 1247 & 1190 & 1234 & 1293 & 953 & 1297 \\
\hline Sc & 8.0 & 6.0 & 4.0 & 3.0 & 2.0 & 1.0 & 1.0 \\
\hline V & 65 & 55 & 33 & 25 & 8 & 6 & 4 \\
\hline $\mathrm{Ta}$ & 0.7 & 0.7 & 0.5 & 0.5 & 0.6 & 0.4 & 0.3 \\
\hline $\mathrm{Nb}$ & 9.2 & 8.1 & 5.7 & 5.3 & 5.5 & 4.4 & 3.6 \\
\hline $\mathrm{Zr}$ & 199 & 186 & 150 & 132 & 93 & 90 & 79 \\
\hline Th & 9.4 & 10.3 & 8.6 & 8.4 & 5.4 & 14.5 & 4.6 \\
\hline Y & 17.8 & 15.6 & 12.0 & 10.3 & 8.3 & 7.4 & 7.0 \\
\hline U & 2.1 & 2.1 & 1.9 & 1.1 & 1.9 & 3.0 & 0.8 \\
\hline $\mathrm{La}$ & 51.9 & 46.4 & 38.4 & 33.6 & 18.5 & 37.5 & 21.6 \\
\hline $\mathrm{Ce}$ & 112.6 & 100.7 & 78.9 & 69.1 & 37.1 & 65.5 & 38.9 \\
\hline $\operatorname{Pr}$ & 12.9 & 11.3 & 9.5 & 7.7 & 4.1 & 6.4 & 4.1 \\
\hline $\mathrm{Nd}$ & 47.7 & 40.9 & 35.1 & 28.0 & 14.5 & 20.1 & 13.6 \\
\hline $\mathrm{Sm}$ & 7.7 & 6.4 & 5.6 & 4.4 & 2.4 & 2.8 & 2.2 \\
\hline $\mathrm{Eu}$ & 1.6 & 1.4 & 1.2 & 1.0 & 0.5 & 0.6 & 0.5 \\
\hline Gd & 5.6 & 4.7 & 4.1 & 3.1 & 1.9 & 2.2 & 1.7 \\
\hline $\mathrm{Tb}$ & 0.7 & 0.6 & 0.5 & 0.4 & 0.3 & 0.3 & 0.2 \\
\hline Dy & 3.5 & 3.0 & 2.4 & 1.9 & 1.4 & 1.3 & 1.2 \\
\hline Ho & 0.7 & 0.6 & 0.4 & 0.4 & 0.3 & 0.3 & 0.2 \\
\hline Er & 2.1 & 1.8 & 1.5 & 1.2 & 0.9 & 0.9 & 0.8 \\
\hline $\mathrm{Tm}$ & 0.3 & 0.2 & 0.2 & 0.2 & 0.1 & 0.1 & 0.1 \\
\hline $\mathrm{Yb}$ & 1.6 & 1.4 & 1.1 & 0.9 & 0.9 & 0.8 & 0.8 \\
\hline $\mathrm{Lu}$ & 0.2 & 0.2 & 0.2 & 0.2 & 0.1 & 0.1 & 0.1 \\
\hline $\mathrm{Cu}$ & 17.0 & 14.6 & 6.6 & 5.4 & 5.6 & 3.7 & 3.9 \\
\hline $\mathrm{Zn}$ & 113 & 110 & 93 & 126 & 61 & 66 & 176 \\
\hline $\mathrm{Pb}$ & 20.3 & 19.8 & 17.1 & 15.8 & 21.2 & 27.7 & 23.3 \\
\hline $\mathrm{Al}_{2} \mathrm{O}_{3} / \mathrm{TiO}_{2}$ & 28 & 31 & 42 & 51 & 102 & 124 & 143 \\
\hline $\mathrm{Nb} / \mathrm{Ta}$ & 13 & 12 & 11 & 11 & 9 & 10 & 13 \\
\hline $\mathrm{Zr} / \mathrm{Y}$ & 11.2 & 11.9 & 12.5 & 12.8 & 11.2 & 12.1 & 11.2 \\
\hline Y/Ho & 27.1 & 27.7 & 27.2 & 28.3 & 29.1 & 29.0 & 28.2 \\
\hline $\mathrm{Ti} / \mathrm{Zr}$ & 16 & 16 & 14 & 13 & 9 & 8 & 8 \\
\hline $\mathrm{La} / \mathrm{Sm}_{\mathrm{cn}}$ & 4.4 & 4.7 & 4.5 & 5.0 & 4.9 & 8.6 & 6.5 \\
\hline $\mathrm{La} / \mathrm{Yb}_{\mathrm{cn}}$ & 23.1 & 23.6 & 26.0 & 25.8 & 14.3 & 35.5 & 19.8 \\
\hline $\mathrm{Gd} / \mathrm{Yb}_{\mathrm{cn}}$ & 2.9 & 2.7 & 3.2 & 2.7 & 1.7 & 2.4 & 1.8 \\
\hline $\mathrm{Ce} / \mathrm{Ce}^{*}$ & 1.1 & 1.1 & 1.0 & 1.1 & 1.0 & 1.0 & 1.0 \\
\hline $\mathrm{Eu} / \mathrm{Eu}^{*}$ & 0.7 & 0.8 & 0.8 & 0.8 & 0.8 & 0.8 & 0.8 \\
\hline $\mathrm{Zr} / \mathrm{Zr} *$ & 0.6 & 0.7 & 0.6 & 0.7 & 0.9 & 0.7 & 0.9 \\
\hline $\mathrm{Ti} / \mathrm{Ti} *$ & 0.2 & 0.2 & 0.2 & 0.2 & 0.2 & 0.1 & 0.1 \\
\hline $\mathrm{Nb} / \mathrm{Nb}^{*}$ & 0.10 & 0.09 & 0.07 & 0.07 & 0.13 & 0.04 & 0.09 \\
\hline North & 516902 & 516642 & 515178 & 514355 & 513131 & 512005 & 510582 \\
\hline East & 5399375 & 5399284 & 5399275 & 5399043 & 5398644 & 5398281 & 5397721 \\
\hline
\end{tabular}


Table 2.3. Results of zircon U-Pb isotope analyses

\begin{tabular}{|c|c|c|c|c|c|c|c|c|c|c|c|c|c|c|c|c|}
\hline & \multicolumn{2}{|c|}{ Element concentrations } & \multicolumn{7}{|c|}{ Isotopic ratios } & \multicolumn{7}{|c|}{ Ages(Ma) } \\
\hline & Th (ppm) & $\mathrm{U}(\mathrm{ppm})$ & $\mathrm{Th} / \mathrm{U}$ & ${ }^{207} \mathrm{pb}^{206} \mathrm{~Pb}$ & $\pm 1 \sigma$ & ${ }^{207} \mathrm{~Pb} \mathrm{p}^{235} \mathrm{U}$ & $\pm 1 \sigma$ & ${ }^{206} \mathrm{~Pb}^{238} \mathrm{U}$ & $\pm 1 \sigma$ & ${ }^{207} \mathrm{~Pb} / 206 \mathrm{~Pb}$ & $\pm 1 \sigma^{2}$ & ${ }^{207} \mathrm{pb}^{235} \mathrm{U}$ & $\pm 1 \sigma$ & ${ }^{206} \mathrm{pb}^{238} \mathrm{U}$ & $\pm 1 \sigma$ & Concordance \\
\hline BVL-030-32 & 54 & 81 & 0.66 & 0.1978 & 0.0051 & 15.800 & 0.404 & 0.576 & 0.0070 & 2808 & 24 & 2865 & 24 & 2934 & 28 & $97 \%$ \\
\hline BVL-030-17 & 29 & 49 & 0.58 & 0.1933 & 0.0060 & 14.170 & 0.423 & 0.530 & 0.0082 & 2771 & 27 & 2761 & 28 & 2743 & 34 & $99 \%$ \\
\hline BVL-030-19 & 12 & 28 & 0.43 & 0.1932 & 0.0073 & 14.782 & 0.563 & 0.555 & 0.0089 & 2770 & 38 & 2801 & 36 & 2846 & 37 & $98 \%$ \\
\hline BVL-030-31 & 38 & 64 & 0.59 & 0.1931 & 0.0053 & 14.557 & 0.416 & 0.543 & 0.0066 & 2769 & 29 & 2787 & 27 & 2796 & 28 & $99 \%$ \\
\hline BVL-030-18 & 15 & 34 & 0.44 & 0.1930 & 0.0063 & 14.107 & 0.470 & 0.529 & 0.0085 & 2768 & 31 & 2757 & 32 & 2739 & 36 & $99 \%$ \\
\hline BVL-030-15 & 37 & 63 & 0.60 & 0.1926 & 0.0056 & 15.377 & 0.420 & 0.578 & 0.0071 & 2765 & 27 & 2839 & 26 & 2939 & 29 & $96 \%$ \\
\hline BVL-030-13 & 35 & 70 & 0.49 & 0.1915 & 0.0060 & 15.077 & 0.473 & 0.569 & 0.0063 & 2755 & 34 & 2820 & 30 & 2902 & 26 & $97 \%$ \\
\hline BVL-030-29 & 14 & 32 & 0.45 & 0.1911 & 0.0067 & 15.718 & 0.570 & 0.597 & 0.0123 & 2752 & 31 & 2860 & 35 & 3017 & 50 & $94 \%$ \\
\hline BVL-030-9 & 14 & 33 & 0.42 & 0.1911 & 0.0072 & 15.118 & 0.541 & 0.578 & 0.0100 & 2751 & 34 & 2823 & 34 & 2940 & 41 & $95 \%$ \\
\hline BVL-030-12 & 42 & 71 & 0.59 & 0.1909 & 0.0072 & 15.829 & 0.586 & 0.602 & 0.0106 & 2750 & 35 & 2867 & 35 & 3039 & 43 & $94 \%$ \\
\hline BVL-030-20 & 32 & 56 & 0.57 & 0.1904 & 0.0061 & 15.480 & 0.515 & 0.585 & 0.0084 & 2746 & 33 & 2845 & 32 & 2968 & 34 & $95 \%$ \\
\hline BVL-030-33 & 21 & 40 & 0.52 & 0.1894 & 0.0055 & 14.076 & 0.423 & 0.537 & 0.0071 & 2737 & 30 & 2755 & 29 & 2771 & 30 & $99 \%$ \\
\hline BVL-030-23 & 16 & 36 & 0.43 & 0.1892 & 0.0069 & 14.931 & 0.524 & 0.575 & 0.0082 & 2735 & 36 & 2811 & 33 & 2928 & 34 & $95 \%$ \\
\hline BVL-030-30 & 86 & 102 & 0.84 & 0.1884 & 0.0047 & 15.532 & 0.399 & 0.594 & 0.0069 & 2728 & 25 & 2848 & 25 & 3008 & 28 & $94 \%$ \\
\hline BVL-030-14 & 18 & 39 & 0.45 & 0.1877 & 0.0062 & 14.036 & 0.474 & 0.540 & 0.0074 & 2722 & 35 & 2752 & 32 & 2782 & 31 & $98 \%$ \\
\hline BVL- $030-28$ & 53 & 77 & 0.68 & 0.1877 & 0.0049 & 15.515 & 0.419 & 0.596 & 0.0075 & 2722 & 26 & 2847 & 26 & 3015 & 30 & $94 \%$ \\
\hline BVL-030-16 & 26 & 52 & 0.49 & 0.1873 & 0.0059 & 14.757 & 0.482 & 0.568 & 0.0082 & 2719 & 32 & 2800 & 31 & 2899 & 34 & $96 \%$ \\
\hline BVL-030-3 & 20 & 43 & 0.46 & 0.1862 & 0.0059 & 14.408 & 0.474 & 0.563 & 0.0094 & 2709 & 30 & 2777 & 31 & 2881 & 39 & $96 \%$ \\
\hline BVL-030-21 & 14 & 33 & 0.40 & 0.1861 & 0.0061 & 15.049 & 0.504 & 0.587 & 0.0102 & 2708 & 30 & 2818 & 32 & 2979 & 42 & $94 \%$ \\
\hline BVL-030-11 & 16 & 38 & 0.42 & 0.1860 & 0.0058 & 13.847 & 0.448 & 0.539 & 0.0081 & 2707 & 31 & 2739 & 31 & 2781 & 34 & $98 \%$ \\
\hline BVL-030-7 & 30 & 53 & 0.57 & 0.1857 & 0.0062 & 13.817 & 0.457 & 0.541 & 0.0071 & 2704 & 34 & 2737 & 31 & 2789 & 30 & $98 \%$ \\
\hline BVL-030-2 & 27 & 50 & 0.53 & 0.1855 & 0.0051 & 13.680 & 0.392 & 0.535 & 0.0069 & 2703 & 28 & 2728 & 27 & 2762 & 29 & $98 \%$ \\
\hline BVL-030-22 & 42 & 72 & 0.59 & 0.1855 & 0.0052 & 14.927 & 0.417 & 0.581 & 0.0066 & 2702 & 29 & 2811 & 27 & 2953 & 27 & $95 \%$ \\
\hline BVL-030-10 & 30 & 55 & 0.55 & 0.1851 & 0.0057 & 14.078 & 0.448 & 0.549 & 0.0068 & 2699 & 33 & 2755 & 30 & 2823 & 28 & $97 \%$ \\
\hline BVL-030-25 & 64 & 85 & 0.76 & 0.1848 & 0.0052 & 15.921 & 0.453 & 0.622 & 0.0071 & 2697 & 29 & 2872 & 27 & 3117 & 28 & $91 \%$ \\
\hline BVL-030-27 & 39 & 64 & 0.61 & 0.1846 & 0.0056 & 14.598 & 0.442 & 0.572 & 0.0077 & 2694 & 30 & 2789 & 29 & 2916 & 32 & $95 \%$ \\
\hline BVL-030-26 & 50 & 79 & 0.63 & 0.1843 & 0.0053 & 15.254 & 0.462 & 0.596 & 0.0077 & 2692 & 31 & 2831 & 29 & 3014 & 31 & $93 \%$ \\
\hline BVL-030-8 & 13 & 29 & 0.47 & 0.1841 & 0.0065 & 13.638 & 0.477 & 0.542 & 0.0084 & 2690 & 35 & 2725 & 33 & 2793 & 35 & $97 \%$ \\
\hline BVL-030-4 & 36 & 63 & 0.56 & 0.1834 & 0.0069 & 13.917 & 0.500 & 0.555 & 0.0091 & 2684 & 35 & 2744 & 34 & 2846 & 38 & $96 \%$ \\
\hline BVL-030-1 & 34 & 58 & 0.59 & 0.1832 & 0.0069 & 13.016 & 0.495 & 0.521 & 0.0110 & 2682 & 33 & 2681 & 36 & 2703 & 46 & $99 \%$ \\
\hline BVL-030-24 & 28 & 55 & 0.51 & 0.1831 & 0.0051 & 14.937 & 0.425 & 0.591 & 0.0085 & 2681 & 26 & 2811 & 27 & 2995 & 34 & $93 \%$ \\
\hline BVL-030-5 & 29 & 52 & 0.56 & 0.1805 & 0.0069 & 13.749 & 0.508 & 0.558 & 0.0093 & 2657 & 36 & 2733 & 35 & 2859 & 38 & $95 \%$ \\
\hline BVL-030-6 & 14 & 32 & 0.43 & 0.1719 & 0.0064 & 12.483 & 0.493 & 0.528 & 0.0079 & 2576 & 42 & 2641 & 37 & 2732 & 33 & $96 \%$ \\
\hline
\end{tabular}


Table 2.3. (Continued)

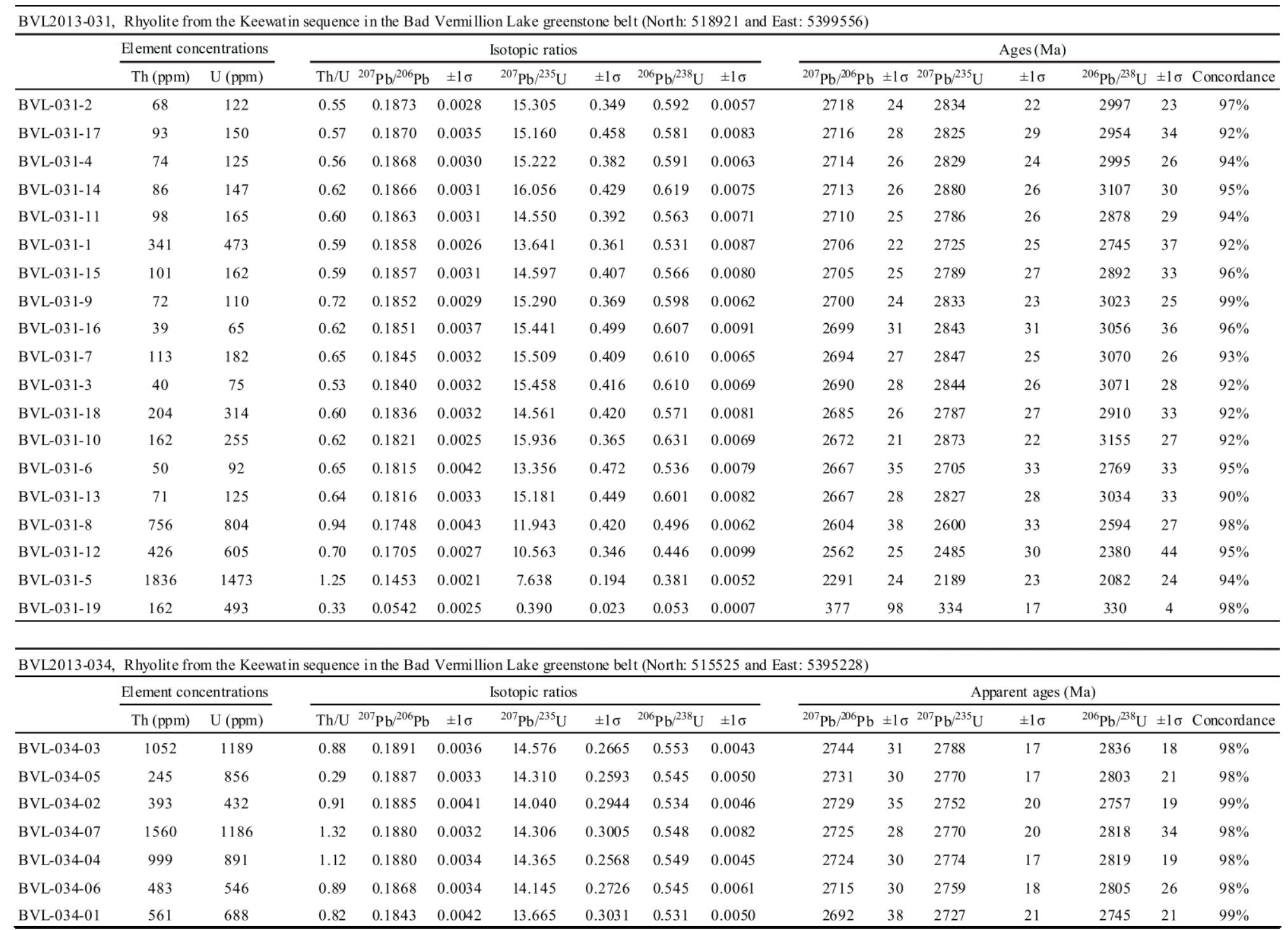


Table 2.3. (Continued)

\begin{tabular}{|c|c|c|c|c|c|c|c|c|c|c|c|c|c|c|c|c|}
\hline & \multicolumn{2}{|c|}{ Element concentrations } & \multicolumn{7}{|c|}{ Isotopic ratios } & \multicolumn{7}{|c|}{ Ages (Ma) } \\
\hline & Th (ppm) & $\mathrm{U}(\mathrm{ppm})$ & $\mathrm{Th} / \mathrm{U}$ & ${ }^{207} \mathrm{~Pb} /{ }^{206} \mathrm{~Pb}$ & $\pm 1 \sigma$ & ${ }^{207} \mathrm{~Pb} /{ }^{235} \mathrm{U}$ & $\pm 1 \sigma$ & ${ }^{206} \mathrm{~Pb} /{ }^{238} \mathrm{U}$ & $\pm 1 \sigma$ & ${ }^{207} \mathrm{~Pb} /{ }^{206} \mathrm{~Pb}$ & $\pm 1 \sigma$ & ${ }^{207} \mathrm{~Pb} /{ }^{235} \mathrm{U}$ & $\pm 1 \sigma$ & ${ }^{206} \mathrm{~Pb} /{ }^{238} \mathrm{U}$ & $\pm 1 \sigma$ & Concordance \\
\hline BVL-058-10 & 179 & 259 & 0.69 & 0.205 & 0.0051 & 15.479 & 0.5623 & 0.531 & 0.0090 & 2868 & 41 & 2845 & 35 & 2744 & 38 & $96 \%$ \\
\hline BVL-058-04 & 171 & 208 & 0.82 & 0.182 & 0.0040 & 12.658 & 0.2778 & 0.505 & 0.0052 & 2733 & 36 & 2655 & 21 & 2634 & 22 & $99 \%$ \\
\hline BVL-058-13 & 235 & 221 & 1.06 & 0.183 & 0.0046 & 13.435 & 0.3448 & 0.530 & 0.0061 & 2681 & 41 & 2711 & 24 & 2741 & 26 & $98 \%$ \\
\hline BVL-058-03 & 301 & 392 & 0.77 & 0.183 & 0.0036 & 13.217 & 0.2718 & 0.521 & 0.0053 & 2680 & 32 & 2695 & 19 & 2705 & 22 & $99 \%$ \\
\hline BVL-058-02 & 350 & 507 & 0.69 & 0.182 & 0.0034 & 13.119 & 0.2489 & 0.519 & 0.0048 & 2674 & 32 & 2688 & 18 & 2696 & 21 & $99 \%$ \\
\hline BVL-058-07 & 202 & 239 & 0.84 & 0.182 & 0.0041 & 13.321 & 0.3061 & 0.529 & 0.0055 & 2674 & 38 & 2703 & 22 & 2737 & 23 & $98 \%$ \\
\hline BVL-058-19 & 477 & 680 & 0.70 & 0.182 & 0.0037 & 12.683 & 0.2478 & 0.500 & 0.0043 & 2668 & 33 & 2656 & 18 & 2615 & 19 & $98 \%$ \\
\hline BVL-058-18 & 204 & 279 & 0.73 & 0.181 & 0.0039 & 13.244 & 0.2760 & 0.524 & 0.0045 & 2666 & 35 & 2697 & 20 & 2715 & 19 & $99 \%$ \\
\hline BVL-058-05 & 424 & 569 & 0.74 & 0.181 & 0.0037 & 13.000 & 0.2732 & 0.518 & 0.0050 & 2665 & 35 & 2680 & 20 & 2692 & 21 & $99 \%$ \\
\hline BVL-058-06 & 269 & 238 & 1.13 & 0.181 & 0.0043 & 13.072 & 0.3118 & 0.523 & 0.0055 & 2661 & 39 & 2685 & 23 & 2712 & 23 & $99 \%$ \\
\hline BVL-058-20 & 436 & 572 & 0.76 & 0.181 & 0.0040 & 13.286 & 0.2805 & 0.526 & 0.0045 & 2661 & 32 & 2700 & 20 & 2726 & 19 & $99 \%$ \\
\hline BVL-058-09 & 468 & 574 & 0.81 & 0.180 & 0.0034 & 12.541 & 0.2399 & 0.502 & 0.0043 & 2655 & 31 & 2646 & 18 & 2623 & 19 & $99 \%$ \\
\hline BVL-058-11 & 252 & 368 & 0.69 & 0.180 & 0.0036 & 12.965 & 0.2722 & 0.520 & 0.0055 & 2655 & 33 & 2677 & 20 & 2697 & 23 & $99 \%$ \\
\hline BVL-058-15 & 420 & 517 & 0.81 & 0.180 & 0.0038 & 13.068 & 0.2834 & 0.522 & 0.0055 & 2655 & 34 & 2685 & 21 & 2709 & 23 & $99 \%$ \\
\hline BVL-058-12 & 281 & 307 & 0.91 & 0.179 & 0.0039 & 12.812 & 0.2905 & 0.515 & 0.0052 & 2648 & 36 & 2666 & 21 & 2679 & 22 & $99 \%$ \\
\hline BVL-058-08 & 463 & 494 & 0.94 & 0.179 & 0.0037 & 11.619 & 0.2572 & 0.471 & 0.0062 & 2643 & 34 & 2574 & 21 & 2486 & 27 & $96 \%$ \\
\hline BVL-058-14 & 423 & 559 & 0.76 & 0.179 & 0.0041 & 12.862 & 0.3008 & 0.518 & 0.0050 & 2643 & 37 & 2670 & 22 & 2689 & 21 & $99 \%$ \\
\hline BVL-058-16 & 238 & 295 & 0.81 & 0.177 & 0.0035 & 12.530 & 0.2693 & 0.509 & 0.0057 & 2633 & 32 & 2645 & 20 & 2652 & 24 & $99 \%$ \\
\hline
\end{tabular}


Table 2.4. Sm-Nd isotope composition of the volcanic rocks and gabbros in the Neoarchean Bad Vermillion Lake greenstone belt.

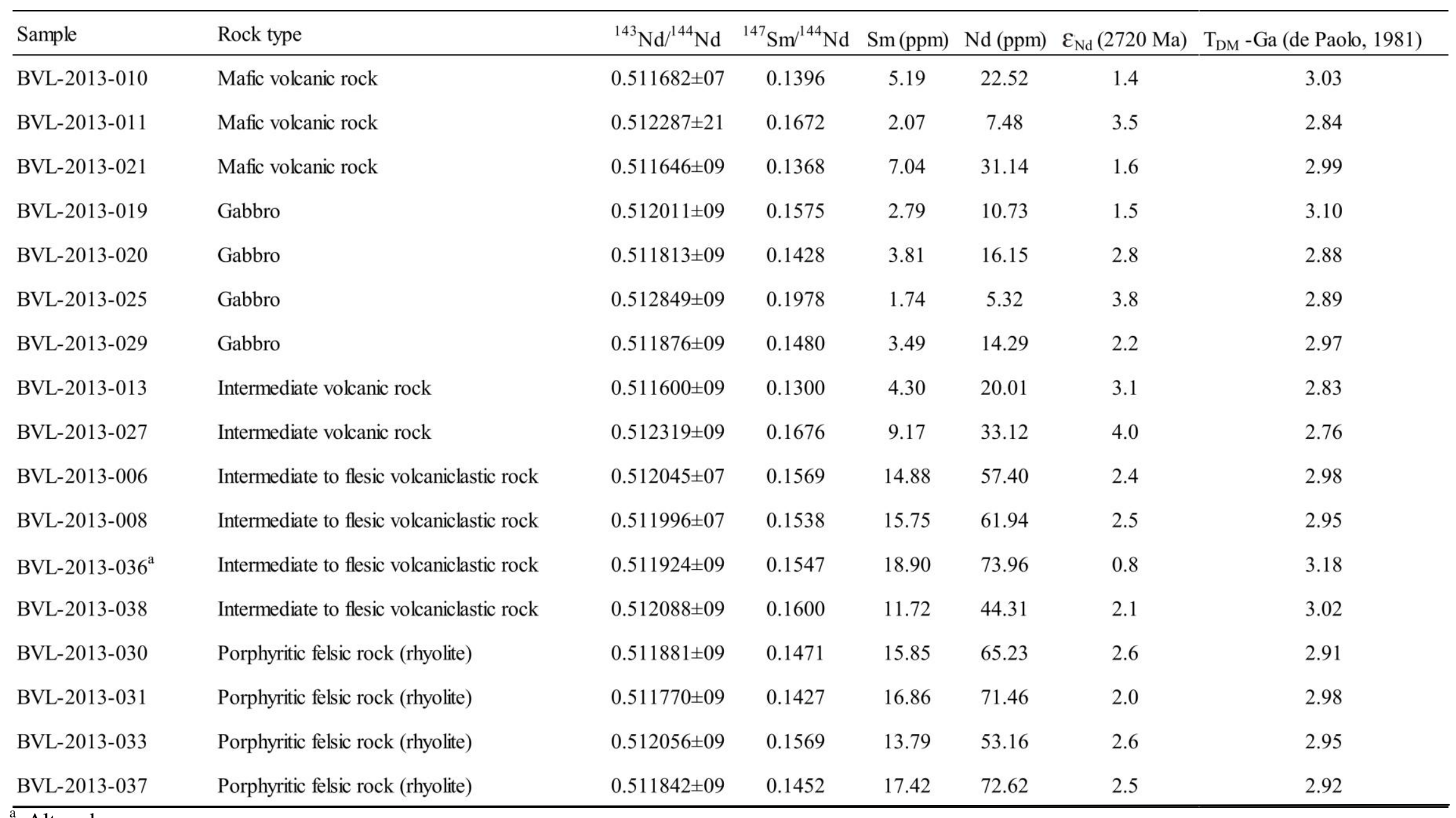

a : Altered 
Table 2.5. Pb isotope compositions of the volcanic rocks and gabbros in the Neoarchean Bad Vermillion Lake greenstone belt.

\begin{tabular}{|c|c|c|c|c|c|c|c|c|}
\hline Sample & Rock type & ${ }^{206} \mathrm{~Pb} /{ }^{204} \mathrm{~Pb}$ & $\pm 2 \mathrm{~s}$ & ${ }^{207} \mathrm{~Pb} /{ }^{204} \mathrm{~Pb}$ & $\pm 2 \mathrm{~s}$ & ${ }^{208} \mathrm{~Pb} /{ }^{204} \mathrm{~Pb}$ & $\pm 2 \mathrm{~s}$ & $\mathrm{U}$ (ppm) \\
\hline BVL-2013-010 & Mafic volcanic rock & 16.595 & 0.009 & 15.094 & 0.010 & 35.772 & 0.029 & 0.507 \\
\hline BVL-2013-011 & Mafic volcanic rock & 18.609 & 0.015 & 15.551 & 0.014 & 39.195 & 0.040 & 0.069 \\
\hline BVL-2013-021 & Mafic volcanic rock & 23.076 & 0.028 & 16.274 & 0.021 & 43.486 & 0.059 & 0.645 \\
\hline BVL-2013-019 & Gabbro & 26.607 & 0.033 & 17.013 & 0.022 & 40.250 & 0.055 & 0.332 \\
\hline BVL-2013-020 & Gabbro & 27.295 & 0.026 & 17.146 & 0.018 & 39.020 & 0.047 & 0.416 \\
\hline BVL-2013-025 & Gabbro & 13.805 & 0.013 & 14.660 & 0.015 & 33.655 & 0.038 & 0.065 \\
\hline BVL-2013-029 & Gabbro & 29.472 & 0.034 & 17.608 & 0.021 & 51.296 & 0.067 & 0.272 \\
\hline BVL-2013-013 & Intermediate volcanic rock & 20.263 & 0.012 & 15.754 & 0.011 & 39.531 & 0.033 & 4.846 \\
\hline BVL-2013-027 & Intermediate volcanic rock & 17.623 & 0.018 & 15.392 & 0.017 & 38.695 & 0.046 & 0.493 \\
\hline BVL-2013-006 & Intermediate to felsic volcaniclastic rock & 45.258 & 0.031 & 20.339 & 0.016 & 64.815 & 0.058 & 1.537 \\
\hline BVL-2013-008 & Intermediate to felsic volcaniclastic rock & 20.374 & 0.011 & 15.780 & 0.010 & 40.357 & 0.031 & 1.410 \\
\hline BVL-2013-036 $6^{\mathrm{a}}$ & Intermediate to felsic volcaniclastic rock & 36.157 & 0.024 & 18.858 & 0.014 & 55.270 & 0.050 & 2.222 \\
\hline BVL-2013-038 & Intermediate to felsic volcaniclastic rock & 41.164 & 0.033 & 19.774 & 0.018 & 64.600 & 0.065 & 1.131 \\
\hline BVL-2013-030 & Porphyritic felsic rock (rhyolite) & 60.672 & 0.037 & 23.404 & 0.017 & 85.100 & 0.070 & 1.997 \\
\hline BVL-2013-031 & Porphyritic felsic rock (rhyolite) & 35.985 & 0.025 & 18.556 & 0.015 & 57.772 & 0.052 & 2.165 \\
\hline BVL-2013-033 & Porphyritic felsic rock (rhyolite) & 14.405 & 0.008 & 14.753 & 0.010 & 34.430 & 0.030 & 1.329 \\
\hline BVL-2013-037 & Porphyritic felsic rock (rhyolite) & 54.948 & 0.041 & 21.568 & 0.018 & 75.369 & 0.074 & 2.130 \\
\hline
\end{tabular}


Table 2.6. Rb-Sr isotope compositions of the volcanic rocks and gabbros in the Neoarche an Bad Vermillion Lake greenstone belt.

\begin{tabular}{|c|c|c|c|c|c|}
\hline Sample & Rock type & ${ }^{87} \mathrm{Sr} /{ }^{86} \mathrm{Sr}$ & $\mathrm{Rb}$ & $\mathrm{Sr}$ & ${ }^{87} \mathrm{Rb} /{ }^{86} \mathrm{Sr}$ \\
\hline BVL-2013-010 & Mafic volcanic rock & $0.716155 \pm 09$ & 16.27 & 114.50 & 0.410 \\
\hline BVL-2013-011 & Mafic volcanic rock & $0.701512 \pm 09$ & 0.38 & 89.88 & 0.012 \\
\hline BVL-2013-021 & Mafic volcanic rock & $0.730744 \pm 09$ & 30.48 & 107.50 & 0.819 \\
\hline BVL-2013-019 & Gabbro & $0.704741 \pm 24$ & 1.37 & 41.41 & 0.095 \\
\hline BVL-2013-020 & Gabbro & $0701481 \pm 10$ & 1.04 & 153.82 & 0.020 \\
\hline BVL-2013-025 & Gabbro & $0.701896 \pm 07$ & 1.26 & 159.87 & 0.023 \\
\hline BVL-2013-029 & Gabbro & $0.705468 \pm 08$ & 7.09 & 182.33 & 0.112 \\
\hline BVL-2013-013 & Intermediate volcanic rock & $0.724386 \pm 09$ & 4.91 & 193.95 & 0.073 \\
\hline BVL-2013-027 & Intermediate volcanic rock & $0.724179 \pm 13$ & 4.63 & 20.38 & 0.657 \\
\hline BVL-2013-006 & Intermediate to felsic volcaniclastic rock & $0.759619 \pm 09$ & 19.43 & 34.29 & 1.637 \\
\hline BVL-2013-008 & Intermediate to felsic volcaniclastic rock & $0.840242 \pm 10$ & 41.16 & 31.58 & 3.765 \\
\hline BVL-2013-036 ${ }^{\mathrm{a}}$ & Intermediate to felsic volcaniclastic rock & $0.940511 \pm 11$ & 93.19 & 39.38 & 6.836 \\
\hline BVL-2013-038 & Intermediate to felsic volcaniclastic rock & $0.722065 \pm 12$ & 10.41 & 43.20 & 0.696 \\
\hline BVL-2013-030 & Porphyritic felsic rock (rhyolite) & $0.837695 \pm 10$ & 39.27 & 19.53 & 5.807 \\
\hline BVL-2013-031 & Porphyritic felsic rock (rhyolite) & $0.913308 \pm 09$ & 69.98 & 55.41 & 3.648 \\
\hline BVL-2013-033 & Porphyritic felsic rock (rhyolite) & $0.732422 \pm 09$ & 19.75 & 67.45 & 0.846 \\
\hline BVL-2013-037 & Porphyritic felsic rock (rhyolite) & $1.011538 \pm 12$ & 52.39 & 15.44 & 9.799 \\
\hline
\end{tabular}

${ }^{\mathrm{a}}$ : Altered 


\section{CHARPTER 3}

\section{Conclusions, Implications and Suggestions for future studies}

\subsection{Conclusions and implications}

This thesis is mainly aimed to define the geology of the BVL greenstone belt on the basis of previous pioneers' work and newly acquired geochemical and geochronological data. Based on these resources, we can basically restore the petrogenetic and geodynamic processes of the BVL greenstone belt and associated granitic intrusions. The following conclusions are considered to be the major contribution to this thesis project:

(1) The BVL greenstone belt is made up of bimodal tholeiitic to calc-alkaline basalts to rhyolite association, gabbros, and Seine group siliciclastic rocks. The greenstone belt was intruded by diachronous granitic intrusions.

(2) The BVL greenstone belt originated from partial melting of subarc mantle wedge, showing an affinity with subduction-related ophiolite.

(3) The Ottertail Lake granitic magma was produced by partial melting of preexisting Laurentian granitoid and Seine Group sedimentary rocks in a syncollisional arc setting. The intrusion was later emplaced in an extensional basin.

(4) In the context of regional tectonics, the BVL greenstone belt and associated layered anorthosite complex were generated at around ca. 2.5 Ga, which was caused by the northerly subduction processes underneath the west Wabigoon terrane and Marmion terrane. The emplacement of Ottertail Lake granite at ca. 2.64 Ga marks the end of the major collision among the Wabigoon, Marmion, and Quetico and Abitibi-Wawa terrane. 


\subsection{Implications}

Alteration can be caused by a series of geological processes such as sea-floor hydrothermal activities, regional metamorphism and late granitic intrusions (Polat et al., 2003, 2007; Terabayashi et al., 2003; Weiershauser and Spooner, 2005; OrdóñezCalderón et al., 2008). Although the BVL greenstone belt experienced low-grade greenschist metamorphism, it still suffers significant hydrothermal alteration. Because of the alteration, some primary mineralogy and textures in the BVL greenstone volcanic rocks have been obscured. In that case, only $\mathrm{Ce}$ anomalies on chondritenormalized diagram and carbonate-quartz enrichment (Polat and Hoffman, 2003) can be employed as alteration standards. In addition, the $\mathrm{Nd}, \mathrm{Sr}, \mathrm{Pb}$ isochrons have been used to examine the alteration of the greenstone samples. It is fortunate to see most samples still preserves trace element patterns that resemble those of unaltered Phanerozoic counterparts. The trace element patterns can help us to discriminate various geodynamic environments related to the greenstone formations.

The integrated studies of the BVL greenstone belt and associated layered intrusions imply the existence of magmatic arcs in the Neoarchean Era. This conclusion supports the operation of subduction processes in the Archean. Although komatiites have been found in Steep Rock-Lumby Lake area in the west Wabigoon terrane, it is still a rare volcanic sequence and corresponds to a short interval of basement generation and crustal rifting (Hollings and Wyman, 1999). Above all, it is convincing that horizontal motions of plate tectonics are the dominant force to shape early Earth (Eriksson et al., 2004; Kerrich and Polat, 2006; Polat et al., 2015).

\subsection{Suggestions for future studies}

Recommendations for further study of the BVL greenstone belt and associated 
granitic rocks are made as follows:

(1) Greenstone belts are exceptional host rocks for nickel sulphide, volcanogenic massive sulphide $\mathrm{Cu}-\mathrm{Zn}-\mathrm{Pb}$ (VMS), lode gold, iron formation and some other deposits (Condie, 1981; Herrington et al., 1997), it is advisable to make a detailed study of the resource potential of ore deposits in the BVL greenstone belts

(2) Savant-Sturgeon and Finlayson greenstone belts in the west Wabigoon subprovince also show arc affinities (Sanborn-Barrie and Skulski, 2006; Backeberg et al., 2014). Comparative studies between the BVL greenstone belt and these greenstone belts may significantly contribute to the reconstruction of geodynamic processes of Western Superior Province.

(3) The $\mathrm{Nd}, \mathrm{Pb}$, and $\mathrm{Sr}$ isotopic systems shed light on the source characteristics of the BVL greenstone belt. Prevalent hydrothermal alterations have made the interpretation of the $\mathrm{Nd}, \mathrm{Pb}$ and $\mathrm{Sr}$ data a little more complicated. Hf in the zircon are exceptionally immobile, so it is suggested to incorporate zircon Hf isotopic data to the whole rock $\mathrm{Sm}-\mathrm{Nd}$ and $\mathrm{Rb}-\mathrm{Sr}$ systems to distinguish juvenile mantle from older crustal sources (Patchett, 1983).

\subsection{References}

Condie, K.C., 1981. Archaean greenstone belts. In: Windley, B.F. (Ed.), Elsevier scientific publishing company, Amsterdam, Netherlands, pp. 1-44.

Eriksson, P.G., Catuneanu, O. Nelson, D.R., Mueller, W.U., Alterman, W., 2004. Towards a synthesis. In: Eriksson, P.G., Altermann, W., Nelson, D.R., Mueller, W.U., Catuneanu, O., (Eds.). The Precambrian Earth: Tempos and Events. Developments in Precambrian Geology 12, 739-769.

Herrington, R.J., Evans, D.M., Buchaman, D.L., 1997. Metallogenic Aspects. In de Wit, M.J., Ashwal, L.D. (Eds.), Greenstone Belts. Oxford University Press, 
Oxford, pp. 176-219,

Kerrich, R., Polat, A., 2006. Archean greenstone-tonalite duality: thermochemical mantle convection models or plate tectonics in the early Earth global dynamics? Tectonophysics 415, 141-165.

Ordóñez-Calderón, J.C., Polat, A., Fryer, B.J., Gagnon, J.E., Raith, J.G., Appel, P.W.U., 2008. Evidence for HFSE and REE mobility during calc-silicate metasomatism, Mesoarchean ( $3075 \mathrm{Ma})$ Ivisaartoq greenstone belt, southern West Greenland. Precambrian Research 161(3-4), 317-340.

Patchett, P.J., 1983. Importance of the Lu-Hf isotopic system in studies of planetary chronology and chemical evolution. Geochemica et Cosmochimica Acta 47, 8191.

Polat, A., Hofmann, A.W., Münker, C., Regelous, M., Appel, P.W.U., 2003. Contrasting geochemical patterns in the 3.7-3.8 Ga pillow basalt cores and rims, Isua greenstone belt, Southwest Greenland: implications for post-magmatic alteration processes. Geochimica et Cosmochimica Acta 67 (3), 441-457.

Polat, A., Appel, P.W.U., Frei, R., Pan, Y., Dilek, Y., Ordóñez-Calderón J.C., Fryer, B., Hollis, J.A., Raith, J.G., 2007. Field and Geochemical Characteristics of the Mesoarchean ( 3075 Ma) Ivisaartoq greenstone belt, southern West Greenland: Evidence for sea floor hydrothermal alteration in suprasubduction oceanic crust. Gondwana Research 11, 69-91.

Polat, A., Wang, L., Appel, P.W.U., 2015. A review of structural patterns and melting processes in the Archean craton of West Greenland: Evidence for crustal growth at convergent plate margins as opposed to non-uniformitarian models (in press).

Terabayashi, M., Masada, Y., Ozawa, H., 2003. Archean ocean-floor metamorphism in the North Pole area, Pilbara Craton, Western Australia. Precambrian Research 127, 167-180.

Weiershäuser, L., Spooner, E.T.C., 2005. Seafloor hydrothermal fluids, Ben Nevis area, Abitibi greenstone belt; implications for Archean (approximately $2.7 \mathrm{Ga}$ ) seawater properties. Precambrian Research 138, 89-123. 


\section{Appendix A: Supplementary Data Table 1}

Supplementary Data Table 1 Measured and recommended trace element concentrations for the standard samples (BHVO-1 and BIR-1)

\begin{tabular}{|c|c|c|c|c|c|c|c|c|}
\hline \multirow{2}{*}{ Element } & \multicolumn{4}{|c|}{ BIR } & \multicolumn{4}{|c|}{ BHVO-1 } \\
\hline & Measured $(n=1)$ & Recommended & Reference & Deviation $(\%)$ & Measured $(n=1)$ & Recommended & Reference & Deviation (\%) \\
\hline $\mathrm{Cr}$ & 364.55 & 370 & $\mathrm{a}$ & 1.47 & 260.94 & 289 & $\mathrm{a}$ & 9.71 \\
\hline $\mathrm{Co}$ & 52.33 & 52 & a & 0.63 & 46.57 & 45 & a & 3.48 \\
\hline $\mathrm{Ni}$ & 219.26 & 170 & $\mathrm{a}$ & 28.98 & 273.88 & 120 & a & 128.23 \\
\hline $\mathrm{Rb}$ & 0.22 & 0.24 & a & 7.30 & 8.90 & 9.5 & $\mathrm{a}$ & 6.30 \\
\hline $\mathrm{Sr}$ & 101.93 & 110 & $\mathrm{~b}$ & 7.34 & 441.10 & 403 & $\mathrm{~b}$ & 9.45 \\
\hline Cs & 0.006 & 0.005 & $\mathrm{~b}$ & 11.99 & 0.10 & 0.10 & $\mathrm{a}$ & 3.10 \\
\hline $\mathrm{Ba}$ & 8.48 & 7.00 & b & 21.14 & 138.11 & 139 & b & 0.64 \\
\hline V & 316.34 & 313 & b & 1.07 & 304.11 & 317 & b & 4.07 \\
\hline $\mathrm{Ta}$ & 0.04 & 0.06 & $\mathrm{~b}$ & 32.42 & 0.89 & 1.20 & b & 26.19 \\
\hline $\mathrm{Nb}$ & 0.50 & 0.55 & b & 9.06 & 12.43 & 19 & $\mathrm{~b}$ & 34.58 \\
\hline $\mathrm{Zr}$ & 12.71 & 14.50 & $\mathrm{a}$ & 12.35 & 141.21 & 179 & b & 21.11 \\
\hline $\mathrm{Hf}$ & 0.57 & 0.56 & a & 1.03 & 3.92 & 4.4 & b & 10.91 \\
\hline $\mathrm{Th}$ & 0.11 & 0.300 & a & 62.45 & 1.22 & 1.1 & b & 10.60 \\
\hline $\mathrm{Y}$ & 13.38 & 16 & b & 16.35 & 22.50 & 28 & b & 19.64 \\
\hline $\mathrm{U}$ & 0.01 & 0.01 & a & 10.38 & 0.40 & 0.42 & $\mathrm{a}$ & 4.29 \\
\hline $\mathrm{La}$ & 0.57 & 0.58 & $\mathrm{a}$ & 1.14 & 14.41 & 16.00 & b & 9.94 \\
\hline $\mathrm{Ce}$ & 1.80 & 1.85 & $\mathrm{a}$ & 2.55 & 36.04 & 39.00 & b & 7.60 \\
\hline $\operatorname{Pr}$ & 0.36 & 0.37 & $\mathrm{a}$ & 3.75 & 5.07 & 5.45 & $\mathrm{a}$ & 6.90 \\
\hline $\mathrm{Nd}$ & 2.18 & 2.35 & $\mathrm{a}$ & 7.33 & 23.17 & 25.00 & b & 7.34 \\
\hline $\mathrm{Sm}$ & 1.04 & 1.10 & $\mathrm{a}$ & 5.90 & 5.80 & 6.20 & b & 6.40 \\
\hline $\mathrm{Eu}$ & 0.49 & 0.52 & $\mathrm{a}$ & 5.51 & 1.95 & 2.06 & b & 5.13 \\
\hline Gd & 1.89 & 1.97 & $\mathrm{a}$ & 3.83 & 6.16 & 6.40 & b & 3.72 \\
\hline $\mathrm{Tb}$ & 0.34 & 0.38 & $\mathrm{a}$ & 10.95 & 0.89 & 0.96 & b & 7.40 \\
\hline Dy & 2.42 & 2.50 & $\mathrm{a}$ & 3.30 & 5.00 & 5.20 & b & 3.89 \\
\hline Ho & 0.53 & 0.57 & $\mathrm{a}$ & 7.11 & 0.92 & 0.99 & b & 7.40 \\
\hline $\mathrm{Er}$ & 1.59 & 1.70 & $\mathrm{a}$ & 6.70 & 2.49 & 2.42 & b & 2.92 \\
\hline $\mathrm{Tm}$ & 0.23 & 0.24 & a & 3.51 & 0.30 & 0.33 & b & 8.74 \\
\hline $\mathrm{Yb}$ & 1.54 & 1.60 & $\mathrm{a}$ & 3.99 & 1.83 & 2.00 & b & 8.62 \\
\hline $\mathrm{Lu}$ & 0.23 & 0.25 & $\mathrm{a}$ & 7.10 & 0.26 & 0.29 & b & 11.74 \\
\hline $\mathrm{Cu}$ & 119.51 & 125 & b & 4.39 & 149.80 & 136 & $\mathrm{a}$ & 10.15 \\
\hline $\mathrm{Zn}$ & 124.36 & 70 & b & 77.66 & 174.82 & 105 & b & 66.50 \\
\hline $\mathrm{Pb}$ & 6.64 & 3 & $\mathrm{~b}$ & 121.28 & 6.51 & 2.6 & $\mathrm{~b}$ & 150.40 \\
\hline
\end{tabular}

For the reference, a denotes that the recommended values are from the Geochemical Reference

Materials and Certificates of the United States Geological Survey in 2002; b denotes the values are based on Eggins et al. (1997). 
Appendix B: Supplementary Data Table 2

Supplementary Data Table 2. Measured element concentration data in analyzed zircons from the rhyolite sample BVL2013-030, BVL2013-031, BVL2013034 and the Ottertail Lake granite sample BVL2013-058

\begin{tabular}{|c|c|c|c|c|c|c|c|c|c|c|c|c|c|c|}
\hline \multicolumn{15}{|c|}{ Sample BVL2013-030. } \\
\hline Spot No. & 1 & 2 & 3 & 4 & 5 & 6 & 7 & 8 & 9 & 10 & 11 & 12 & 13 & 14 \\
\hline${ }^{29} \mathrm{SiO}_{2}$ & 32.7 & 32.7 & 32.7 & 32.7 & 32.7 & 32.7 & 32.7 & 32.7 & 32.7 & 32.7 & 32.7 & 32.7 & 32.7 & 32.7 \\
\hline${ }^{49} \mathrm{Ti}$ & 21.0 & 25.3 & 23.0 & 27.2 & 7.1 & 24.8 & 50.4 & 19. 7 & 9.8 & 7.7 & 28.0 & 31.4 & 11.8 & 25.9 \\
\hline${ }^{89} \mathrm{Y}$ & 2497 & 1427 & 1066 & 1181 & 1193 & 951 & 1529 & 1136 & 822 & 2156 & 921 & 1336 & 1308 & 1094 \\
\hline${ }^{93} \mathrm{Nb}$ & 1.9 & 1.9 & 2.2 & 1.5 & 1.6 & 1.8 & 2.6 & 1.5 & 2.2 & 1.9 & 2.1 & 3.5 & 6.3 & 2.1 \\
\hline${ }^{139} \mathrm{La}$ & 1.8 & 0.2 & 0.1 & 0.0 & 0.4 & 0.4 & 0.0 & 0.0 & 0.0 & 0.1 & 0.0 & 0.1 & 0.0 & 0.0 \\
\hline${ }^{140} \mathrm{Ce}$ & 8.8 & 3.2 & 3.3 & 3. 6 & 3.8 & 3. 6 & 3.5 & 2.4 & 2.7 & 3.5 & 2.7 & 4.5 & 7. 9 & 3.1 \\
\hline${ }^{141} \mathrm{Pr}$ & 1. 0 & 0.1 & 0.0 & 0.0 & 0.1 & 0.2 & 0.1 & 0.1 & 0.0 & 0.3 & 0.1 & 0.3 & 0.0 & 0.0 \\
\hline${ }^{146} \mathrm{Nd}$ & 7.2 & 1.2 & 1.5 & 0.0 & 1.1 & 1. 4 & 1.9 & 2.0 & 1.1 & 2.5 & 0.6 & 1. 6 & 0.6 & 1.5 \\
\hline${ }^{147} \mathrm{Sm}$ & 8.9 & 4.4 & 0.9 & 2.5 & 4.0 & 1.5 & 3.9 & 2.0 & 0.9 & 5.2 & 1.9 & 2. 7 & 1. 8 & 3.1 \\
\hline${ }^{151} \mathrm{Eu}$ & 2.2 & 0.9 & 0.8 & 0.3 & 0.7 & 1. 0 & 1. 0 & 0.9 & 0.2 & 1.2 & 0.7 & 0.7 & 0.7 & 0.6 \\
\hline${ }^{157} \mathrm{Gd}$ & 56 & 28 & 21 & 24 & 22 & 19 & 27 & 23 & 14 & 45 & 16 & 24 & 22 & 20 \\
\hline${ }^{159} \mathrm{~Tb}$ & 18 & 10 & 7 & 8 & 8 & 6 & 11 & 8 & 5 & 16 & 6 & 9 & 8 & 7 \\
\hline${ }^{163} \mathrm{Dy}$ & 230 & 123 & 93 & 102 & 104 & 84 & 140 & 105 & 70 & 198 & 80 & 119 & 117 & 100 \\
\hline${ }^{165} \mathrm{Ho}$ & 85 & 48 & 35 & 39 & 40 & 33 & 52 & 38 & 27 & 72 & 31 & 43 & 45 & 37 \\
\hline${ }^{166} \mathrm{Er}$ & 362 & 219 & 166 & 183 & 183 & 149 & 230 & 176 & 133 & 326 & 145 & 207 & 204 & 172 \\
\hline${ }^{169} \mathrm{Tm}$ & 74 & 46 & 35 & 39 & 39 & 32 & 49 & 37 & 27 & 66 & 32 & 43 & 43 & 37 \\
\hline${ }^{172} \mathrm{Yb}$ & 643 & 434 & 336 & 363 & 370 & 305 & 462 & 357 & 271 & 611 & 323 & 425 & 415 & 370 \\
\hline${ }^{178} \mathrm{Hf}$ & 7852 & 8097 & 7886 & 6251 & 7423 & 8569 & 7747 & 7961 & 7684 & 7648 & 8185 & 6524 & 8959 & 8140 \\
\hline${ }^{181} \mathrm{Ta}$ & 0.8 & 1.1 & 1. 0 & 1. 0 & 0.7 & 1.1 & 1.2 & 0.7 & 0.9 & 0.9 & 1. 0 & 1. 7 & 2.8 & 0.9 \\
\hline${ }^{204} \mathrm{~Pb}$ & 631 & 164 & 23 & 147 & 0 & 438 & 223 & 0 & 11 & 0 & 132 & 0 & 0 & 0 \\
\hline${ }^{206} \mathrm{~Pb}$ & 79 & 68 & 60 & 91 & 75 & 41 & 73 & 39 & 47 & 75 & 50 & 105 & 97 & 51 \\
\hline${ }^{207} \mathrm{~Pb}$ & 63 & 56 & 50 & 74 & 60 & 32 & 60 & 32 & 39 & 60 & 39 & 85 & 77 & 40 \\
\hline${ }^{208} \mathrm{~Pb}$ & 149 & 121 & 95 & 191 & 141 & 56 & 127 & 61 & 65 & 134 & 81 & 249 & 158 & 84 \\
\hline $\mathrm{Pb}_{\text {Total }}$ & 120 & 94 & 76 & 141 & 105 & 52 & 101 & 48 & 54 & 102 & 65 & 174 & 123 & 65 \\
\hline${ }^{232} \mathrm{Th}$ & 34 & 27 & 20 & 36 & 29 & 14 & 30 & 13 & 14 & 30 & 16 & 42 & 35 & 18 \\
\hline${ }^{238} \mathrm{U}$ & 58 & 50 & 43 & 63 & 52 & 32 & 53 & 29 & 33 & 55 & 38 & 71 & 70 & 39 \\
\hline$\Sigma$ REE & 1612 & 994 & 760 & 827 & 842 & 688 & 1059 & 809 & 599 & 1442 & 690 & 948 & 933 & 810 \\
\hline
\end{tabular}


Supplementary Data Table 1. (Continued)

\begin{tabular}{|c|c|c|c|c|c|c|c|c|c|c|c|c|c|c|c|}
\hline \multicolumn{16}{|c|}{ Sample BVL2013-030. } \\
\hline Spot No. & 17 & 18 & 19 & 20 & 21 & 22 & 23 & 24 & 25 & 26 & 27 & 28 & 29 & 30 & 31 \\
\hline${ }^{29} \mathrm{SiO}_{2}$ & 32.7 & 32.7 & 32.7 & 32.7 & 32.7 & 32.7 & 32.7 & 32.7 & 32.7 & 32.7 & 32.7 & 32.7 & 32.7 & 32.7 & 32.7 \\
\hline${ }^{49} \mathrm{Ti}$ & 9.0 & 5.6 & 5.1 & 13.5 & 28.0 & 4.3 & 32.2 & 16.5 & 0.0 & 0.0 & 14.6 & 11.7 & 22.4 & 18. 8 & 9.1 \\
\hline${ }^{89} \mathrm{Y}$ & 2043 & 912 & 946 & 1512 & 803 & 1317 & 898 & 1446 & 1539 & 3201 & 2451 & 1490 & 898 & 1862 & 2678 \\
\hline${ }^{93} \mathrm{Nb}$ & 1.4 & 2.1 & 1. 8 & 3.3 & 1.3 & 3.1 & 1.4 & 2.9 & 4.5 & 2.2 & 2.2 & 2.9 & 2.5 & 4.6 & 2. 0 \\
\hline${ }^{139} \mathrm{La}$ & 0.0 & 0.0 & 0.0 & 74.9 & 0.0 & 0.0 & 0.1 & 0.0 & 0.0 & 0.0 & 0.0 & 0.0 & 0.2 & 0.0 & 0.1 \\
\hline${ }^{140} \mathrm{Ce}$ & 3.5 & 2.3 & 2.7 & 224.0 & 2.8 & 5.1 & 2.7 & 4.4 & 5.4 & 3.7 & 3.7 & 4.2 & 2.9 & 6.3 & 4. 3 \\
\hline${ }^{141} \mathrm{Pr}$ & 0.1 & 0.1 & 0.2 & 34.6 & 0.1 & 0.0 & 0.1 & 0.4 & 0.1 & 0.1 & 0.1 & 0.1 & 0.0 & 0.0 & 0.1 \\
\hline${ }^{146} \mathrm{Nd}$ & 4. 0 & 0.0 & 0.5 & 221.8 & 1.1 & 1. 4 & 0.4 & 2. 4 & 1. 0 & 5.3 & 2.9 & 1.8 & 2.3 & 1.0 & 2.8 \\
\hline${ }^{147} \mathrm{Sm}$ & 7. 6 & 2.2 & 2. 8 & 67.9 & 1. 1 & 3. 7 & 1.5 & 3.5 & 4. 0 & 9.9 & 7.5 & 4.6 & 1.9 & 4.4 & 7. 4 \\
\hline${ }^{151} \mathrm{Eu}$ & 1.8 & 0.6 & 0.7 & 7. 8 & 0.5 & 0.7 & 0.4 & 0.4 & 0.9 & 2. 5 & 1.4 & 0.9 & 0.5 & 0.6 & 1. 3 \\
\hline${ }^{157} \mathrm{Gd}$ & 46 & 15 & 15 & 107 & 14 & 25 & 15 & 27 & 27 & 72 & 53 & 30 & 14 & 34 & 59 \\
\hline${ }^{159} \mathrm{~Tb}$ & 16 & 6 & 6 & 19 & 5 & 9 & 5 & 10 & 10 & 24 & 18 & 9 & 5 & 12 & 20 \\
\hline${ }^{163} \mathrm{Dy}$ & 195 & 82 & 79 & 168 & 69 & 112 & 77 & 123 & 134 & 294 & 225 & 131 & 73 & 163 & 244 \\
\hline${ }^{165} \mathrm{Ho}$ & 70 & 30 & 32 & 52 & 27 & 44 & 29 & 48 & 52 & 109 & 83 & 49 & 29 & 62 & 91 \\
\hline${ }^{166} \mathrm{Er}$ & 304 & 143 & 144 & 212 & 125 & 207 & 139 & 218 & 231 & 477 & 362 & 221 & 136 & 283 & 401 \\
\hline${ }^{169} \mathrm{Tm}$ & 62 & 31 & 31 & 42 & 27 & 43 & 29 & 46 & 49 & 97 & 74 & 47 & 29 & 56 & 80 \\
\hline${ }^{172} \mathrm{Yb}$ & 600 & 310 & 311 & 414 & 275 & 420 & 301 & 451 & 470 & 884 & 692 & 463 & 288 & 553 & 744 \\
\hline${ }^{175} \mathrm{Lu}$ & 92 & 51 & 50 & 63 & 44 & 68 & 49 & 74 & 77 & 142 & 115 & 77 & 51 & 93 & 119 \\
\hline${ }^{178} \mathrm{Hf}$ & 8476 & 8732 & 7977 & 6990 & 7152 & 7122 & 7432 & 7717 & 7440 & 7485 & 7806 & 7031 & 8312 & 7305 & 8757 \\
\hline${ }^{181} \mathrm{Ta}$ & 0.7 & 0.9 & 1. 0 & 1.2 & 1.0 & 1.3 & 0.8 & 0.9 & 1.4 & 1.2 & 1.2 & 1.1 & 0.8 & 1.7 & 1. 0 \\
\hline${ }^{204} \mathrm{~Pb}$ & 34 & 0 & 0 & 17 & 81 & 178 & 0 & 0 & 0 & 78 & 218 & 0 & 72 & 98 & 0 \\
\hline${ }^{206} \mathrm{~Pb}$ & 63 & 43 & 37 & 79 & 46 & 102 & 50 & 77 & 125 & 110 & 86 & 109 & 45 & 143 & 82 \\
\hline${ }^{207} \mathrm{~Pb}$ & 51 & 35 & 30 & 64 & 37 & 80 & 40 & 62 & 102 & 89 & 69 & 88 & 37 & 115 & 67 \\
\hline${ }^{208} \mathrm{~Pb}$ & 114 & 66 & 55 & 153 & 65 & 209 & 73 & 139 & 321 & 228 & 169 & 253 & 61 & 396 & 155 \\
\hline $\mathrm{Pb}_{\text {Total }}$ & 87 & 52 & 44 & 114 & 54 & 154 & 59 & 105 & 221 & 167 & 128 & 178 & 52 & 269 & 116 \\
\hline${ }^{232} \mathrm{Th}$ & 29 & 15 & 12 & 32 & 14 & 42 & 16 & 28 & 64 & 50 & 39 & 53 & 14 & 86 & 38 \\
\hline${ }^{238} \mathrm{U}$ & 49 & 34 & 28 & 56 & 33 & 72 & 36 & 55 & 85 & 79 & 64 & 77 & 32 & 102 & 64 \\
\hline$\Sigma$ REE & 1401 & 673 & 677 & 1708 & 593 & 938 & 650 & 1007 & 1061 & 2121 & 1638 & 1040 & 632 & 1270 & 1773 \\
\hline
\end{tabular}


Supplementary Data Table 2. (Continued)

\begin{tabular}{|c|c|c|c|c|c|c|c|c|c|c|c|c|c|c|c|c|c|}
\hline \multicolumn{18}{|c|}{ Sample BVL2013-031 } \\
\hline Spot No. & 1 & 2 & 3 & 4 & 5 & 6 & 7 & 8 & 9 & 10 & 11 & 12 & 13 & 14 & 15 & 16 & 17 \\
\hline${ }^{29} \mathrm{SiO}_{2}$ & 32.7 & 32.7 & 32.7 & 32.7 & 32.7 & 32.7 & 32.7 & 32.7 & 32.7 & 32.7 & 32.7 & 32.7 & 32.7 & 32.7 & 32.7 & 32.7 & 32.7 \\
\hline${ }^{49} \mathrm{Ti}$ & 0.0 & 24.5 & 0.0 & 39.5 & 166.7 & 15.3 & 1.4 & 3.0 & 3.9 & 12.1 & 58.4 & 3089.4 & 23.1 & 23.0 & 21.4 & 30.1 & 9.7 \\
\hline${ }^{89} \mathrm{Y}$ & 7104 & 1997 & 2467 & 2485 & 23296 & 1535 & 2998 & 12725 & 2986 & 3818 & 3279 & 3776 & 2226 & 2599 & 3037 & 1389 & 2249 \\
\hline${ }^{93} \mathrm{Nb}$ & 21.3 & 8.3 & 2.3 & 6.7 & 366.7 & 3.1 & 10.2 & 31.9 & 6.6 & 8.7 & 7.3 & 322.5 & 4.9 & 6.1 & 5.9 & 4.7 & 10.0 \\
\hline${ }^{139} \mathrm{La}$ & 0.0 & 0.0 & 0.0 & 0.0 & 122.4 & 0.8 & 0.9 & 0.9 & 318.0 & 0.1 & 0.0 & 31.8 & 19.3 & 0.0 & 0.7 & 59.1 & 0.5 \\
\hline${ }^{140} \mathrm{Ce}$ & 34.8 & 8.1 & 3. 4 & 6.9 & 548.5 & 7.9 & 13.8 & 97.8 & 880.1 & 15.5 & 8.5 & 97.0 & 52.3 & 11.1 & 13.7 & 149.7 & 10.8 \\
\hline${ }^{141} \mathrm{Pr}$ & 0.4 & 0.0 & 0.1 & 0.4 & 41.8 & 0.8 & 0.0 & 2.2 & 138.2 & 0.2 & 0.0 & 11.7 & 7. 1 & 0.2 & 0.6 & 21.7 & 0.2 \\
\hline${ }^{146} \mathrm{Nd}$ & 9.2 & 2.0 & 2.9 & 2.9 & 236.8 & 3.4 & 3. 8 & 28.6 & 812.1 & 7.4 & 4.5 & 66.3 & 41.2 & 2.6 & 5.4 & 122.0 & 5.9 \\
\hline${ }^{147} \mathrm{Sm}$ & 18.5 & 4. 5 & 6.9 & 7. 3 & 142.6 & 5.7 & 7. 2 & 46. 7 & 256.2 & 12.8 & 9.2 & 47.9 & 16.5 & 8.1 & 11.9 & 35.0 & 9.3 \\
\hline${ }^{151} \mathrm{Eu}$ & 2.6 & 0.6 & 2.5 & 0.8 & 9.5 & 0.4 & 0.8 & 4.4 & 16.5 & 1.5 & 2.1 & 20.0 & 2.0 & 0.8 & 2.2 & 2.8 & 0.9 \\
\hline${ }^{157} \mathrm{Gd}$ & 140 & 34 & 52 & 49 & 455 & 30 & 54 & 296 & 339 & 70 & 63 & 187 & 57 & 47 & 69 & 55 & 44 \\
\hline${ }^{159} \mathrm{~Tb}$ & 48 & 13 & 18 & 17 & 154 & 10 & 20 & 99 & 57 & 26 & 22 & 62 & 16 & 18 & 24 & 12 & 16 \\
\hline${ }^{163} \mathrm{Dy}$ & 636 & 167 & 230 & 216 & 2012 & 134 & 270 & 1198 & 424 & 339 & 283 & 621 & 196 & 230 & 295 & 141 & 202 \\
\hline${ }^{165} \mathrm{Ho}$ & 235 & 65 & 83 & 82 & 749 & 49 & 99 & 436 & 105 & 127 & 109 & 159 & 75 & 88 & 105 & 47 & 76 \\
\hline${ }^{166} \mathrm{Er}$ & 1055 & 306 & 368 & 377 & 3463 & 238 & 457 & 1899 & 375 & 577 & 495 & 556 & 338 & 397 & 455 & 207 & 347 \\
\hline${ }^{169} \mathrm{Tm}$ & 203 & 64 & 73 & 75 & 715 & 50 & 91 & 363 & 65 & 116 & 99 & 115 & 69 & 80 & 90 & 42 & 69 \\
\hline${ }^{172} \mathrm{Yb}$ & 1819 & 594 & 675 & 698 & 6519 & 466 & 860 & 3082 & 570 & 1079 & 917 & 1227 & 654 & 772 & 836 & 405 & 653 \\
\hline${ }^{175} \mathrm{Lu}$ & 299 & 102 & 114 & 120 & 986 & 78 & 142 & 494 & 86 & 171 & 157 & 210 & 106 & 120 & 131 & 66 & 107 \\
\hline${ }^{178} \mathrm{Hf}$ & 8276 & 9019 & 7206 & 8139 & 7463 & 8152 & 8426 & 8162 & 8547 & 8002 & 8234 & 15947 & 8258 & 8403 & 8161 & 6806 & 7377 \\
\hline${ }^{181} \mathrm{Ta}$ & 5.7 & 3.1 & 1.5 & 2.5 & 14.6 & 2.4 & 3.7 & 6.5 & 2.8 & 3.5 & 3.0 & 274.1 & 2.1 & 2.3 & 2.0 & 1.1 & 2. 8 \\
\hline${ }^{204} \mathrm{~Pb}$ & 4 & 0 & 3 & 80 & 0 & 28 & 0 & 108 & 48 & 32 & 31 & 0 & 110 & 0 & 121 & 0 & 0 \\
\hline${ }^{206} \mathrm{~Pb}$ & 677 & 180 & 115 & 188 & 1495 & 123 & 283 & 1022 & 164 & 412 & 239 & 748 & 196 & 231 & 245 & 102 & 233 \\
\hline${ }^{207} \mathrm{~Pb}$ & 486 & 131 & 82 & 136 & 849 & 88 & 205 & 725 & 120 & 294 & 173 & 495 & 138 & 166 & 173 & 72 & 170 \\
\hline${ }^{208} \mathrm{~Pb}$ & 1808 & 358 & 221 & 411 & 4223 & 234 & 664 & 3515 & 392 & 1024 & 515 & 1243 & 423 & 524 & 570 & 250 & 579 \\
\hline $\mathrm{Pb}_{\text {Total }}$ & 1218 & 260 & 162 & 292 & 2761 & 172 & 461 & 2250 & 272 & 701 & 366 & 941 & 301 & 367 & 398 & 172 & 397 \\
\hline${ }^{232} \mathrm{Th}$ & 341 & 68 & 40 & 74 & 1836 & 50 & 113 & 756 & 72 & 162 & 98 & 426 & 71 & 86 & 101 & 39 & 93 \\
\hline${ }^{238} \mathrm{U}$ & 473 & 122 & 75 & 125 & 1473 & 92 & 182 & 804 & 110 & 255 & 165 & 605 & 125 & 147 & 162 & 65 & 150 \\
\hline$\Sigma$ REE & 4500 & 1359 & 1628 & 1653 & 16155 & 1074 & 2019 & 8046 & 4442 & 2542 & 2168 & 3411 & 1649 & 1774 & 2040 & 1366 & 1540 \\
\hline
\end{tabular}


Supplementary Data Table 2. (Continued)

\begin{tabular}{|c|c|c|c|c|c|c|c|}
\hline \multicolumn{8}{|c|}{ Sample BVL2013-034. } \\
\hline Spot No. & 1 & 2 & 3 & 4 & 5 & 6 & 7 \\
\hline${ }^{29} \mathrm{SiO}_{2}$ & 93.6 & 94.7 & 91.9 & 93.2 & 95.2 & 93.2 & 89.2 \\
\hline${ }^{49} \mathrm{Ti}$ & 290.3 & 20.9 & 162.8 & 269.8 & 13.8 & 110.2 & 218.9 \\
\hline${ }^{89} \mathrm{Y}$ & 11556 & 9199 & 15610 & 12348 & 3361 & 15237 & 29468 \\
\hline${ }^{93} \mathrm{Nb}$ & 55.0 & 27.0 & 120.0 & 90.0 & 179.9 & 28.1 & 81.4 \\
\hline${ }^{139} \mathrm{La}$ & 11.7 & 0.2 & 2.6 & 3.6 & 0.3 & 0.3 & 1.2 \\
\hline${ }^{140} \mathrm{Ce}$ & 98.5 & 40.1 & 187.5 & 94.9 & 24.0 & 60.7 & 187.3 \\
\hline${ }^{141} \mathrm{Pr}$ & 6.6 & 0.4 & 2.8 & 2.2 & 0.1 & 1.3 & 2.5 \\
\hline${ }^{146} \mathrm{Nd}$ & 52.3 & 8.8 & 25.2 & 19.2 & 2.5 & 18.9 & 34.1 \\
\hline${ }^{147} \mathrm{Sm}$ & 53.3 & 24.3 & 45.7 & 33.1 & 3.5 & 43.9 & 69.0 \\
\hline${ }^{151} \mathrm{Eu}$ & 22.3 & 4.9 & 9.2 & 10.0 & 0.7 & 7.0 & 7.7 \\
\hline${ }^{157} \mathrm{Gd}$ & 241 & 169 & 309 & 223 & 33 & 323 & 467 \\
\hline${ }^{159} \mathrm{~Tb}$ & 81 & 59 & 109 & 77 & 14 & 109 & 167 \\
\hline${ }^{163}$ Dy & 1035 & 796 & 1414 & 1039 & 210 & 1395 & 2251 \\
\hline${ }^{165} \mathrm{Ho}$ & 367 & 294 & 495 & 385 & 92 & 497 & 829 \\
\hline${ }^{166} \mathrm{Er}$ & 1659 & 1361 & 2222 & 1817 & 538 & 2223 & 3743 \\
\hline${ }^{169} \mathrm{Tm}$ & 308 & 256 & 403 & 351 & 130 & 404 & 680 \\
\hline${ }^{172} \mathrm{Yb}$ & 2995 & 2460 & 3730 & 3412 & 1533 & 3763 & 6254 \\
\hline${ }^{175} \mathrm{Lu}$ & 471 & 386 & 538 & 534 & 256 & 562 & 886 \\
\hline${ }^{178} \mathrm{Hf}$ & 28674 & 25876 & 32491 & 27842 & 29883 & 27549 & 31298 \\
\hline${ }^{181} \mathrm{Ta}$ & 28.2 & 9.9 & 34.3 & 30.0 & 256.4 & 8.5 & 19.4 \\
\hline $\mathrm{Pb}_{\text {common }}$ & 70 & 0 & 0 & 14 & 5 & 27 & 5 \\
\hline $\mathrm{Pb}_{\text {Total }}$ & 1778 & 1130 & 3243 & 2679 & 1073 & 1575 & 4545 \\
\hline${ }^{232} \mathrm{Th}$ & 561 & 393 & 1052 & 999 & 245 & 483 & 1560 \\
\hline${ }^{238} \mathrm{U}$ & 688 & 432 & 1189 & 891 & 856 & 546 & 1186 \\
\hline$\Sigma$ REE & 7401 & 5861 & 9492 & 8002 & 2836 & 9410 & 15578 \\
\hline
\end{tabular}


Supplementary Data Table 2. (Continued)

\begin{tabular}{|c|c|c|c|c|c|c|c|c|c|c|c|c|c|c|c|c|c|}
\hline \multicolumn{18}{|c|}{ Sample BVL2013-058. } \\
\hline Spot No. & 1 & 2 & 3 & 4 & 5 & 6 & 7 & 8 & 9 & 10 & 11 & 12 & 13 & 14 & 15 & 16 & 17 \\
\hline${ }^{29} \mathrm{SiO}_{2}$ & 95.8 & 94.8 & 95.1 & 95.8 & 95.0 & 95.6 & 95.5 & 94.6 & 94.8 & 95.2 & 95.3 & 95.3 & 96.0 & 94.9 & 94.9 & 95.0 & 94.8 \\
\hline${ }^{49} \mathrm{Ti}$ & 62.9 & 18.2 & 12.0 & 36.5 & 6.1 & 27.5 & 50.2 & 39.9 & 22.1 & 256.8 & 58.4 & 16.8 & 53.7 & 24.6 & 26.3 & 27.1 & 14.8 \\
\hline${ }^{89} \mathrm{Y}$ & 1415 & 1591 & 1306 & 1659 & 1860 & 2759 & 1740 & 3371 & 2535 & 1340 & 1280 & 1859 & 2450 & 1718 & 2330 & 1548 & 2008 \\
\hline${ }^{93} \mathrm{Nb}$ & 3.5 & 4.7 & 3. 1 & 3. 2 & 5.2 & 2.6 & 2.4 & 6.5 & 7.9 & 4. 6 & 4.4 & 3.7 & 2.3 & 5.5 & 6.3 & 4.7 & 7.1 \\
\hline${ }^{139} \mathrm{La}$ & 0.7 & 1.5 & 0.1 & 0.9 & 0.3 & 0.2 & 4.4 & 143.4 & 0.0 & 9.6 & 0.4 & 40.3 & 0.1 & 69.9 & 11.6 & 0.1 & 0.2 \\
\hline${ }^{140} \mathrm{Ce}$ & 126.6 & 143.2 & 89.7 & 78.6 & 121.7 & 78.1 & 103.2 & 454.7 & 151.6 & 185.9 & 90.7 & 187.4 & 71.7 & 249.0 & 205.9 & 79.9 & 151.6 \\
\hline${ }^{141} \mathrm{Pr}$ & 1.3 & 1.7 & 0.2 & 0.9 & 0.0 & 0.6 & 2.5 & 38.0 & 0.5 & 3.1 & 0.2 & 11.4 & 0.6 & 11.7 & 9.3 & 0.1 & 0.4 \\
\hline${ }^{146} \mathrm{Nd}$ & 10.8 & 13.1 & 2.4 & 7.5 & 3.0 & 12.6 & 21.4 & 170.9 & 4. 2 & 19. 8 & 2. 3 & 47.4 & 11.3 & 42.5 & 57.8 & 2.9 & 3.8 \\
\hline${ }^{147} \mathrm{Sm}$ & 11.4 & 8.9 & 4. 6 & 8.7 & 5.8 & 18.1 & 12.1 & 48.3 & 11.9 & 9.2 & 3.2 & 14.1 & 15.8 & 11.2 & 31.5 & 7.9 & 6.9 \\
\hline${ }^{151} \mathrm{Eu}$ & 2.7 & 3.1 & 1.3 & 2.4 & 2.2 & 4. 3 & 3.3 & 10.2 & 2. 3 & 3. 7 & 1.1 & 2.3 & 4. 2 & 3.0 & 10.6 & 1.2 & 1.8 \\
\hline${ }^{157} \mathrm{Gd}$ & 36.5 & 30.2 & 26.7 & 37.0 & 29.5 & 75.0 & 45.3 & 101.1 & 47. 6 & 32.3 & 22.6 & 41.9 & 67.8 & 32.3 & 71.0 & 34.9 & 36.6 \\
\hline${ }^{159} \mathrm{~Tb}$ & 10 & 9 & 8 & 11 & 10 & 20 & 12 & 26 & 15 & 8 & 7 & 12 & 18 & 9 & 18 & 10 & 11 \\
\hline${ }^{163} \mathrm{Dy}$ & 117 & 110 & 92 & 139 & 131 & 228 & 133 & 278 & 184 & 99 & 93 & 145 & 207 & 119 & 195 & 116 & 135 \\
\hline${ }^{165} \mathrm{Ho}$ & 40 & 44 & 36 & 49 & 49 & 80 & 50 & 95 & 71 & 37 & 36 & 52 & 69 & 45 & 66 & 44 & 54 \\
\hline${ }^{166} \mathrm{Er}$ & 193 & 235 & 188 & 231 & 270 & 384 & 244 & 470 & 361 & 189 & 189 & 262 & 338 & 251 & 324 & 221 & 295 \\
\hline${ }^{169} \mathrm{Tm}$ & 41 & 53 & 42 & 48 & 62 & 78 & 53 & 99 & 81 & 41 & 42 & 55 & 70 & 57 & 68 & 48 & 68 \\
\hline${ }^{172} \mathrm{Yb}$ & 445 & 666 & 490 & 542 & 747 & 822 & 567 & 1082 & 921 & 474 & 479 & 615 & 749 & 702 & 762 & 529 & 826 \\
\hline${ }^{178} \mathrm{Hf}$ & 31397 & 37256 & 36182 & 31246 & 35153 & 30494 & 32857 & 34979 & 35066 & 35644 & 35071 & 34054 & 27618 & 35996 & 34758 & 37173 & 35226 \\
\hline${ }^{181} \mathrm{Ta}$ & 1.3 & 2.0 & 1.5 & 1.2 & 2.1 & 1.2 & 1. 4 & 2.3 & 3. 1 & 1.5 & 1.8 & 1.9 & 1.2 & 1.8 & 2.7 & 1.9 & 2.5 \\
\hline $\mathrm{Pb}_{\text {common }}$ & 0 & 0 & 39 & 0 & 33 & 0 & 60 & 20 & 10 & 69 & 54 & 41 & 73 & 19 & 0 & 60 & 0 \\
\hline $\mathrm{Pb}_{\text {Total }}$ & 439 & 1054 & 856 & 475 & 1251 & 736 & 622 & 1217 & 1346 & 727 & 806 & 794 & 660 & 1272 & 1294 & 682 & 1620 \\
\hline${ }^{232} \mathrm{Th}$ & 167 & 350 & 301 & 171 & 424 & 269 & 202 & 463 & 468 & 179 & 252 & 281 & 235 & 423 & 420 & 238 & 557 \\
\hline${ }^{238} \mathrm{U}$ & 178 & 507 & 392 & 208 & 569 & 238 & 239 & 494 & 574 & 259 & 368 & 307 & 221 & 559 & 517 & 295 & 702 \\
\hline$\Sigma$ REE & 1117 & 1452 & 1078 & 1257 & 1585 & 1948 & 1357 & 3212 & 2024 & 1200 & 1059 & 1600 & 1762 & 1742 & 1969 & 1191 & 1751 \\
\hline
\end{tabular}




\section{Vita Auctoris}

Tuoyu Wu was born in June 1987 in Qianjiang, Hubei Province, China. He did his undergraduate studies in a joint program between China University of Geosciences and University of Waterloo, and acquired bachelor degree from both sides in 2010 and 2011 respectively. In September 2013, he moved on to the University of Windsor, where he started his M.Sc. and is currently a master candidate. He hopes to graduate in August 2015. 